\title{
Is There Hope for Change? The Evolution of Conceptions of “Good” Corporate Governance ${ }^{\dagger}$
}

LYNNE L. DALLAS*

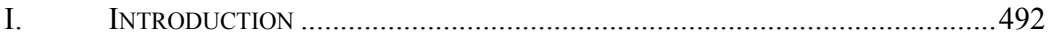

II. EARLY CONCEPTIONS OF “GOOD” CORPORATE GOVERNANCE .....................497

A. Cooperation Among and Acquisition of Competitors ......................497

B. Manufacturing and the Unitary, Functional Form of

Organization

C. Marketing and Sales and the Multidivisional Form of Organization

III. MODERN CONCEPTIONS OF "GOOD” CORPORATE

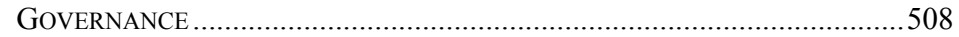

A. The Portfolio Conception and Conglomerates....................................508

B. The Origins of the Shareholder Value Maximization Conception and a Retrospective Analysis of Conglomerates

C. The Emergence of the Shareholder Value Maximization Conception and Disaggregation

$\dagger \quad$ (C) 2017 Lynne L. Dallas.

Professor of Law, University of San Diego School of Law; Harvard Law School, J.D. (1975). I am grateful for helpful comments on this Article from June Carbone, John Whiteclay Chambers II, Gerald F. Davis, Jeff Schwartz, Faith Stevelman, Harwell Wells, and participants at the 2016-2017 Washington \& Lee University School of Law Symposium, Corporate Law, Governance, and Purpose: A Tribute to Professors Lyman Johnson and David Millon. I am also thankful for the research assistance of USD law students, Nima Michel Astani and Seth Skolnik, and reference librarians at the USD Pardee Legal Research Center, Jane Larrington, Ruth Levor, Michele Knapp, Anna Russell, Melissa Abernathy, Christine Mathias, and Dan Kimmons. I am also appreciative of the editorial assistance of San Diego Law Review editors Preston Bennett, Michelle Ganotis, Evan Critchlow, and Lily Duong. 
IV. CONSEQuences of THE Shareholder VAlue MaXimization

CONCEPTION AND THE EMERGENCE OF THE SUSTAINABILITY

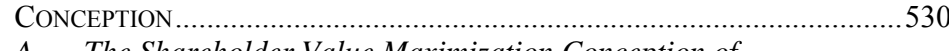

A. The Shareholder Value Maximization Conception of

"Good” Corporate Governance ..................................................530

1. Firm Purpose ....................................................................530

2. Meeting or Beating Quarterly Earnings Expectations ...............531

3. Executive Compensation.......................................................533

4. The Cognitive and Motivational Context for Managerial Decision Making ...............................................................554

5. Short-Term Equity Traders ...................................................538

6. Financial Scandals of the Early 2000s .....................................539

7. Hedge Fund Activism.................................................................541

8. Large Payouts to Shareholders: A Change in Orientation from "Retain and Reinvest" to

"Downsize and Distribute"? ...................................................554

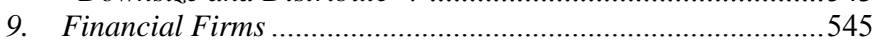

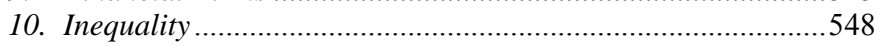

B. The Sustainability Conception of "Good" Corporate

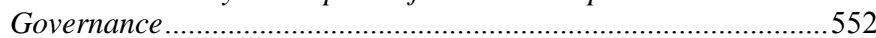

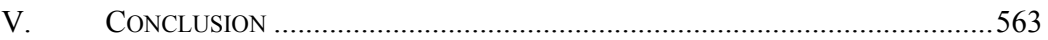

\section{INTRODUCTION}

To provide a useful perspective on corporate governance today, this Article examines the evolution of conceptions of "good" corporate governance that have successively revolutionized the corporate landscape. ${ }^{1}$ By the use of "evolution," I do not mean some natural evolution, but changes in the beliefs of managers concerning how to run their businesses effectively. ${ }^{2}$ "Good" corporate governance refers to what is perceived as good from the point of view of firm managers and may or may not translate into what is good for society. ${ }^{3}$

This Article shows that corporate decision making was influenced over the years by successive, rationalized ideals of good corporate governance. ${ }^{4}$

1. See Neil Fligstein \& Linda Markowitz, Financial Reorganization of American Corporations in the 1980s, in Sociology AND THE PuBlic AGENDA 185, 192 (William Julius Wilson ed., 1993) (defining conceptions as "worldviews held by managers that define what appropriate and inappropriate responses to situations are").

2. The term "managers" used in this Article refers to both directors and officers of firms.

3. See Neil Fligstein, The Transformation of Corporate Control 18-20 (1990) [hereinafter Fligstein, THE TRANSFormation OF CORPORATE CONTROL].

4. Dirk M. Zorn, Here a Chief, There a Chief: The Rise of the CFO in the American Firm, 69 AM. Soc. REV. 345, 346, 348 (2004); see Neil Fligstein, The Structural Transformation of American Industry: An Institutional Account of the Causes of Diversification in the 
Changes in conceptions were precipitated by crises and environmental changes. ${ }^{5}$ They were reasoned, if often flawed, responses to complex macroeconomic forces, competitive conditions, regulations or the lack thereof, and other environmental factors. ${ }^{6}$ More importantly, they were reflections of the culture and thinking of the time, influenced by the views of successful business leaders, the business press, investors, and academics. ${ }^{7}$

Industries' practices and practices in their own firms also influenced managers. ${ }^{8}$ Moreover, their backgrounds, for example in manufacturing or finance, influenced their perceptions of the problems confronting their firms, the perceived causes of the problems, and how to respond to them. ${ }^{9}$ Additionally, once structures and strategies became generally accepted, firms were more likely to adopt them and less likely to abandon them even if the circumstances initially causing their adoption no longer existed. ${ }^{10}$ They would tend to persist until an economic crisis or future environmental change would cause a reassessment. ${ }^{11}$

While changes in conceptions of good corporate governance have occurred over the years, there is some consistency in firm behavior. As the power model of corporate governance would claim, firms have acted to decrease the uncertainty confronting them by not only reacting to their environment but also by seeking to change it through their business strategies and

Largest Firms, 1919-1979, in THE NEW INSTITUTIONALISM IN ORGANIZATIONAL ANALYSIS 311, 334-35 (Walter W. Powell \& Paul J. DiMaggio eds., 1991) [hereinafter Fligstein, The Structural Transformation of American Industry] (noting that some form of shock is necessary but is not a sufficient condition for change).

5. See, e.g., Fligstein, The Transformation of Corporate Control, supra note 3, at 20; Fligstein, The Structural Transformation of American Industry, supra note 4, at 322.

6. See Fligstein, The Structural Transformation of American Industry, supra note 4, at 322-23; Zorn, supra note 4, at 348 .

7. Fligstein, The TRANSFORMATION OF CORPORATE CONTROL, supra note 3, at 12 .

8. See Fligstein, The Structural Transformation of American Industry, supra note 4, at 332; Zorn, supra note 4, at 348 .

9. See Fligstein, The Transformation of Corporate Control, supra note 3, at 11, 18; Neil Fligstein, The Intraorganizational Power Struggle: Rise of Finance Personnel to Top Leadership in Large Corporations, 1919-1979, 52 AM. Soc. REV. 44, 56 (1987) [hereinafter Fligstein, The Intraorganizational Power Struggle]; Fligstein, The Structural Transformation of American Industry, supra note 4, at 322-23.

10. Zorn, supra note 4, at 348-49 (calling this "stages-of-institutionalization thesis"); see Fligstein, The Structural Transformation of American Industry, supra note 4, at 311, 332-35 (discussing the role of inertia but also the possibility for change).

11. See Zorn, supra note 4 , at 348 . 
attempts to influence regulations. ${ }^{12}$ Over the years firms have sought to increase their market share, profits, and stock prices. ${ }^{13}$ More recently, with the increasing power of financial markets, they have sought to increase their autonomy and discretion by seeking to meet the quarterly earnings expectation of security analysts and the demands of short-term shareholders. ${ }^{14}$

Most legal scholars take the triumph of the current shareholder value maximization conception of good corporate governance as a given, so entrenched that it is unlikely to change. ${ }^{15}$ That is a mistake. As this Article shows, conceptions of good corporate governance change over time, and the beliefs and circumstances that produced the current round of corporate governance are waning, setting the stage for far-reaching changes. This Article is a comprehensive examination of the forces that produced the current era of corporate governance. It explains why they are unlikely to determine the next round of corporate governance, and proposes a new model better suited to the era on the horizon.

This Article utilizes a broad definition of conceptions of "corporate governance." It refers to managers' perceptions of proper corporate purposes, strategies, and structures. It embraces managers' perceptions of their environment and their ideals regarding such matters as their firm's interactions with competitors, stakeholders, and the government. Thus, this approach broadens the use of the term "corporate governance" that arose during the 1980 s centering on the relationship between managers and shareholders and focusing on managerial misconduct. ${ }^{16}$ This narrow agency-theory perception is reflected in the shareholder value maximization conception of corporate governance. ${ }^{17}$ The broader definition of corporate governance permits consideration of the period prior to dispersed shareholding concerns,

12. Lynne L. Dallas, Two Models of Corporate Governance: Beyond Berle and Means, 22 U. Mich. J.L. REFoRM 19, 39-40 (1988) [hereinafter Dallas, Two Models of Corporate Governance]; see Fligstein \& Markowitz, supra note 1, at 192 (stating that firms have sought to achieve "stable patterns of interactions with their largest competitors" that decreases the uncertainty they confront).

13. Dallas, Two Models of Corporate Governance, supra note 12, at 40 n.63 (discussing Henry Mintzberg's hierarchy of firm goals under managerialism: survival, degree of efficiency to ensure survival, control of environment to ensure adequate degree of independence, and growth); see infra Parts II-IV; see also Fligstein, The TrAnsformation OF CORPORATE CONTROL, supra note 3 , at 5 (noting that the predominant firm objective is survival).

14. See infra Section IV.A.2.

15. See, e.g., Stephen M. Bainbridge, Unocal at 20: Director Primacy in Corporate Takeovers, 31 DEL. J. CORP. L. 769, 777-78 (2006).

16. Brian R. Cheffins, Corporate Governance Since the Managerial Capitalism Era, 89 Bus. Hist. Rev. 717, 731 (2015) [hereinafter Cheffins, Corporate Governance] (observing that "during the 1980s corporate governance became increasingly associated with shareholder returns," with economists "recoil[ing] from the 1970s version of corporate governance [that] implied the corporation was a political structure to be governed").

17. See infra Sections III.B-C and Part IV. 
at the turn of the nineteenth century, when the central issues were trusts and the concentration of power in a few firms. ${ }^{18}$ The focus of discussion about corporate governance, as broadly defined, was then on injury to small competitors and the public rather than shareholders. ${ }^{19}$ Moreover, during periods of our history, the power of autonomous, non-owner managers was viewed by many, not mainly as a source of managerial misconduct, but as a means to encourage managerial professionalism and the emergence of industrial statesmen who would serve the interests of all stakeholders and society. ${ }^{20}$ Public shareholders were considered passive investors with major legislative protections of them mainly focused on their role as investors. ${ }^{21}$ It was only when agency theory became pervasive and institutional investors came to control large shareholdings in public firms that corporate governance, as narrowly defined, came to occupy fully the corporate governance space with corporate purpose, strategies, and structures centered on shareholder value maximization. ${ }^{22}$

In earlier periods in U.S. business history, the central purpose of corporate governance was not to maximize stock prices, but to achieve growth, with survival and profit mainly as constraints. ${ }^{23}$ Managers adopted a variety of strategies that dominated the economic landscape in different time periods to achieve these objectives. They included cartels, trusts, holding companies, vertical integration, and the unitary/functional, multidivisional, and conglomerate organizational forms. ${ }^{24}$ These strategies had positive as well as negative consequences that often caused their use to be moderated or curtailed. ${ }^{25}$ Sometimes criticism of these strategies came from the public and demanded governmental attention. These strategies were not inevitable but resulted from managerial conceptions of what was "good" corporate governance during the different time periods.

This is also true for the modern era in which many managers have adopted strategies to maximize shareholder value. Disaggregation and

18. See infra Section II.A.

19. See infra Section II.A.

20. See infra text accompanying notes 115-17.

21. See infra text accompanying note 79.

22. See infra Sections III.B-C; see also infra Part IV (discussing the consequences of shareholder value maximization).

23. See supra note 13. See also John Whiteclay Chambers II, The Tyranny of Change: America In THE Progressive ERA 1890-1920, at 55 (2d ed. 1992).

24. See infra Part II and Section III.A.

25. See infra Part II and Sections III.A-B. 
cost-cutting strategies have dominated this time period. ${ }^{26}$ Like prior managerial strategies, they are not inevitable and have some negative consequences. These consequences include problematic managerial incentives, short-termism, the unsettling empowerment of short-term investors and financial firms, and adverse distributional consequences, discussed in this Article. ${ }^{27}$ As with prior eras, negative consequences are leading to changes. For instance, I see on the horizon the emergence of the sustainability conception of corporate governance. ${ }^{28}$ Rather than focusing solely on shareholders, managers with this emerging dominant conception would take a broader view of their role to consider as central to their business strategies the long-term societal value they create and the interests of all stakeholders. ${ }^{29}$

In Part II, I briefly examine the earlier conceptions of corporate governance to provide a background for understanding how corporate governance changes over time. Looking at changes in the past provides hope for change in the future. I then examine more recent finance conceptions of corporate governance in Part III - the portfolio and the shareholder value maximization conceptions. In this Part, I include my analysis of the shaky foundation of the shareholder value maximization conception that emerged in the late 1970 s and 80 s. I argue that it was improperly grounded primarily on claims of managerial self-interest in forming conglomerates in the 1960s and 70s. Finally, in Part IV I identify the adverse economic and social consequences of the shareholder value maximization conception of corporate governance. Having set the stage for change in the current era due to these adverse consequences, I present a new model of corporate governancethe sustainability conception - that I believe is emerging and will be supported by reforms that I propose. Part V concludes. Note that this Article focuses mainly on non-financial firms (hereinafter "firms") and only touches briefly on labor history.

I observe that the evolving conceptions of corporate governance show an ongoing dynamic at work where the changes we make in the world change the world in which we live. That world in turn changes our vision and the changes we then make, and so on. It is this process of learning from change that defines evolving conceptions of corporate governance as we look back and forward.

26. See infra Sections III.C, IV.A.8, 10.

27. See infra Section IV.A.

28. See infra Section IV.B.

29. See infra Section IV.B. 


\section{EARLY CONCEPTIONS OF “GOOD” CORPORATE GOVERNANCE}

This Part explores early conceptions of "good" corporate governance over the years through the 1960 s.

\section{A. Cooperation Among and Acquisition of Competitors}

In the early nineteenth century, firms required a state charter to form and were formed mainly for public purposes. ${ }^{30}$ Firms were considered artificial entities with powers conferred on them by the state through chartering. ${ }^{31}$ As opposition grew to special privileges granted by legislatures through chartering, states in the mid-1800s began adopting general incorporation statutes that permitted persons to form firms by merely filing articles of incorporation with the state. ${ }^{32}$ However, responding to a general fear of the growing economic power of some firms, states initially imposed limits on firms, such as on their size and duration, and prohibited them from owning stock in other firms. ${ }^{33}$ These limitations diminished as the century progressed. ${ }^{34}$ This led to new ideas about the theory of the firm, away from the artificial entity view of the firm to private views of the firm as a contractpartnership among owners or as natural/real entities. ${ }^{35}$ It is believed that

30. JoNATHAN LEVy, Freaks OF Fortune: The EMERGING WORLD OF CAPITALISM AND RISK IN AMERICA 275 (2012); David Millon, Theories of the Corporation, 1990 DUKE L.J. 201, 207 [hereinafter Millon, Theories of the Corporation]; cf. Margaret M. Blair \& Elizabeth Pollman, The Derivative Nature of Corporate Constitutional Rights, 56 WM. \& MARY L. REV. 1673, 1682-83, 1695 (2015).

31. Morton J. Horwitz, Santa Clara Revisited: The Development of Corporate Theory, 88 W. VA. L. REV. 173, 181 (1986) (referring to this view as the grant or concession theory of the firm); Millon, Theories of the Corporation, supra note 30, at 206.

32. See LEVY, supra note 30, at 275 n.23; Horwitz, supra note 31, at 181; Millon, Theories of the Corporation, supra note 30, at 207-08.

33. Millon, Theories of the Corporation, supra note 30, at 208-10.

34. Id. at $211-12$

35. Horwitz, supra note 31, at 181-82; Millon, Theories of the Corporation, supra note 30, at 202-03, 213-16; see 1 Victor Morawetz, A TrEATISE ON THE LAW OF PRIVATE Corporations $\S 515$, at 482 (Boston, Little, Brown, \& Co. 2d ed. 1886) (reflecting the contractual-partnership view of the firm); Gregory A. Mark, The Personification of the Business Corporation in American Law, 54 U. CHI. L. REV. 1441, 1458-64, 1471-73 (1987) (discussing the courts' gradual adoption of a partnership vision of the corporation-proposed by corporate attorneys - that viewed corporate property as the individual shareholders' property and the natural or real person/entity view); cf. Eric W. Orts, Theorizing the Firm: Organizational Ontology in the Supreme Court, 65 DePAul L. REV. 559, 564 (2016) (rejecting the necessity of choosing under institutional theory between an artificial entity and aggregate view of the firm). 
the natural/real entity view that came to the fore legitimized the emergence of big businesses in the late nineteenth century and early twentieth century. ${ }^{36}$

The dominant conception of good corporate governance for firms in the late nineteenth century was to seek survival and growth, mainly through cooperating with or acquiring competitors. ${ }^{37}$ This period was characterized by the significant growth of firms and beginning in the 1890s, many large industrial firms, encouraged by investment bankers, began listing their securities on the Stock Exchange. ${ }^{38}$

During 1870-1895 intense price competition and overproduction contributed to recurring financial panics and recessions. ${ }^{39}$ Many managersusually the founders - of firms requiring large capital investments believed that intensive competition and such major contractions threatened the survival of their industries. ${ }^{40}$ The initial strategies adopted by firms were cartel and pooling agreements and then trusts. ${ }^{41}$ Many industrial and financial leaders, some economists, and others at the time justified industrial concentration as inevitable, desirable, and "necessary to compete effectively against European cartels in the international market." 42 They contended that trusts were the outcome of a historical process of development from the individual to the partnership to the corporation to the trust. ${ }^{43}$ However, there was considerable public opposition to these new concentrations of economic

36. See LEVY, supra note 30 , at 275; Horwitz, supra note 31 , at 175-76, 185-90, 200-02 (explaining that the natural entity view supported firm growth with limited liability for shareholders, the abandonment of shareholder unanimity, and the demise of the ultra vires doctrine); Mark, supra note 35, at 1480-82; Millon, Theories of the Corporation, supra note 30 , at 216 ("The existence as well as the size of the business corporations were considered natural phenomena. As such, there no longer appeared to be any justification for legal regulation peculiar to corporate (as opposed to individual) activity, and the state's traditional regulatory responsibility was deemphasized.").

37. See Fligstein, The TRANSFORMATION OF CORPORATE CONTROL, supra note 3, at 12-13, 33-37.

38. See id. at 23-24, 38-39

39. Id. at 37-38; LEVY, supra note 30, at 276; List of Recessions in the United States, WIKIPEDIA, http://en.wikipedia.org/wiki/List_of_recessions_in_the_United_States [https://perma. $\mathrm{cc} / \mathrm{GWQ2}-\mathrm{X} 67 \mathrm{D}]$.

40. See Chambers II, supra note 23, at 56; Fligstein, The Transformation of CORPORATE CONTROL, supra note 3, at 37-38.

41. See Fligstein, The Transformation of Corporate Control, supra note 3, at 38-42, 57-58; Horwitz, supra note 31, at 190; Barak Orbach \& Grace Campbell Rebling, The Antitrust Curse of Bigness, 85 S. CAL. L. REV. 605, 606-08 (2012).

42. CHAMBERS II, supra note 23, at 60; see Horwitz, supra note 31, at 190-94.

43. Horwitz, supra note 31, at 194; see also LEVY, supra note 30, at 267, 290-91 (noting that a prominent financial leader of the time, George Walbridge Perkins, Sr., viewed the trusts as representing a beneficial public development from individualistic competition to cooperative risk management). 
power and cartels and trusts soon faced significant political and legal challenges that led firms to form holding companies. ${ }^{44}$

To assist firms, New Jersey in 1888 amended its corporation statute permitting firms to own shares in other firms. ${ }^{45}$ Other states soon followed suit and enabled firms to form holding companies. ${ }^{46}$ When some of the largest new industrial combinations continued to make profits by limiting the decline of prices in their industries during the depression that began in 1893 , emulators consolidated other industries when prosperity returned. ${ }^{47}$ The first great merger wave ensued between 1897 and 1903, fostered by weak enforcement of the Sherman Antitrust Act of 1890, with such consolidated firms as General Electric, International Harvester, DuPont, Eastman Kodak, U.S. Steel and Standard Oil coming to dominate their industries. ${ }^{48}$ The mergers consisted primarily of horizontal mergers of single-product firms with high levels of capital investments and low profits. ${ }^{49}$ The strategy of choice for the mergers was the holding company structure. ${ }^{50}$ The objective was to increase market share controlled by a single firm, concentrate production in plants operating at full capacity, and stabilize prices. ${ }^{51}$

Firms during this period sought to control and manage their environment in order to prosper and survive. ${ }^{52}$ They were successful in doing so, with

44. See ChAmBers II, supra note 23, at 194-95. Cartels also often failed for their inability to prevent defection. See FLIGSTEIN, THE TRANSFORMATION OF CORPORATE CONTROL, supra note 3, at 23, 57-58, 66; William E. Kovacic \& Carl Shapiro, Antitrust Policy: A Century of Economic and Legal Thinking, J. ECON. PERSP., Winter 2000, at 43, 44-45.

45. Millon, Theories of the Corporation, supra note 30, at 212 (citing Act of Apr. 4, 1888, ch. 269, 1888 N.J. Laws 385; Act of Apr. 7, 1888, ch. 295, 1888 N.J. Laws 445).

46. Id. Additionally, majority shareholder voting on mergers and other fundamental changes came to replace the unanimity requirement for such changes. Lynne L. Dallas, The Control and Conflict of Interest Voting Systems, 71 N.C. L. REV. 1, 10 (1992) [hereinafter Dallas, Voting Systems]; Millon, Theories of the Corporation, supra note 30, at 215.

47. Chambers II, supra note 23 , at 55 .

48. Id. The dates used for the depression and ensuing merger wave vary among sources. E.g., LEVY, supra note 30, at 274 (referring to the 1890 s depression and "the Great Merger Movement of 1895 to 1904 ").

49. Fligstein, The Transformation of Corporate Control, supra note 3, at 64 66,72 .

50. See id. at 57-60, 64, 66-67, 70-74 (discussing the problems with trusts and the advantages of mergers with the holding company becoming the surviving firm in mergers of previously competing firms); LEVY, supra note 30, at 276-77 (noting that New Jersey, by permitting holding companies, became the "legal home to the Great Merger Movement").

51. See Fligstein, The TRANSFORMATION OF CORPORATE CONTROL, supra note 3, at 57-60, 64 .

52. See id. at 57-60, 64, 76. 
large portions of industries being controlled by trusts and holding companies. For example, at its peak the Standard Oil Trust, formed in 1882, controlled $90 \%$ of the oil industry. ${ }^{53}$ These monopolization efforts were effective from the point of view of the firms and arguably society. ${ }^{54}$ But they drew public criticism for allegedly corrupting lawmakers, destroying opportunities for smaller competitive businesses, and wrecking a competitive market system with their administered prices. ${ }^{55}$ Cartels, trusts, and holding companies were challenged under state and federal antitrust laws. ${ }^{56}$ In the Reformist Progressive Era, oligopoly replaced monopoly, as a handful of large firms rather than a single giant corporation came to dominate several major industries. ${ }^{57}$ The entrepreneurial founders of firms, such as John D. Rockefeller of Standard Oil and other monopolists of his ilk, came to be criticized by many historians as "robber barons" or unscrupulous, freewheeling buccaneers, while some others continued to uphold them and their memory as innovative "captains of industry." 58

\section{B. Manufacturing and the Unitary, Functional Form of Organization}

By the end of the nineteenth century, firms were reaching out to public shareholders for capital by listing their shares on the Stock Exchange. Corporate power gradually shifted from the shareholders to managers. ${ }^{59}$ In addition, professional managers began to replace founding entrepreneurs. ${ }^{60}$ The contract-partnership theory of the firm became less reflective of reality than the natural/real entity theory given firms' functional economic autonomy

53. Id. at 48. Another example is International Paper Inc., a holding company that controlled $75 \%$ of the U.S. paper market. Id. at 63-64. It subsequently closed less efficient plants in favor of operating larger, newer plants. See id. at 76.

54. Although they were not able to attain above average pricing because of competition from existing competitors and new entrants, they were able to stabilize prices. Id. at 10608. Jonathan Levy quotes John D. Rockefeller, who stated, "[W]e were all in a sinking ship, if existing cutthroat competition continued .... The Standard Oil Company was an angel of mercy ...." LEVY, supra note 30, at 264.

55. See CHAMBERS II, supra note 23, at 58-60 (noting that they were also criticized for monopolizing credit and stimulating inflation); Orbach \& Rebling, supra note 41, at $606,608$.

56. See Fligstein, The Transformation OF CORPORATE CONTROL, supra note 3, at 66-67, 70-74, 96-98, 106-08; Kovacic \& Shapiro, supra note 44, at 45. Trusts were also challenged under state law.

57. For example, U.S. Steel's market dropped from $62 \%$ in 1901 to $40 \%$ in 1920 . Standard Oil's share of refined petroleum, among its successor regional Standard Oil companies, dropped from $90 \%$ in 1899 to $50 \%$ in 1920 . ChAMBERS II, supra note 23 , at 57.

58. Orbach \& Rebling, supra note 41, at 606.

59. Dallas, Voting Systems, supra note 46, at 9-10; see Millon, Theories of the Corporation, supra note 30, at 215-16.

60. See CHAMBERS II, supra note 23, at 56 (discussing the "rise of substantial corporate bureaucracies" to deal with the new "supercorporations"). 
that was in the hands of managers rather than incorporators or shareholders. ${ }^{61}$ Directors were no longer considered agents of the shareholders. ${ }^{62}$ Courts viewed directors' powers as neither conferred nor revocable by the shareholders. ${ }^{63}$ Firms were viewed as having their own personality. ${ }^{64}$ They were "autonomous, self-sufficient and renewing bod[ies]," private, and separated from the state and from their shareholders who were seen as mere investors. ${ }^{65}$

In the early twentieth century the dominant conception of corporate governance was to seek survival and growth by integrating and protecting the manufacturing operations of the firm. ${ }^{66}$ Professional managers with manufacturing backgrounds became the largest group of presidents. ${ }^{67}$ Many firms formed by mergers during the great consolidation, 1897 to 1903, were no longer in existence, indicating inefficiencies with their structure and competition from existing competitors and new entrants. ${ }^{68}$ Thus, to better manage their firms, managers moved from the holding company structure to the unitary, functional form of corporate governance that integrated the firm's activities into separate departments that specialized in specific functions, such as purchasing, manufacturing, and distribution. ${ }^{69}$

Managers also increasingly sought to protect their manufacturing operations through vertical integration. ${ }^{70}$ Vertical integration enabled firms to control the functions relevant to the production and distribution of their products and protected the large investments required in plants. ${ }^{71}$ It was also used as a defensive strategy due to the fear that competitors would vertically

61. See Mark, supra note 35, at 1465, 1472, 1479-80; Millon, Theories of the Corporation, supra note 30 , at 213-16.

62. Horwitz, supra note 31, at 183.

63. See Dallas, Voting Systems, supra note 46, at 9-10; Millon, Theories of the Corporation, supra note 30, at 215; see, e.g., People ex rel. Manice v. Powell, 94 N.E. 634, 637 (N.Y. 1911).

64. See Millon, Theories of the Corporation, supra note 30, at 215-26.

65. Thomas P. Byrne, False Profits: Reviving the Corporation's Public Purpose, 57 UCLA L. REV. DisCOURSE 25, 34 (2010).

66. FligSteIn, THE TRANSFORMATION OF CORPORATE CONTROL, supra note 3, at 13-14.

67. Fligstein, The Intraorganizational Power Struggle, supra note 9 , at $47 \&$ tbl. 2 (noting that in the 100 largest firms from 1919-1939, manufacturing presidents increased from $23 \%$ to $34 \%$, and entrepreneurs declined from $28 \%$ to $18 \%$ ). Functional backgrounds are determined on the basis of previous job titles, not by education. Id. at 51 . 24.

68. Fligstein, The Transformation of Corporate CONTROL, supra note 3 , at

69. Id. at $109-10$

70. Id. at 14,75 .

71. Id. 
integrate and interfere with the firm's ability to obtain raw materials and machinery - particularly in times of shortage - and transport its products. ${ }^{72}$ It was also used offensively to exert control over competitors. ${ }^{73}$ Henry Ford, for example, acquired railroads, coal mines, timberland, freighter ships, and glass work plants in an attempt to control all aspects of the Model T's production. ${ }^{74}$

The merger movement in the period 1926 to 1930 contributed to the strengthening and creation of oligopolies in many industries due to horizontal and vertical integration. ${ }^{75}$ Despite the passage of the Clayton Act of 1914, antitrust was quite lax for twenty years after its passage. ${ }^{76}$ Therefore, firms' merger strategies were rational responses by individual managers to the environment of the time. One study found that the level of industry concentration and integration was related to the likelihood of firm survival. ${ }^{77}$ Moreover, the growth in sales, assets, and profits for the 100 largest firms from 19191929 was higher for vertically integrated firms than for other firms. ${ }^{78}$

\section{Marketing and Sales and the Multidivisional Form of Organization}

The Great Depression created a national crisis that caused rethinking of the way firms were regulated. A major regulatory development was the passage of the federal securities laws, most notably the Securities Act of 1933 and the Securities Exchange Act of 1934, which were intended to protect shareholders as investors, mainly through disclosure regulations. ${ }^{79}$ The famous debate between Professors Adolf A. Berle and E. Merrick Dodd, Jr. that occurred during this period focused on the separation of ownership from control in large corporations, concern over the accountability of non-

72. Id.

73. Id.

74. Frank Goad, Ford Motor Company - 100 Years of Advanced Manufacturing in Kentucky, LANE REP. (July 17, 2013), http://www.lanereport.com/22644/2013/07/fordmotor-co-100-years-of-advanced-manufacturing-in-kentucky/ [https://perma.cc/WK49-JE33]. Henry Ford is also known for developing the automobile assembly line, which required the integration of thousands of parts. CHAMBERS II, supra note 23, at 62.

75. See Fligstein, The Transformation of CORPORATE CONTROL, supra note 3, at 115; see also CHAMBERS II, supra note 23, at 57 ("Oligopoly, in which a handful of large firms dominated the market, characterized American industry .....”).

76. Kovacic \& Shapiro, supra note 44, at 46.

77. Fligstein, The TRANSFORMATION OF CORPORATE CONTROL, supra note 3, at 108-09.

78. Id. at 111 .

79. Securities Act of 1933, 15 U.S.C. $§ 77(a)$; Securities Exchange Act of 1934, 15 U.S.C. § 78(a); see Elisabeth Keller \& Gregory A. Gehlmann, Introductory Comment: A Historical Introduction to the Securities Act of 1933 and the Securities Exchange Act of 1934, 49 Oнiо ST. L.J. 329, 329-30 (1988). 
owner managers, and the power present in a small number of large firms ${ }^{80}$ Berle and Dodd agreed that governmental regulation was justified in regulating firms to assure societal benefits. ${ }^{81}$ However, Professor Berle viewed the firm as an aggregation of persons and opined at that time that it should operate in the sole interests of the shareholders ${ }^{82}$ until a "clear and reasonably enforceable scheme of responsibilities to someone else" could be devised. ${ }^{83}$ Professor Dodd, essentially relying on the natural entity theory, believed at that time that directors owed fiduciary duties not to the shareholders but to the firm, giving corporate statesmen leeway to serve not only the shareholders but other stakeholders as well. ${ }^{84}$

The Great Depression also caused a reconsideration of antitrust policy. Initially, the severity of the Great Depression was blamed in part on excessive competition driving prices below costs. ${ }^{85}$ Consequently, cooperation among competitors was viewed favorably as curbing "the wasteful features of competition." ${ }^{86}$ For various reasons, antitrust enforcement from 1915 to 1936 was tolerant of collusion and information sharing among competitors, and

80. Adolf A. Berle \& Gardiner C. Means, The Modern Corporation and Private Property 300-01 (Harcourt, Brace \& World, Inc. rev. ed. 1968); Millon, Theories of the Corporation, supra note 30, at 217-18; cf. MARK J. ROE, STRONG MANAGERS, WEAK OWners: The Political RoOTs of AMERICAN CoRporate Finance passim (1994) (explaining that this separation of control from ownership was not inevitable but was the result of politics); C.A. Harwell Wells, The Cycles of Corporate Social Responsibility: An Historical Retrospective for the Twenty-First Century, 51 U. KAN. L. REV. 77, 93-96 (2002) [hereinafter Wells, The Cycles of Corporate Social Responsibility] (discussing Berle and Dodd's concern with corporate power in a small number of firms).

81. BERLE \& MEANS, supra note 80, at 312; Dallas, Two Models of Corporate Governance, supra note 12 , at 20 n.5.

82. Millon, Theories of the Corporation, supra note 30, at 222-23 (explaining that "Berle and Means effectively disregarded notions of the corporate entity" and that the "theory of the corporation implicit in their work is of an aggregation composed of shareholders and management").

83. Adolf Berle, For Whom Corporate Managers Are Trustees: A Note, 45 HARV. L. REV. 1365, 1367 (1932).

84. E. Merrick Dodd, Jr., For Whom Are Corporate Managers Trustees?, 45 HARV. L. REV. 1145, 1161 (1932); Millon, Theories of the Corporation, supra note 30, at 217 18; see Rick Wartzman, Whatever Happened to Corporate Stewardship?, HARV. Bus. REV. (Aug. 29, 2014), https://hbr.org/2014/08/whatever-happened-to-corporate-stewardship [https://perma.cc/WS65-UVRK]. Berle and Means later modified their positions to come closer to the other's position. See Wells, The Cycles of Corporate Social Responsibility, supra note 80 , at 96-98, 101-03.

85. Kovacic \& Shapiro, supra note 44, at 46-47.

86. Id. at 46. This was considered an "associational view" of the proper relationship between business and government. Id. 
dominant firm behavior was, in general, treated leniently. ${ }^{87}$ However, President Franklin D. Roosevelt abandoned this approach in the mid-1930s ${ }^{88}$ A number of lawsuits were brought against dominant firms for collusive and anticompetitive behavior, an approach supported by University of Chicago economists at the time. ${ }^{89}$ A period of active antitrust enforcement ensued from the mid-1930s until the early 1970s, except during World War II. In 1950 a majority of the hundred largest U.S. firms were defendants in antitrust lawsuits. ${ }^{90}$ Courts found per se illegal both price fixing agreements among competitors and tying arrangements used by firms to further their sales of related products..$^{91}$ In 1950, Congress passed the Celler-Kefauver Act that controlled the acquisition of market share through horizontal and vertical transactions. ${ }^{92}$ Small foreclosures of competition in submarkets through mergers were found illegal under the Act. ${ }^{33}$

Although firms in the 1920s had begun to focus on sales and marketing, this firm strategy accelerated after the Great Depression when firms observed that firms that had expanded into related products were more successful in surviving the Depression. ${ }^{94}$ Countercyclical product offerings provided some revenue stability and opportunities for firm growth, and related product offerings allowed firms to achieve economies of scale in production and product distribution. ${ }^{95}$ Moreover, active antitrust enforcement after the Depression that challenged horizontal and vertical integration propelled firms to seek to grow by developing related product lines. ${ }^{96}$

Unlike previous periods, firms avoided direct competition with competitors by engaging in product differentiation that appealed to different consumer market segments — in terms of quality, style, and price — and by expanding

87. Id. at $47-48$.

88. Id. at 49.

89. See id. at $49-51$.

90. Fligstein, The Structural Transformation of American Industry, supra note 4, at 321.

91. E.g., N. Pac. Ry. Co. v. United States, 356 U.S. 1, 1-2 (1958) (finding agreements that condition or tie the sale of one product with the purchase of another illegal per se); United States v. Socony-Vacuum Oil Co., 310 U.S. 150, 150 (1940) (condemning as illegal per se arrangements among competitors to fix prices); see Kovacic \& Shapiro, supra note 44 , at 50.

92. The Clayton Antitrust Act of 1914, 15 U.S.C. $\S 18$ (1996).

93. E.g., United States v. Pabst Brewing Co., 384 U.S. 546, 547-48 (1966); Brown Shoe Co. v. United States, 370 U.S. 294, 294 (1962); see Kovacic \& Shapiro, supra note 44, at 51.

94. Fligstein, The Transformation OF Corporate Control, supra note 3, at 119 , 138-39. The Progressive Era saw the development of the mass marketing of products through advertisements, dealerships, service stations, and chain stores. See CHAMBERS II, supra note 23 , at 63 .

95. See Fligstein, The Transformation OF CORPORATE CONTROL, supra note 3 , at $124-25,228-31$.

96. See Kovacic \& Shapiro, supra note 44, at 49-52. 
into new geographical markets, including global markets. ${ }^{97}$ Firms focused on expansion rather than predatory competition. ${ }^{98}$

Product diversification, although spreading unevenly among industries, continued into the post-WWII years. ${ }^{99}$ To facilitate the expansion into related products, many firms replaced the unitary, functional form of corporate governance with the multidivisional form. ${ }^{100}$ Firms allocated to division managers the responsibility for most of the functions associated with producing and distributing specified products. ${ }^{101}$ Management was largely decentralized with the central office retaining only limited functions, such as in finance and new product research. ${ }^{102}$ As for vertical integration, the Depression demonstrated the vulnerability of vertically integrated firms during business downturns because of the substantial investments necessary to integrate. ${ }^{103}$ However, vertical integration increased in the years following 1919 but began to decline in $1959 .{ }^{104}$

Advertising by firms increased during this period, ${ }^{105}$ as did the percentage of presidents with sales and marketing backgrounds in large firms. ${ }^{106}$ However, during the period 1939 to 1959, manufacturing presidents were

97. Fligstein, The Transformation OF CORPORATE CONTROL, supra note 3 , at 123 , 145 tbl.4.1, 232 (showing that the percentage of the 100 largest firms selling in global markets increased from $20 \%$ in $1919-1929$, to $62 \%$ in $1948-1959$, to $88 \%$ by $1969-1979$ ).

98. Id. at 14 .

99. Id. at 145 tbl.4.1. The percentage of the 100 largest firms with related product diversification increased from $13 \%$ in $1919-1929$, to $34 \%$ in $1948-1959$, and to $54 \%$ by $1959-1969$. Id.

100. See id. at 233-38. The multidivisional form was used as early as the 1920s to accommodate diverse product lines. However, its use by the 100 largest firms increased from $8 \%$ in 1939 to $73 \%$ in 1969 , with the greatest percentage change occurring from 1948-1959. Fligstein, The Intraorganizational Power Struggle, supra note 9, at 53.

101. Fligstein, The Transformation OF CORPORATE ConTrol, supra note 3, at 17.

102. Id.; Fligstein, The Intraorganizational Power Struggle, supra note 9, at 48.

103. See Fligstein, The Transformation of Corporate CONTROL, supra note 3 , at 117 .

104. Id. at $145-46,145$ tbl.4.1.

105. Advertising increased from $\$ 500$ million to $\$ 1.5$ billion from $1921-1927$, and from $\$ 3.2$ billion to $\$ 10$ billion from 1946-1956. Id. at 124, 232. An estimated $\$ 50$ million was spent on market research, up from $\$ 10$ million before WWII. Id. at 231. Firms often set up research and development departments to explore new products and marketing research departments. Id. at 231-32. Market research directors at many firms attended high-level policy meetings. Id.

106. Fligstein, The Intraorganizational Power Struggle, supra note 9, at $47 \&$ tbl.2 (finding that in the 100 largest firms from $1939-1959$, sales presidents increased from $14 \%$ to $22 \%$, finance presidents increased from $6 \%$ to $16 \%$, and manufacturing presidents declined from $34 \%$ to $26 \%$ ). 
more likely to head single product firms with the unitary, functional form, whereas marketing and sales presidents were more likely to head multidivisional firms with related product strategies. ${ }^{107}$ Moreover, firms were more likely to switch to related product diversification if they had marketing and sales presidents and if they saw new firms successfully using this strategy. ${ }^{108}$ Firms navigated their environment to increase their opportunities to grow by increasing their sales in related products. ${ }^{109}$

This focus on growth was consistent with the objectives of firm managers during this period who identified with their firms and relied on them for career mobility and security. ${ }^{110}$ Firm growth provided opportunities for bureaucratic advancement and many employees spent their work lives at the same firm as they worked their way up the firm job ladder. ${ }^{111}$ CEOs viewed themselves as stewards of their firms, concerned with its survival and long-term wellbeing. ${ }^{12}$ In the three decades following World War II into the 1970s, this view, referred to by some as "managerialism," prevailed. ${ }^{113}$ Firm managers considered themselves "organization" men loyal to their firms and as part of a team devoted to the work performed by their firms. ${ }^{114}$ As

107. Id. at 55 .

108. See Fligstein, The Transformation of Corporate Control, supra note 3 , at $158-60$.

109. See Fligstein, The Intraorganizational Power Struggle, supra note 9, at 49.

110. John KenNeth Galbraith, The New Industrial State 156-66 (2d ed., rev. 1971) (explaining that managers identified with the long-term wellbeing of their firm because of their long tenure with it as they climbed up the corporate ladder); June Carbone \& Nancy Levit, The Death of the Firm, 101 MinN. L. REV. 963, 980 (2017) (noting that managers under managerialism viewed their "success and well-being far more with the health and prestige of their companies than with their individual bank accounts," and how "employment became a foundation for individual security" as firms had greater "firm investment in workers and a correspondingly greater commitment to worker tenure").

111. William K. Black \& June Carbone, Economic Ideology and the Rise of the Firm as a Criminal Enterprise, 49 AKRON L. REV. 371, 383-84, 386-87 (2016); see also Rosemary L. Batt \& Eileen Appelbaum, The Impact of Financialization on Management and Employment Outcomes 7-8 (W.E. Upjohn Inst. for Emp't Research, Working Paper No. 13-191, 2013) (explaining how a long-term perspective served the interests of managers as well as others).

112. E.g., Black \& Carbone, supra note 111, at 385-88 (noting that CEOs viewed themselves as stewards of their firms concerned with its long-term wellbeing); Carbone \& Levit, supra note 110, at 990 ("[C]orporate managers embraced the corporate brand and saw their role as one of stewardship of the institution.").

113. E.g., Rakesh Khurana, The Curse of the Superstar CEO, HaRv. Bus. Rev., Sept. 2002, at 60, 62 .

114. Black \& Carbone, supra note 111, at 383-84 (citing Lynn A. Stout, On the Rise of Shareholder Primacy, Signs of Its Fall, and the Return of Managerialism (in the Closet), 36 Seattle U. L. REV. 1169, 1171 (2013)); Carbone \& Levit, supra note 110, at 978-79 (discussing the importance of group decision making in the managerial firm, which led to a high expectation of personal honesty and benefits resulting from being part of a group rather than competing for individual bonuses and perks); Cheffins, Corporate Governance, supra note 16 , at 723 . 
industrial statesmen, they accommodated a wide range of constituencies, including shareholders, employees, consumers, and suppliers. ${ }^{115}$ In what was referred to as "capitalism with a conscience" or "enlightened conservatism," managers during this period came to judge their decisions not only based on profitability but also on their impact on society. ${ }^{116}$ Exemplifying this approach was the statement of the president of the U.S. Chamber of Commerce in 1956: "Business today views its own work through the eyes of the community and looks to the total welfare in terms of the long pull."117 Many executives participated in community projects, and their firms encouraged them to become civic leaders. ${ }^{118}$

Throughout U.S. history there were public debates about the purposes and methods of corporations, particularly when power became concentrated in a few firms in various industries. ${ }^{119}$ These debates occurred regardless of the particulars of share ownership. ${ }^{120}$ However, when passive, public shareholders acquired shares in major firms, theoretical debates arose concerning the consequences of the separation of property from control of the corporation as exhibited by the Berle-Dodd debates discussed previously. ${ }^{121}$ Did this provide a theoretical basis for requiring firms to operate in the public interest or was governmental intervention necessary to assure managerial accountability to shareholders? ${ }^{122}$ Initially, a system of managerialism arose in which control of the firm was for most practical purposes in the hands of professional managers. ${ }^{123}$ This system had some advantages, particularly in the 1950s and 60s when many managers viewed themselves as stewards of their firms and as accommodating the interests

115. Wartzman, supra note 84; see Black \& Carbone, supra note 111, at 394-95; Cheffins, Corporate Governance, supra note 16, at 730; Sanford M. Jacoby, Employee Representation and Corporate Governance: A Missing Link, 3 U. PA. J. LAB. \& EMP. L. $449,454-55$ (2001) (referring to this ethos as "welfare capitalism"). There is evidence that these views were also held in the beginning of the 1980s. Ralph Gomory \& Richard Sylla, The American Corporation, DAEDALUS, Spring 2013, at 102, 107 (discussing the views of the Business Roundtable in 1981).

116. E.g., The New Conservatism, Time, Nov. 26, 1956, at 98, 98.

117. Id.

118. Time and Talent Means More Than Money, Time, Sept. 24, 1956, at 86, 86 (explaining how some top executives spend up to one-third of their time on community projects).

119. Wells, The Cycles of Corporate Social Responsibility, supra note 80, at 77-79, 99-101.

120. See id. at $98-100$.

121. See id. at $87-96$.

122. See id. at $98-99$.

123. Id. at 84 . 
of various stakeholders. It should be noted that various sources of countervailing power existed to managerial power during this period that facilitated a stakeholder approach, such as from governmental regulations and labor. ${ }^{124}$ Managerialism persisted until later challenged by the shareholder value maximization conception of corporate governance that emerged in the late 1970s and became generally accepted in the 1980s and 90s and thereafter.

\section{MODERn CONCEPTIONS OF “GOOD” CORPORATE GOVERNANCE}

This Part is devoted to the modern finance conceptions of corporate governance. In Part III.A I discuss the portfolio conception of corporate governance and the conglomerate form of organization. In Part III.B I explore the origins of the shareholder value maximization conception and provide a retrospective analysis of conglomerates. I discuss in Part III.C the emergence of the shareholder value maximization conception and disaggregation strategies.

\section{A. The Portfolio Conception and Conglomerates}

The portfolio conception of "good" corporate governance prevailed in the 1960s and 70s. It viewed the firm as a "bundle of assets," each evaluated on the basis of its risk profile and rate of return, and embraced conglomeration. ${ }^{125}$ This finance conception was supported by modern accounting systems, portfolio theory, and simplified the evaluation of firms' operations that were embodied by that time in the multidivisional form of organization. ${ }^{126}$ The portfolio conception of the firm and the multidivisional form supported the belief that firms should expand beyond producing related products into

124. See ChAMBERS II, supra note 23, at 67-68, 70-74; Wells, The Cycles of Corporate Social Responsibility, supra note 80, at 99.

125. Fligstein \& Markowitz, supra note 1, at 192; Gerald F. Davis et al., The Decline and Fall of the Conglomerate Firm in the 1980s: The Deinstitutionalization of an Organizational Form, 59 AM. Soc. REv. 547, 547 (1994) [hereinafter Davis et al., The Decline and Fall of the Conglomerate Firm] (referring to the "firm-as-portfolio" model). The view of the firm as a bundle of assets is also associated with managers' finance view of their firms in later eras although it was not, as it was in the 1960s and 70s, associated with conglomeration. See Fligstein \& Markowitz, supra note 1, at 187; William Ocasio \& Hyosun Kim, The Circulation of Corporate Control: Selection of Functional Backgrounds of New CEOs in Large Manufacturing Firms, 1981-1992, 44 ADMIN. SCI. Q. 532, 532 (1999); Özgür Orhangazi, Financialisation and Capital Accumulation in the Non-Financial Corporate Sector: A Theoretical and Empirical Investigation on the US Economy: 19732003, 32 CAMBRIDGE J. ECON. 863, 868 (2008).

126. See Fligstein, The Transformation of Corporate Control, supra note 3, at 14, 75; Davis et al., The Decline and Fall of the Conglomerate Firm, supra note 125, at 553. 
the production of unrelated products. ${ }^{127}$ In this way firms could diversify their portfolios of investments and attain the advantages of portfolio diversification. The main tools of the finance conception of corporate governance were mergers, divestitures, stock repurchases and the rebalancing of debt and equity. ${ }^{128}$

The view of the firm as a portfolio of assets was exemplified by the merger wave of the 1960s and early 1970. During this period many large firms became conglomerates as a way to expand and diversify their portfolios. ${ }^{129}$ The growth of firms into unrelated products was also particularly attractive because of the risks during this period of antitrust challenges for firms that grew horizontally or vertically. ${ }^{130}$

The portfolio conception was also associated with the increase in finance presidents in the $1960 \mathrm{~s}$ and $70 \mathrm{~s} .{ }^{131}$ In the 100 largest U.S. firms during the period 1959 to 1979 the percentage of finance presidents increased from $16.1 \%$ to $27.5 \%{ }^{132}$ Finance presidents were inclined as a result of their training to view the operations of their firms mainly in financial terms. Chief financial officers (CFO) also began to enter the executive suite during this period. The rise of the CFO, often second to the CEO, indicated "a fundamental shift in power, visibility, and strategic importance of the finance function."133 A number of factors made the expertise of a CFO especially important. For instance, CFOs were in demand to navigate the FASB accounting rules adopted in 1979 that required the disclosure of asset replacement cost information that would have an effect on firm

127. See Davis et al., The Decline and Fall of the Conglomerate Firm, supra note 125, at 547.

128. Batt \& Appelbaum, supra note 111, at 3; Fligstein \& Markowitz, supra note 1, at $192-93$.

129. Fligstein, The Structural Transformation of American Industry, supra note 4, at $311,321$.

130. Timothy M. Hurley, The Urge to Merge: Contemporary Theories on the Rise of Conglomerate Mergers in the 1960s, 1 J. BUS. \& TECH. L. 185, 195-97 (2006); Kovacic \& Shapiro, supra note 44, at 51.

131. See Batt \& Applebaum, supra note 111, at 6 (viewing the decline of managerial capitalism in favor of finance capitalism as beginning in the 1950s).

132. Fligstein, The Intraorganizational Power Struggle, supra note 9, at 47 tbl.2. In the 100 largest U.S. firms during the period 1959-1979, generalist presidents increased from $10.4 \%$ to $15.8 \%$ and lawyers declined from $9.6 \%$ to $6.7 \%$. Id.

133. Zorn, supra note 4, at 347, 353. Regarding the enhanced importance of the CFO's role, see id. at $347,352,361$. 
earnings. ${ }^{134}$ The first major company hired a CFO in $1966 .{ }^{135}$ This practice gradually spread among major firms. ${ }^{136}$

\section{B. The Origins of the Shareholder Value Maximization Conception and a Retrospective Analysis of Conglomerates}

Economists in the late 1970s provided the theoretical underpinning for a shareholder value maximization conception. Unlike managerialism, this conception meant the firm's purpose was to maximize shareholder value. It is based on the "nexus of contract" theory of the firm. ${ }^{137}$ This theory is a disaggregation view of the firm, that is, the firm is a nexus or a mere connection among private, contracting parties rather than an entity. It serves as a marketplace in which goods and services are exchanged. The firm is analogized to a spot market, like a wheat or stock market. ${ }^{138}$ Thus, this theory rejects the view that the firm is a political or social actor. As Michael Jensen and William Meckling stated in their influential 1976 article: "We seldom fall into the trap of characterizing the wheat or stock market as an individual, but we often make this error by thinking about organizations as if they were persons with motivations and intentions."139 Thus, with this theory, it makes no sense to view the firm as a social institution or as a person with social responsibility. ${ }^{140}$ It is merely a financial construct with the goal of efficiency being achieved by the maximization of shareholder value. ${ }^{141}$ This perspective came to be called "agency theory" with managers viewed as the agents of shareholders. ${ }^{142}$

134. Id. at 351. Due to high inflation, many major firms had asset values lower than their stock market values. CFOs came to the fore with their abilities to find ways to leverage capital, evaluate acquisitions and divestitures, and fend off hostile takeovers. Id. at 361 \& n.9.

135. Id. at 354,356 .

136. See id. at 346 (finding that by the year $2000,80 \%$ of the 400 largest firms had CFOs)

137. See Armen A. Alchian \& Harold Demsetz, Production, Information Costs, and Economic Organization, 62 AM. EcON. ReV. 777, 788 (1972); Michael C. Jensen \& William H. Meckling, Theory of the Firm: Managerial Behavior, Agency Costs and Ownership Structure, 3 J. FIN. ECON. 305, 310 (1976).

138. Jensen \& Meckling, supra note 137, at 311.

139. Id.

140. Id.

141. See Frank H. Easterbrook \& Daniel R. Fischel, The Proper Role of a Target's Management in Responding to a Tender Offer, 94 HARV. L. REV. 1161, 1191 (1981) ("So long as it continues to be lawful to form corporations for profit, shareholders are entitled to hire managers dedicated to the shareholders' interest alone. The duty of management is to operate efficiently and thus maximize the return to shareholders.").

142. Michael C. Jensen, Agency Costs of Free Cash Flow, Corporate Finance, and Takeovers, 76 Am. ECON. REv. 323, 323 (1986); William Lazonick \& Mary O'Sullivan, Maximizing Shareholder Value: A New Ideology for Corporate Governance, 29 ECON. \& 
As was the case throughout U.S. firm history, there were public pressures against a private view of the firm. For example, in the 1970s social activism arose when shareholder activists submitted proposals on social issues at annual shareholder meetings. ${ }^{43}$ This was exemplified by a shareholder proposal to stop the Dow Chemical Company from producing napalm for use in the Vietnam War, a move that garnered a lot of publicity. ${ }^{144}$ There were also calls for public-interest board directors, notably by Ralph Nader who orchestrated a campaign to add public interest directors to GM's board. ${ }^{145}$ However, armed with the new theoretical approach, shareholder activism in future years focused more on shareholder economic interests ${ }^{146}$ and led to changes that enhanced shareholder power. ${ }^{147}$

The new agency theory focusing on shareholders also became popular because of the academic prestige of its proponents and their efforts to widely disseminate their views to the business community and business school students. ${ }^{148}$ It also provided an easily understood explanation for problems facing businesses in the 1970s as they confronted the decline in their competitiveness with foreign firms and decreases in their stock prices. A major cause of these problems, according to agency theory, was the conflict of interest between managers and shareholders, that is, managers did not

Soc'Y 13, 15-16 (2000); Milton Friedman, The Social Responsibility of Business Is To Increase Its Profits, N.Y. Times, Sept. 13, 1970, at 33.

143. Lyman Johnson, Law and the History of Corporate Responsibility: Corporate Governance, 10 U. ST. THOMAS L.J. 974, 982 (2013). Public concerns over mismanagement by managers have pervaded U.S. corporate history. In the 1970 s, the failure of Penn Central and foreign bribery scandals received considerable public attention for destroying shareholder value. Wells, The Cycles of Corporate Social Responsibility, supra note 80, at 120 .

144. Johnson, supra note 143 , at $982-83$.

145. Id. at 979,983 .

146. Cheffins, Corporate Governance, supra note 16, at 731-32. "This trend did not yield radical changes" initially, but did over time. Id. at 732 .

147. These changes include the decline in staggered boards, the increase in majority voting for directors, changes that decrease the cost of proxy solicitations, the reduction in the scope of broker discretionary authority, developments in proxy access, and the failure to broaden in the context of hedge fund activism the definition of "group" for purposes of beneficial-ownership disclosures. John C. Coffee, Jr. \& Darius Palia, The Wolf at the Door: The Impact of Hedge Fund Activism on Corporate Governance, 41 J. CoRP. L. 545, 562 70 (2016); Marcel Kahan \& Edward Rock, Embattled CEOs, 88 TEX. L. REV. 987, $1007-$ $22(2010)$.

148. Rakesh Khurana, From Higher Aims to Hired Hands: The Social TRANSFORMATION OF AMERICAN BUSINESS SCHOOLS AND THE UNFULFILlED PROMISE OF MANAGEMENT AS A Profession 318-19, 321-23 (2007). 
maximize shareholder value. ${ }^{149}$ In the 1960 s and 70 s, agency theorists claimed that managers used cash flow to fund negative-net-present-value investments to diversify and grow their firms and failed to exit excess capacity industries. ${ }^{150}$ They purportedly acted in their self-interest rather than the interests of the shareholders by creating conglomerates. They were viewed as having been motivated by a desire to extend their control and increase their compensation that was based on firm size. ${ }^{151}$

This theory provided a simple answer to the crises of the time - managerial self-interest - and, perhaps not coincidentally, an answer that would serve the interests of financial firms who had become substantial shareholders in U.S. firms. ${ }^{152}$ The solution, according to agency theory, was for firms to maximize shareholder value and adopt means to assure managerial accountability in the future. ${ }^{153}$ Agency theorists viewed hostile takeovers and large debt levels as positive ways to discipline managers. ${ }^{154}$ They also encouraged boards of directors to align managerial compensation with the interests of shareholders and to make payouts to shareholders through dividends and stock buybacks, thus requiring managers to justify their investments by returning to the stock market for capital. ${ }^{155}$

The shareholder value maximization conception supported the merger wave of the $1980 \mathrm{~s}$, the largest merger wave to that point in U.S. history. 156 Over $29 \%$ of 1980 Fortune 500 companies received takeover offers during this period, most of which were hostile. ${ }^{157}$ This wave consisted of transactions that busted up many conglomerates. ${ }^{158}$ It was notable for the use by firms

149. Michael C. Jensen, Takeovers: Their Causes and Consequences, J. ECON. PERSP., Winter 1988, at 21, 28 [hereinafter Jensen, Takeovers].

150. Bengt Holmstrom \& Steven N. Kaplan, Corporate Governance and Merger Activity in the United States: Making Sense of the 1980s and 1990s, 15 J. ECON. PERSP., Spring 2001, at 121, 129; Jensen, Takeovers, supra note 149, at 28 (noting that this cash flow was referred to as "free cash flow").

151. Frank Dobbin \& Dirk Zorn, Corporate Malfeasance and the Myth of Shareholder Value, in 17 Political Power AND Social TheORY 179, 183 (Diane E. Davis ed., 2005); Jensen, Takeovers, supra note 149, at 28-29.

152. See infra text accompanying notes $201,243$.

153. See supra text accompanying note 149 .

154. See KHURANA, supra note 148, at 318-19; Jensen, Takeovers, supra note 149, at 29.

155. See Frank Dobbin \& Jiwook Jung, The Misapplication of Mr. Michael Jensen: How Agency Theory Brought Down the Economy and Why It Might Again, in 30B MARKETS on Trial: The ECONOMIC Sociology OF THE U.S. FinANCIAL CRISIS: PART B 29, 35 (Michael Lounsbury \& Paul M. Hirsch eds., 2010); Jensen, Takeovers, supra note 149, at 28-29; Jensen \& Meckling, supra note 137, at 323, 353 (including stock options).

156. Holmstrom \& Kaplan, supra note 150, at 121.

157. Gerald F. Davis \& Suzanne K. Stout, Organization Theory and the Market for Corporate Control: A Dynamic Analysis of the Characteristics of Large Takeover Targets, 1980-1990, 37 ADMIN. SCI. Q. 605, 605 (1992).

158. Lynn E. Browne \& Eric S. Rosengren, The Merger Boom: An Overview, in THE Merger Boom: Proceedings of a Conference Held at Melvin Village, New Hampshire 
of hostile takeovers, high debt levels, and financial innovation in the form of junk bonds. ${ }^{159}$ The Reagan Administration's lax antitrust enforcement that made horizontal mergers less likely to be challenged, cuts in corporate tax rates that provided capital for mergers, and inflation that distorted firm values also facilitated this merger wave. ${ }^{160}$ Those firms with managers who adopted the shareholder value maximization conception reorganized and those that did not became targets. ${ }^{161}$ For this reason managers had the incentive to embrace the shareholder value maximization conception of corporate governance.

However, the evidence does not suggest that managerial self-interest played a primary role in the formation of conglomerates and the problems these firms experienced by the late 1970s. ${ }^{162}$ This suggests that the foundation of the shareholder value maximization conception grounded in agency theory is somewhat shaky and accordingly, also its prescriptions. The following analysis demonstrates why this is the case.

First, the stock markets in the 1960s and early 70 s responded favorably to conglomerate mergers. ${ }^{163}$ They were "fashionable" during this time period. ${ }^{164}$ Firm managers sought to increase the profitability and stability of their firms through conglomerate mergers and were rewarded with higher stock prices. ${ }^{165}$ For example, on the announcement of diversifying mergers, bidders

OCtOBER 1987, at 1, 2 (Lynn E. Browne \& Eric S. Rosengren eds., 1987); Davis et al., The Decline and Fall of the Conglomerate Firm, supra note 125, at 548, 559, 561-62; see Ocasio \& Kim, supra note 125, at 538 (discussing the general acceptance by the late $1980 \mathrm{~s}$ of the view that firms should focus on their core competencies).

159. Holmstrom \& Kaplan, supra note 150, at 121, 124-27.

160. Dobbin \& Zorn, supra note 151, at 185-86; Fligstein \& Markowitz, supra note 1, at 187 (explaining that high inflation meant that "real assets (i.e., land, buildings, tools) were increasing in value and at the same time, high interest rates meant that the stock market produced lower returns than other forms of investment," such as bond markets); Thomas E. Kauper, The Antitrust "Revolution" and Small Business: On "The Turnpike to Efficiencyville," in LAW AND Class in AMERICA: TRENDS Since THE COLD WAR 120, 130 31, 135 (Paul D. Carrington \& Trina Jones eds., 2006); see Kovacic \& Shapiro, supra note 44 , at 52-55.

161. Fligstein \& Markowitz, supra note 1, at 194, 203.

162. See infra text accompanying notes 163-221.

163. See Holmstrom \& Kaplan, supra note 150, at 131; R. Glenn Hubbard \& Darius Palia, A Reexamination of the Conglomerate Merger Wave in the 1960s: An Internal Capital Markets View, 54 J. FIN. 1131, 1131-32 (1999); John G. Matsusaka, Takeover Motives During the Conglomerate Merger Wave, 24 RAND J. ECON. 357, 358 (1993).

164. Hurley, supra note 130, at 185.

165. Hubbard \& Palia, supra note 163, at 1131-32, 1134. 
experienced abnormal positive returns. ${ }^{166}$ These returns were higher for conglomerate mergers than related-product mergers. ${ }^{167}$ Thus managers were not simply furthering their self-interest in forming conglomerates. ${ }^{168}$ They were responding to signals from the stock market.

Second, industry leaders, the business press and leading economist, such as Oliver Williamson and Armen Alchian, expounded at that time on the efficiencies to be derived from conglomerates, including efficiencies in capital access, capital allocation, risk spreading, and managerial accountability. ${ }^{169}$ Conglomerates would enable small and medium-sized firms, who became divisions of conglomerates, greater access to capital and assist in their survival. ${ }^{170}$ Firms with high cash flow volatility that could not access public markets directly could do so indirectly by becoming part of a conglomerate that had access to public markets. ${ }^{171}$ The pooling of profits from these divisions would also allow the central office to make

166. Id. at 1131 .

167. Id. at $1131-32$.

168. See Neil Fligstein \& Peter Brantley, Bank Control, Owner Control, or Organizational Dynamics: Who Controls the Large Modern Corporation?, 98 AM. J. Soc. 280, 287-88, 300, 303 (1992) (finding "no evidence that diversification [was] undertaken by managers who act[ed] on their own behalf and against the interests of owners"); Matsusaka, supra note 163 , at $357-58,364 \&$ tbl.1 (finding that shareholders benefited by the conglomerate merger wave in the late 1960s and that markets appeared to dislike "takeovers that were motivated to discipline target management").

169. Dobbin \& Zorn, supra note 151, at 185; see Hurley, supra note 130, at 185-94. For a summary of studies modeling diversifying as a value-enhancing strategy, see Jose Manuel Campa \& Simi Kedia, Explaining the Diversification Discount, 57 J. FIN. 1731, 1735 (2002). Economists discussed the informational and monitoring advantages of conglomerates, including the advantages of internal capital allocations when compared to external capital markets. E.g., OLIVER E. WILLIAMSON, MARKETS AND HIERARCHIES: ANALYSIS AND ANTITRUST IMPLICATIONS 158-59, 161-62, 171-75 (1975); Armen A. Alchian, Corporate Management and Property Rights, in ECONOMIC POLICY AND THE REGULATION OF CORPORATE SECURITIES 337, 337-60 (Henry G. Manne ed., 1969). For a discussion of the advantages and disadvantages of firm diversification, see Campa \& Kedia, supra note 169, at 1734-35.

170. See Hurley, supra note 130, at 189-90. CEO of the conglomerate International Telephone and Telegraph, Harold Geneen, discussed how conglomerates would provide access to capital and management expertise:

In picking and choosing what companies to acquire, [we considered] our expertise in management and [whether] our access to greater financial resources add something to that particular company. In most instances, we kept on the same management and introduced the company's managers to the ITT system of business plans, detailed budgets, strict financial controls, and face-to-face General Managers Meetings.

Hubbard \& Palia, supra note 163, at 1133 (quoting Harold Geneen \& Alvin Moscow, MANAGING 206-07 (1984)).

171. See Zsuzsanna Fluck \& Anthony W. Lynch, Why Do Firms Merge and Then Divest? A Theory of Financial Synergy, 72 J. Bus. 319, 341-42 (1999). Additional financial benefits claimed for conglomerates include the greater ease of shifting assets among constituent firms compared to independent firms, a greater debt capacity, and the ability to benefit from tax loss benefits. Id. at 324-25. 
capital available to those divisions with the most attractive business opportunities. ${ }^{172}$ The informational and monitoring advantages of allocating capital internally within conglomerates were viewed as overshadowing the advantages of accessing external capital markets, possibly due to the less developed capital markets during this period. ${ }^{173}$ That capital access was an important motive for mergers in the 1960s is shown by a study that found that highest bidder returns were from mergers of financially constrained targets with financially unconstrained buyers. ${ }^{174}$ Conglomerate mergers were more likely than product-related mergers to involve the acquisition of financially distressed firms. ${ }^{175}$ Conglomerates also moderate risk in times of economic downturn "for each unit is buoyed by its stronger units," contributing to the stability of the firm. ${ }^{176}$

It was also generally believed that profits would be enhanced by the managerial advantages of conglomerates. For example, superior management teams could be deployed as needed in the various divisions, less able managers removed, and cost savings gained by having some common functions performed at the central corporate level, such as advertising, research and development, and finance. ${ }^{177}$ An executive explained in 1968:

I would say that it would be worthwhile for people to sit down and study the
operating margins of companies that Teledyne, Litton [and Monogram Industries]
have taken over with their bright young management teams. I would submit that
you will find sharp increases in efficiency. I've seen this in many cases, and even
though these businesses may be in disparate fields, the ingredient of more aggressive,
sophisticated management with use of new techniques has made a positive contribution.
I submit that many of these conglomerates will be considerably stronger in a period
of recession than the individual units would have been left on their own. ${ }^{178}$

Third, contributing to the poor performance of firms in the 1970s were macroeconomic and industry shocks for which managers were not responsible. These included the unsettling abandonment of the Bretton Woods system

172. See Hurley, supra note 130, at 189-91 (noting that divisions would not only need to compete with other divisions for resources, but also with outside target companies that its firm may acquire that offer better investment opportunities).

173. See WILLIAMSON, supra note 169, at 161-62 (discussing the advantages of internal information); Hubbard \& Palia, supra note 163, at 1138.

174. See Hubbard \& Palia, supra note 163, at 1131.

175. See id. at 1147 .

176. Dobbin \& Jung, supra note 155 , at 45.

177. Hurley, supra note 130, at 191-93.

178. Id. at 188 (quoting Samuel N. Seidman, The Role of the Investment Banker in Corporate Consolidation, in PROCEEDINGS OF THE CONFERENCE ON MERGERS AND ACQUISITIONS 82, 98 (Allan Easton \& Arnold Broser eds., 1970)). 
of fixed currency exchange rates in the early 1970s, the oil shocks during the 1970s - the 1973 OPEC embargo and the 1978-79 Iranian oil-export cutoff - that particularly affected the oil industry, high inflation, deregulation in such industries as airlines and trucking, and fierce international competition from Japan and Europe. ${ }^{179}$ For example, one study of 3,660 firms in 46 industries found that takeovers and restructuring in the 1982 to 1989 period were clustered in those industries that experienced greatest economic shocks. ${ }^{180}$ Thus, broad-based fundamental factors contributed to the takeovers and restructuring of conglomerates formed in the 1960s and 70s. ${ }^{181}$

Fourth, agency theorists criticized managers of conglomerates for investing in negative cash flow projects and for their failure to downsize their firms. ${ }^{182}$ However, a retrospective study of the 1980s merger wave has examined the use of free cash flow by managers of target firms. ${ }^{183}$ There is evidence that target firms did not make significantly different capital expenditures than their industry peers; this was also true for targets of hostile takeovers and firms that went private. ${ }^{184}$ There is some evidence of overinvestments by large firm targets and firms in the oil and gas industry, with the large firm findings driven by oil and gas targets. ${ }^{185}$ However, the premiums in 1980s takeovers do not appear to be related to industry or firm overinvestment even for large targets, indicating that overinvestments by managers may not have motivated these acquisitions. ${ }^{186}$

Fifth, downsizing was not the norm in the 1960s and 70s. ${ }^{187}$ As Professor Michael Useem explains, "While diversification had been a hallmark of

179. See Cheffins, Corporate Governance, supra note 16, at 735; Fligstein \& Brantley, supra note 168, at 303; Fligstein \& Markowitz, supra note 1, at 187, 189, 204-05; Gomory \& Sylla, supra note 115, at 107; Ocasio \& Kim, supra note 125, at 538 (discussing the impact of competition on a search for new theories of good corporate governance).

180. Mark L. Mitchell \& J. Harold Mulherin, The Impact of Industry Shocks on Takeover and Restructuring Activity, 41 J. FIN. ECON 193, 210-11, 211 tbl.7, 221 (1996) (taking into account shocks such as changes in sales and employment, volatile oil prices, deregulation, and innovation in junk bond financing).

181. Additionally, antitrust policy and the cost of capital were important factors. See Margaret Blair, CORP. GOVERNANCE, http:/www.corpgov.net/education/conversations/ margaret-blair/ [https://perma.cc/NFE5-YR3B]. The cost of capital is dependent on macroeconomic factors, such as interest rates and tax rates. See Fligstein \& Markowitz, supra note 1, at 193.

182. See Henri Servaes, Do Takeover Targets Overinvest?, 7 REV. FIN. STUD. 253, 255

(1994). For a summary of mixed evidence regarding this theory, see id. at 254.

183. See id.

184. See id. at $262-65$.

185. See id. at 265, 275. See also Jensen, supra note 142, at 327 (discussing overinvestment in firms in oil and gas industry only).

186. See Servaes, supra note 182, at 269.

187. See Art Budros, A Conceptual Framework for Analyzing Why Organizations Downsize, 10 ORG. SCI. 69, 70, 78 (1999) (stating that before the 1980s downsizing was a temporary response to economic conditions, but became "in fashion" by the mid-1980s 
good management during the 1960s, shedding unrelated businesses had become the measure during the 1980s and 1990s." 188 For example, because firms that were larger were viewed as more successful in the 1960s, any workforce downsizing that occurred tended to be limited in size and temporary in nature. ${ }^{189}$ The reverse was the case in the 1980s. ${ }^{190}$ Since the 1980 s, stock prices go up when a firm as part of its restructuring fires its workers. ${ }^{191}$ Focusing on core competencies, cutting costs, and decreasing corporate assets to enhance the firm's return on assets win stock market approval. ${ }^{192}$ Managers are not solely to blame for these changing norms that are based on rationalized responses to the demands of different times. For the most part, in both time periods, in the 1960s and 70s and since the 1980s, managers responded to different conceptions of good corporate governance and the social reflection of these conceptions in stock market prices.

and thereafter became "business-as-usual"); Jiwook Jung, Shareholder Value and Workforce Downsizing, 1981-2006, 93 SOC. ForCES 1335, 1336 (2015) ("Before the 1980s, managers engaged in downsizing only reluctantly because, at that time, expanding the size of a firm was the hallmark of successful management. The recent prevalence of downsizing suggests that managers have changed their attitude toward downsizing and have embraced it as a value-enhancing strategy").

188. Michael Useem, InVEStor Capitalism: How Money Managers ARE Changing THE FACE OF CORPORATE AMERICA 153 (1996).

189. See Budros, supra note 187, at 70 ("Fundamental differences distinguish [permanent] layoffs from those executed before the 1980s. Although deliberate, the latter tended to occur during short-term economic slumps and thus tended to be temporary in nature. The aim was not to create smaller organization (downsizing through layoffs), but to adjust employment levels downward until business conditions recovered." (citing Kim S. Cameron et al., Downsizing and Redesigning Organizations, in ORGANIZATIONAL Change and Redesign: Ideas and Insights for Improving Performance 19, 20-21 (George P. Huber \& William H. Glick eds., 1993); Wayne F. Cascio, Downsizing: What Do We Know? What Have We Learned?, 7 ExECuTIVE 95, 95, 99 (1993) (noting that "[i]n many cases ... the gains [from downsizing] are short-lived, for despite all of the layoffs, automation, and just-in-time inventory management, U.S. nonfarm productivity rose a scant $1.2 \%$ a year during the 1980 s. That's almost no improvement from the 1970 s.")).

190. See Davis et al., The Decline and Fall of the Conglomerate Firm, supra note 125, at 548; Fligstein \& Markowitz, supra note 1, at 189-90.

191. See USEEM, supra note 188, at 146 (noting that the stock prices go down, however, when downsizing is merely cost cutting and not part of a general restructuring); Gerald F. Davis, Can an Economy Survive Without Corporations? Technology and Robust Organizational Alternatives, 30 ACAD. MGMT. PERSP. 129, 133 (2016); Kent Greenfield, Reclaiming Corporate Law in a New Gilded Age, 2 HARV. L. \& PoL'y REV. 1, 12 (2008); Jung, supra note 187, at 1338 .

192. See Fligstein \& Markowitz, supra note 1, at 191-94; Zorn, supra note 4, at 348. 
Sixth, while conglomerates have been viewed as problematic due to the diversification discount, ${ }^{193}$ studies have shown that the act of diversifying does not necessarily explain the discount. ${ }^{194}$ For example, one study found that one-half of the discount for business segment-increasing firms was due to the addition of divisions that were already discounted. ${ }^{195}$ Thus, there are systematic differences between conglomerate divisions and typical stand-alone firms to which they were benchmarked in previous studies. ${ }^{196}$ Moreover, recent studies have questioned the methodology used to compare conglomerates to stand-alone firms that raise questions about "whether the conglomerate discount is a real empirical phenomenon or an artifact of the measurement process." 197 There is also contrary authority to the traditional view ${ }^{198}$ that $1960-70$ s conglomerates performed worse than their more focused counterparts. ${ }^{199}$ Even if they performed poorly, claims that

193. For a review of the literature on the diversification discount, see generally Vojislav Maksimovic \& Gordon M. Phillips, Conglomerate Firms, Internal Capital Markets and The Theory of the Firm, 5 ANN. REV. Fin. ECON. 225 (2013).

194. John R. Graham et al., Does Corporate Diversification Destroy Value?, 57 J. FIN. 695, 697 (2002) (summarizing studies); see Campa \& Kedia, supra note 169, at 173233 (stating that although conglomerates have been discredited due to a diversification discount, the discount may be related less to diversification than the characteristics of firms that decide to diversify). The study found that when exogenous characteristics were controlled for, "the diversification discount always drops, and sometimes turns into a premium." Campa \& Kedia, supra note 169 , at 731.

195. Graham et al., supra note 194, at 715-17.

196. Id. at 710,718 .

197. Maksimovic \& Phillips, supra note 193, at 228. See also John E. Hund et al., A Manufactured Diversification Discount (Dec. 16, 2016), http://ssrn.com/abstract=2535017 [https://perma.cc/SSN3-4DXD].

198. Bernard S. Black, The Value of Institutional Investor Monitoring: The Empirical Evidence, 39 UCLA L. REV. 895, 903-05 (1992) ("The evidence that corporate diversification reduces company value is consistent and collectively damning."); Davis et al., The Decline and Fall of the Conglomerate Firm, supra note 125, at 548 (explaining that conglomerates were generally viewed as a collective error made by U.S. business persons) (citing Your Obedient Servant, ECONOMIST, Apr. 27, 1991, at 43, 44).

199. See Pieter T. Elgers \& John J. Clark, Merger Types and Shareholder Returns: Additional Evidence, 9 FIn. MGMT. 66, 72 (1980) (finding that for the period 1956-1975 "conglomerate mergers showed superior wealth effects for both buyer and seller shareholders, compared to non-conglomerate mergers"); Fligstein \& Brantley, supra note 168, at 300 (stating that in the 1970s "firms with product-unrelated strategies did no worse or no better than firms with product-dominant strategies"). There is also contrary authority for the view that poorly performing conglomerates explain the 1980s merger wave. See, e.g., Dobbin \& Jung, supra note 155, at 44 (discussing mixed evidence on the efficiency of deconglomeration); Holmstrom \& Kaplan, supra note 150, at 131 (noting that "empirical results suggest that deconglomeration played a role in the 1980 s takeovers, but was probably not the primary driver"); Belen Villalonga, Does Diversification Cause the Diversification Discount?, 33 FIN. MGMT. 5 (2004) (finding that diversification does not destroy value for 1978-97 mergers). There is considerable controversy over the benefits and costs of conglomerates and whether conglomerates add value. See, e.g., Campa \& Kedia, supra note 169, at 1734-35 (explaining 
the primary cause was managerial self-interest falter if managers merely overestimated their ability to oversee widely diversified businesses at least with the communications and computer technology available to them at the time. ${ }^{200}$

Seventh, the shift towards institutional share ownership in firms contributed to the takeovers of the 1980 s and the busting up of conglomerates. ${ }^{201}$ The ownership of large blocks of stock by institutional investors enabled firms to be bought and sold with greater ease by hostile takeover firms. ${ }^{202}$ Institutional investors were large investors in buyout funds and junk bonds. ${ }^{203}$ Junk bonds that are risky, high yield bonds were popularized by Drexel Burnham Lambert and were a currency of choice for takeovers during this period, enabling large firms to be taken over by smaller, highly leveraged firms. ${ }^{204}$ These developments were foreshadowed by various events in the 1970s that were outside of firm managers' control. For example, the passage of the Employee Retirement Income Security Act of 1974 created funding requirements for firms' retirement plans that increased the institutional investors' pool of assets to invest. ${ }^{205}$ Moreover, the abolition of fixed brokerage commission rates, which became effective on May 1, 1975 (May Day), increased competition among institutional investors and stock turnover, resulting in investors focusing more on stock appreciation rather than dividends. ${ }^{206}$ Additionally, the deconstruction of the Bretton Wood system

the benefits and costs of conglomeration); Maksimovic \& Phillip, supra note 193 (summarizing studies on conglomerates).

200. See Lazonick \& O'Sullivan, supra note 142, at 15.

201. Holmstrom \& Kaplan, supra note 150, at 132.

202. Id.

203. UsEeM, supra note 188, at 2, 25, 26; Holmstrom \& Kaplan, supra note 150, at 132; Lazonick \& O'Sullivan, supra note 142, at 16 (discussing the role of takeover specialty firms); Batt \& Appelbaum, supra note 111, at 9-10, 12. A significant takeover firm during this period was Kohlberg Kravis Roberts \& Co., which popularized the use of leveraged buyouts. Batt \& Appelbaum, supra note 111, at 11.

204. Dobbin \& Zorn, supra note 151, at 185; Holmstrom \& Kaplan, supra note 150 , at 125 .

205. Pavlos E. Masouros, Corporate Law and Economic Stagnation: How Shareholder Value and Short-Termism Contribute to the Decline of the WeStern ECONOMIES 82-83 (2013); Batt \& Appelbaum, supra note 111, at 9 (discussing changes in ERISA requirements in 1974 and 1978 and changes in regulations of savings and loan institutions); Lazonick \& O'Sullivan, supra note 142, at 17 (discussing changes with ERISA that allowed pension funds and insurance companies to invest in equities and risky securities, such as junk bonds, and the Garn-St. Germain Depository Institutions Act of 1982 that allowed savings and loan institutions to invest in junk bonds).

206. MASOUROS, supra note 205 , at 81 . 
of fixed currency exchange rates in the early 1970s introduced "greater instability and unpredictability in financial markets" leading to more short-term investment strategies by investors. ${ }^{207}$

Institutional investors also played a role in de-diversification in the $1980 \mathrm{~s}$ because they viewed it as their role rather than the firm's role to diversify portfolios. $^{208}$ They did not need firms to perform this function. As far as investors were concerned, it was not necessary for single firms to reduce risk by becoming conglomerates when they as shareholders could easily reduce their risk by diversifying their individual portfolios. It was also much easier for institutional investors to perform the diversifying function when firms were single product firms. ${ }^{209}$

Additionally, securities analysts became increasingly important in evaluating stock in the $1980 \mathrm{~s}^{210}$ From the late 1970 s to the early 1990 s the number of security analysts following typical firm leaders increased from eight to eighteen. ${ }^{211}$ Analysts specialized by industry and were therefore less likely to follow conglomerates. ${ }^{212}$ Conglomerates were difficult for these specialists to value. ${ }^{213}$ Evidence shows that firms followed by fewer analysts experienced lower stock valuations. ${ }^{214}$ Managers in the 1960s and 70s were not responsible for these developments. Firms were motivated to de-conglomerate to stimulate institutional investor interest, increase analysts' coverage, and avoid hostile takeovers. $^{215}$

Finally, a short-termism orientation most likely contributed more than managerial self-interest to the poor performance of firms in the managerial era of the 1960s and 70s. In 1980 two Harvard Business School professors,

\footnotetext{
207. Id. at 57-59.

208. Dobbin \& Zorn, supra note 151, at 189-90.
}

209. See id. at 190. From 1981 to 1987, Fortune 500 firms with large blocks of stock held in a few hands were more likely to decrease their diversification than other firms. USEEM, supra note 188 , at 153 .

210. See Dobbin \& Zorn, supra note 151, at 190-91.

211. Id. at 191 (citing Zorn et al., Managing Investors: How Financial Markets Reshaped the American Firm, in The Sociology of FinANCIAL MARKeTs 269, 275 (Karin Knorr Cetina \& Alexandru Preda eds., 2005)).

212. Useem, supra note 188, at 153; Dobbin \& Zorn, supra note 151, at 191.

213. Dobbin \& Zorn, supra note 151, at 191.

214. See Ezra W. Zuckerman, The Categorical Imperative: Security Analysts and the Illegitimacy Discount, 104 AM. J. Soc. 1398, 1398 (1999) (finding that from 1985 to 1994 , "the stock price of an American firm was discounted to the extent that the firm was not covered by securities analysts who specialized in its industries"); see also Ezra W. Zuckerman, Focusing the Corporate Product: Securities Analysts and De-Diversification, 45 ADMIN. SCI. Q. 591, 614-15 (2000) (concluding that investors pressured firms to abide by "systems of classification, currently dominated by industry-based categories," so that "change [in] a firm's corporate strategy [could not] be reduced to efficiency-based considerations").

215. Dobbin \& Jung, supra note 155, at 42-43; Dobbin \& Zorn, supra note 151, at 191. 
Professors Hayes and Abernathy, wrote an influential article, Managing Our Way to Economic Decline, sending shock waves through the business community. ${ }^{216}$ They set forth graphs and charts showing the rise of finance presidents and the dramatic decline in productivity and long- term investments by U.S. firms when compared to their foreign counterparts. ${ }^{217}$ They pointed to the analytical detachment of top managers from the actual operations of their firms. ${ }^{218}$ They criticized managers' use of short-term financial controls and their focus on making cost reductions rather than longterm investments. ${ }^{219}$ They were concerned about the selection of what they called "pseudoprofessional[s]" or outsiders for top managerial positions who had no experience in the particular industry but operated the business through the "strict application of financial controls, portfolio concepts, and market-driven strategy." 220 They also referred to the merger mania of the $1960 \mathrm{~s}$ and 70s. ${ }^{221}$ They claimed that it was only natural that finance and legal presidents would focus on financial activities and the quicker results associated with mergers and acquisitions rather than the more unglamorous, arduous task of building in-house technology. ${ }^{222}$

\section{The Emergence of the Shareholder Value Maximization Conception and Disaggregation}

The portfolio management approach declined in legitimacy with the criticisms of conglomerates. ${ }^{223}$ Consequently, financial presidents lost some ground in the 1980s in favor of presidents with operating backgrounds. ${ }^{24}$ One

216. Robert H. Hayes \& William J. Abernathy, Managing Our Way to Economic Decline, HARV. Bus. REV., July-Aug. 1980, at 67.

217. Id. at 69, Ex. I-II, 70 Ex. III, 75 Ex. VI; see also Ocasio \& Kim, supra note 125, at 537-38. In the 100 largest U.S. firms from 1959-1979, the percentage of finance presidents increased from $16.1 \%$ to $27.5 \%$ and generalist from $10.4 \%$ to $15.8 \%$. Fligstein, The Intraorganizational Power Struggle, supra note 9, at 47 tbl.2. Lawyer presidents were $6.7 \%$ in 1979 . Id.

218. Hayes \& Abernathy, supra note 216, at 68.

219. See id. (referring to this approach as "competitive myopia"); Ocasio \& Kim, supra note 125 , at 538 .

220. Hayes \& Abernathy, supra note 216, at 74.

221. See id. at $75-76$.

222. Id. at 75-76. They also believed that U.S. firms, by not focusing on core competencies, were not able to compete with their more focused, foreign competitors. See id. at 76.

223. Ocasio \& Kim, supra note 125, at 556-57.

224. See id. at 547-48, 550, 556-57 (finding that finance presidents in large U.S. manufacturing firms decreased from $22 \%$ in 1981 to $16 \%$ in 1992). The multidivisional form and unrelated diversification important in the 1960s and 1970s to explain the rise of 
observer stated, "corporate reorganizations associated with the rise of stockholder interests typically involve large-scale changes in either production or operations, strategies typically associated with CEOs from production or operations backgrounds." 225 However, firms engaging in large numbers of mergers and acquisitions were as likely to select finance CEOs as operations CEOs. ${ }^{226}$ Moreover, over time MBA identities blurred the distinction between operating and finance presidents ${ }^{227}$ and, additionally, firms increasingly created CFO positions. By 2000, 80\% of the 400 largest firms had CFOs, a dramatic increase from zero in $1964 .{ }^{228}$ With the increasing acceptance of the shareholder value maximization conception, the responsibilities of CFOs expanded to deal with investor relations and financial analysts, and to manage stock market expectations. ${ }^{229}$

Moreover, firms selected outsider CEOs more frequently as managerial capitalism was replaced with investor capitalism. ${ }^{230}$ While less than $20 \%$ of CEO succession events resulted in outsider CEOs in the early 1980s, this percentage increased to $50 \%$ in the mid-1990s and remained in the range of $30 \%$ to $40 \%$ thereafter. ${ }^{231}$ The explanation given for the selection of outsiders is the belief that insiders have irrational connections to people and products. ${ }^{232}$ Thus, downsizing that has become the strategy of choice since the 1980s is furthered by the choice of outsiders. The selection of outsiders is intended to "send[] a strong message [to stock markets] that the firm is firmly committed" to initiate and implement strategic changes. ${ }^{233}$ Firm-specific knowledge is viewed of less importance in the selection of an outsider CEO. ${ }^{234}$ Thus, promotion to the CEO position from within became less the norm as boards looked outward often to find charismatic

\footnotetext{
finance CEOs were no longer associated with finance presidents during the 1980s and 1990 s. Id. at 552, 556. One study indicates that finance presidents were unfairly judged. See Fligstein \& Brantley, supra note 168, at 303 (finding that "financially oriented executives who ran diversified firms and engaged in mergers outperformed their brethren, on the average"). When a sufficiently large number of firms choose to adopt a strategy, the president's background is less important to a firm's choice of strategy. See Fligstein, The Structural Transformation of American Industry, supra note 4, at 324.

225. Ocasio \& Kim, supra note 125 , at 539.

226. Id. at $550-52$.

227. Id. at 557 .

228. Zorn, supra note 4, at 346.

229. See id. at 352,362 .

230. See Jiwook Jung, Political Contestation at the Top: Politics of Outsider Succession at U.S. Corporations, 35 ORG. STUD. 727, 729 (2014) (discussing how this is associated with the power of institutional investors and outsider-dominated boards of directors).

231. Id. at 729-30, 730 fig.1.

232. See id. at 729 .

233. Id.

234. See id.
} 
leaders with a new vision for the future of their firms and who would receive the approbation of investors, analysts, and the business press. ${ }^{235}$

Many managers initially opposed hostile takeovers that were believed by agency theorists to enhance shareholder value by displacing bad managers. ${ }^{236}$ Managers utilized defensive tactics and were successful in urging states to adopt anti-takeover statutes, including constituency statutes that permitted managers to act in the interests of firm stakeholders. ${ }^{237}$ While managers' success in defending anti-takeover devices was mixed, the use of these devices made hostile takeover more costly. ${ }^{238}$ However, by the 1990s managers in varying degrees, and more significantly their boards of directors, ${ }^{239}$ came to accept the legitimacy of the new shareholder value maximization conception of corporate governance. ${ }^{240}$ Merger activity continued in the 1990s, although with less hostility. ${ }^{241}$ Some suggest that substantial compensation packages with large amounts of stock options influenced this change. ${ }^{242}$ However,

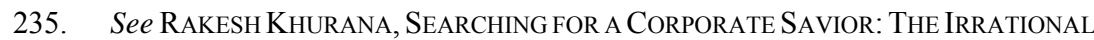
QUEST FOR CHARISMATIC CEOs 71, 78-79 (2002); Khurana, supra note 113, at 62.

236. See Easterbrook \& Fischel, supra note 141, at 1168-69; Daniel R. Fischel, The Corporate Governance Movement, 35 VAND. L. REV. 1259, 1264 (1982).

237. See Brian R. Cheffins, The History of Corporate Governance, in THE OXFORD HANDBOOK OF CORPORATE GOVERNANCE 46, 52-53 (Mike Wright et al. eds., 2013) [hereinafter Cheffins, The History of Corporate Governance]; see also Lynne L. Dallas, The New Managerialism and Diversity on Corporate Boards of Directors, 76 TuL. L. REV. 1363, 1374 n.31 (2002) [hereinafter Dallas, The New Managerialism] (noting defensive tactics utilized by managers and statutory limitations on corporate takeovers).

238. A complex jurisprudence developed. The Supreme Court struck down the first generation of state anti-takeover statutes in Edgar v. MITE Corp., 457 U.S. 624, 646 (1982). However, the Court upheld the second generation of state anti-takeover statutes in CTS Corp. v. Dynamics Corp., 481 U.S. 69, 70 (1987). The Delaware courts gave managers considerable discretion in utilizing defensive tactics under an enhanced business judgment rule. E.g., Unocal Corp. v. Mesa Petroleum Co., 493 A.2d 946, 946 (Del. 1985). However, the Delaware courts required directors to maximize shareholder value in some situations. E.g., Revlon, Inc. v. MacAndrews \& Forbes Holdings, Inc., 506 A.2d 173, 173 (Del. 1986). States adopted a variety of anti-takeover statutes, such as control share acquisition provisions, fair price provisions, and business combination statutes. See generally Emiliano M. Catan \& Marcel Kahan, Law and Finance of Antitakeover Statutes, 68 STAN. L. REV. 629 (2016).

239. Dallas, The New Managerialism, supra note 237, at 1376 (summarizing a 1999 survey of directors of major U.S. firms that confirmed a "cultural' change" on boards of directors in their recognition of their duty owed to shareholders (quoting KORN/FERRY INT'L, 26TH ANNUAL BOARD OF DiRECTORS STUDY 5 (1999))).

240. Dobbin \& Zorn, supra note 151, at 181, 183; Cheffins, The History of Corporate Governance, supra note 237, at 53, 56.

241. Holmstrom \& Kaplan, supra note 150, at 132-33.

242. E.g., id. at 122. 
the firm environment had also changed. Institutional stock ownership increased from $30 \%$ to $50 \%$ from 1980 s to $1996 .{ }^{243}$ With the legitimacy provided by agency theory, laws and practices also were adopted that enhanced the power of institutional investors who demanded high returns. ${ }^{244}$ The adoption of the shareholder value maximization conception is reflected in a 1999 survey of directors of major U.S. firms confirming a " cultural' change" on boards of directors in recognizing their duty owed to shareholders. ${ }^{245}$

Structurally, the busting up of the conglomerates heralded a period, accelerated during the 1990s and continuing today, of disaggregation, including vertical disintegration and outsourcing by firms, in order to maximize shareholder value. ${ }^{246}$ Approximately one-fourth of Fortune 500 firms disappeared as independent entities in the 1980s mainly due to deconglomeration. ${ }^{247}$ By the late 1980s managers of firms in general believed they should focus on their firm's core business. ${ }^{248}$

Thus, managers at many major firms viewed good corporate governance as subcontracting out all but core functions to subsidiaries or outside firms. ${ }^{249}$ They sought to decrease their uncertainty by acquiring flexibility in an environment of rapidly changing technology, financial markets, and consumer tastes. $^{250}$ Moreover, they sought to impress the stock markets and activist shareholders who favored firms that had high returns on their tangible

243. Paul Gompers \& Andrew Metrick, Institutional Investors and Equity Prices, 116 Q.J. ECON. 229, 237 fig.1 (2001).

244. See Coffee, Jr. \& Palia, supra note 147, at 562-70; Kahan \& Rock, supra note 147 , at 1007-19.

245. Dallas, The New Managerialism, supra note 237, at 1376 (quoting KORN/FERRY INT'L, supra note 239 , at 5 ).

246. See Gerald F. Davis et al., Political Agency and the Responsibility Paradox: Multinationals and Corporate Social Responsibility, in CONTEMPORARY POLITICAL AGENCY: THEORY AND PRACTICE 93, 98 (Bice Maiguashca \& Raffaele Marchetti eds., 2013) [hereinafter Davis et al., Political Agency]; Norman Jones, The Hollow Corporation, Bus. WK., Mar. 3,1986 , at 57,58 .

247. Davis et al., Decline and Fall of the Conglomerate Firm, supra note 125, at 561-62.

248. Id.; see Ocasio \& Kim, supra note 125, at 538) (discussing the general acceptance by the late 1980 s of the view that firms should focus on their core competencies); see also Batt \& Appelbaum, supra note 111, at 11-12 (noting that 1980s mergers "were primarily horizontal mergers" and discussing the decline in firm diversification).

249. See N. Anand \& Richard L. Daft, What Is the Right Organizational Design?, 36 ORganizational Dynamics 329, 335-36, 335 tbl.2, 337 tbl.3 (2007); Rosabeth Moss Kanter, The Future of Bureaucracy and Hierarchy in Organizational Theory: A Report from the Field, in Social THEORY FOR A CHANGING SocieTy 63, 68 (Pierre Bourdieu \& James S. Coleman eds., 1991) (referring to a "switchboard" firm); S. Tully \& T. Welsh, The Modular Corporation, ForTune, Feb. 8, 1993, at 106.

250. See Larry Hirschhorn \& Thomas Gilmore, The New Boundaries of the "Boundaryless" Company, Harv. Bus. Rev., May-June 1992, at 104, 104-05; Jones, supra note 246, at 58. 
assets. ${ }^{251}$ Thus, they had an incentive to shed assets. Rather than growth, previously valued by firms, shareholder value maximization resulted in firms adopting cost cutting measures to meet or beat the quarterly earnings expectations of the stock market.

By engaging in contracting out all but core functions to outside firms, many large firms have become "hubs" of vast networks, essentially functioning as management or systems integration firms, exemplifying a process often referred to as "Nikefication." 252 These networks consist of suppliers, dealers and even competitors - with whom they engage in joint research and product development - through partnerships, joint ventures, and strategic alliances. ${ }^{253}$ The core functions they retain are often marketing, finance, and sometimes product design and $R \& D{ }^{254}$ They often manage intangible assets such as brand names, trademarks, patents, and research capabilities. $^{255}$ For example, Nike focuses on design and marketing. ${ }^{256}$ Coca-Cola Company primarily engages in managing its brand name. ${ }^{257}$ As for Hewlett-Packard Company, one of its vice presidents explains: "We own all of the intellectual property; we farm out all of the direct labor. We don't need to screw the motherboard into the metal box and attach the ribbon cable" to create an HP computer. ${ }^{258}$ In some industries

251. See Benito Arruñada \& Xosé H. Vázquez, When Your Contract Manufacturer Becomes Your Competitor, HARV. Bus. REV., Sept. 2006, at 135, 139-40; Gerald F. Davis, The Rise and Fall of Finance and the End of the Society of Organizations, 23 ACAD. MgMt. PERsP. 27, 34 (2009) [hereinafter Davis, The Rise and Fall of Finance].

252. See Gerald F. Davis, What Might Replace the Modern Corporation? Uberization and the Web Page Enterprise, 39 SeAtTLE U. L. ReV. 501, 510-11 (2016) [hereinafter Davis, What Might Replace the Modern Corporation?] (discussing "Nikefication"); Claire Moore Dickerson, Spinning Out of Control: The Virtual Organization and Conflicting Governance Vectors, 59 U. PITT. L. REV. 759, 762 (1998) (discussing firms acting as "hubs"); Kanter, supra note 249 , at 68 (referring to a "switchboard" firm).

253. John A. Byrne, The Virtual Corporation, Bus. WK., Feb. 8, 1993, at 98, 99; see Kanter, supra note 249, at 70-72, 74; Kevin Kelly et al., Learning from Japan, BUS. WK., Jan. 27, 1992, at 52, 52-53.

254. See Arruñada \& Vázquez, supra note 251, at 136; Kanter, supra note 249, at 68; Tully \& Welsh, supra note 249 , at 106 . "R\&D" refers to research and development.

255. See Davis, The Rise and Fall of Finance, supra note 251, at 33.

256. Id.

257. Id.

258. Id. at 34 (quoting Saul Hansell, Is This the Factory of the Future, N.Y. TIMES (July 26, 1998), http://www.nytimes.com/1998/07/26/business/is-this-the-factory-of-thefuture.html [https://perma.cc/LNT4-PSMB]). 
manufacturing has been outsourced to low-wage countries and in other industries to generic manufacturing plants. ${ }^{259}$

As a result of disaggregation, many major U.S. firms providing manufactured products have become "hollow" corporations, a term used to describe firms with no manufacturing operations. ${ }^{260}$ Fierce cost cutting has resulted in the gutting of managerial layers and the firing of workers from major firms. ${ }^{261}$ Manufacturing jobs that used to provide employees considerable security in employment and opportunities for advancement have declined. ${ }^{262}$ Manufacturing jobs have declined more dramatically since the late 1970s, and this trend has accelerated in the twenty-first century. ${ }^{263}$ Employees have increasingly turned to the service sector for employment. ${ }^{264}$ Many jobs themselves have changed as communication technologies have permitted automated monitoring of employees from remote locations. ${ }^{265}$

The disaggregation of firms through outsourcing has cost savings advantages at least in the short-term. The outsourcing of functions to specialty firms can create cost efficiencies because of the unique expertise, operating procedures, and culture associated with separate specialties. ${ }^{266}$ Firms may outsource their data processing services to data processing service firms, their security to outside security firms, secretarial work to temp worker firms, product assembly to component assembly firms, and so on. Moreover, the firms acquire access to critical resources often without ownership or hierarchical relationships. ${ }^{267}$ While these developments seem to fulfill the nexus of

259. See id. Competing firms often have overlapping supply chains. See James B. Rice, Jr. \& Richard M. Hoppe, Supply Chain vs. Supply Chain: The Hype \& the Reality, Supply Chain Mgmt. Rev. 46, 49 (2001). Some firms such as Uber Technologies, Inc. outsource tasks to individuals rather than to firms by providing smartphone applications. See Davis, What Might Replace the Modern Corporation?, supra note 252, at 511, 51213.

260. Anand \& Daft, supra note 249, at 334; Byrne, supra note 253, at 101; Jones, supra note 246, at 57; see Dickerson, supra note 252, at 277.

261. See Kanter, supra note 249 , at 76-78.

262. Jung, supra note 187, at 1336. Men entering the workforce in the 1980s and 90s were more likely to be employed in entry level jobs ten years later than in prior decades. Davis, The Rise and Fall of Finance, supra note 251, at 35.

263. Martin Neil Bailey \& Barry P. Bosworth, US Manufacturing: Understanding Its Past and Its Political Future, 28 J. ECON. PerspeCtives 3, 4 fig.1 (2014).

264. See infra note 436 . Uberization is a special case that provides intermittent workfor-pay tasks performed without security or benefits. Davis, What Might Replace the Modern Corporation?, supra note 252, at 512-13. 13.

265. See Davis, What Might Replace the Modern Corporation?, supra note 252, at 511-

266. See Kanter, supra note 249, at 70, 77.

267. Virgile Chassagnon, The Network-Firm as a Single Real Entity: Beyond the Aggregate of Distinct Legal Entities, 45 J. ECON. IssuES 113, 114-15, 119 (2011). This is also true for uberization that facilitates the use of previously unused physical and human 
contract conception of the firms, these relationships are not usually strictly market transactions - such as wheat or stock market transactions-but require monitoring, and some of them are often long term and quite open-ended. ${ }^{268}$ Some firms that outsource manufacturing to suppliers have taken a page from the Japanese playbook by decreasing their practice of selecting suppliers through competitive bidding and cultivating long-term relationships with them in order to encourage production innovations. ${ }^{269}$ Although resource dependencies among the parties often create disproportionate power relationships in many cases, ${ }^{270}$ these supplier relationships rely on mutual dependencies, reciprocity, and trust, often difficult for U.S. firms to achieve. ${ }^{271}$ Such relationships when nurtured can produce collaborative efficiencies and innovation. ${ }^{272}$ They can also produce disadvantages when not properly implemented. ${ }^{273}$ Such relationships may lead to the loss of in-house skills and innovative capacity. ${ }^{274}$ They may reduce control over supply and increase the risk of suppliers supplanting the outsourcing firm. ${ }^{275}$ Moreover, they involve substantial monitoring costs and, if not nurtured, may lead to a decline in investments by suppliers in production technologies. ${ }^{276}$

In summary, from an agency perspective the central issue of corporate governance is managerial self-interest. This has created a focus on maximizing shareholder value. The main structural development has been disaggregation

assets without the firm owning or purportedly employing them. Davis, What Might Replace the Modern Corporation?, supra note 252, at 502.

268. See Arruñada \& Vázquez, supra note 251, at 138-40 (discussing the importance of monitoring and different kinds of supplier relationships); Kanter, supra note 249, at 70; Robert D. Hof, Novellus: Thriving-With a Little Help from Its Friends, Bus. WK., Jan. 27, 1992, at 60; Kelly et al., supra note 253, at 54, 59.

269. See Hof, supra note 268, at 60; Kelly et al., supra note 253, at 54, 59.

270. Chassagnon, supra note 267, at 114-15, 119.

271. See id. at 119; Kanter, supra note 249, at 72; see also Jeffrey K. Liker \& Thomas Y. Choi, Building Deep Supplier Relationships, HARv. Bus. ReV., Dec. 2004, at 104 (criticizing U.S. auto manufacturers for their failure to create the kinds of successful relationships that Toyota and Honda create with their suppliers).

272. Arruñada \& Vázquez, supra note 251, at 138; see Kanter, supra note 249, at 73.

273. See Anand \& Daft, supra note 249, at 336; Kanter, supra note 249, at 72; Raymond E. Miles \& Charles C. Snow, Causes of Failure in Network Organizations, CAL. MGMT. REV., Summer 1992, at 53, 63, 64 tbl.2.

274. Anand \& Daft, supra note 249, at 336; see Arruñada \& Vázquez, supra note 251, at 137-39 (discussing the risk of infringement of intellectual property).

275. See Anand \& Daft, supra note 249, at 336; Arruñada \& Vázquez, supra note 251, at 137; Byrne, supra note 253, at 100.

276. See Anand \& Daft, supra note 249, at 336; Byrne, supra note 253, at 102 (noting monitoring needed when production is not up and running on time). 
through vertical disaggregation, outsourcing, and offshoring to achieve expected efficiencies. While developments in technology, globalization, and competition have contributed to disaggregation, it has been exaggerated by the adoption of the shareholder value maximization conception. ${ }^{277}$ In the next Part I discuss how firms have adopted agency theory prescriptions, such as substantial managerial compensation packages to align managerial compensation with stock prices, high leverage, large dividend payouts, and stock buybacks. I also discuss corporate cultures that have changed to focus on the short-term and a legislative agenda supportive of activism by short-term shareholders.

Before doing so, however, I point out unintended consequences of firms focusing on their core competencies and expanding horizontally in the face of lax antitrust enforcement. Since the late 1990s firms have grown mainly through horizontal mergers and acquisitions to maximize their core competencies, create synergies, increase their market share and market power, and cut costs through the elimination of redundancies. ${ }^{278}$ First, these acquisitions have resulted in a decrease in listed public firms from 1996 to 2012 as public firms have acquired other public firms, forming larger firms. ${ }^{279}$ Second, the rapid pace of merger and acquisition activity in the twenty-first century has enhanced further high industry concentration levels. ${ }^{280}$ There is evidence that a significant portion of mergers result in higher

277. See infra text accompanying notes 428, 429.

278. Davis et al., Political Agency, supra note 246, at 99; Kanter, supra note 249, at 66; Business in America: Too Much of a Good Thing, EconOMIst (Mar. 26, 2016), http://www.economist.com/news/briefing/21695385-profits-are-too-high-america-needsgiant-dose-competition-too-much-good-thing [hereinafter Business in America].

279. Craig Doidge et al., The U.S. Listing Gap, 123 J. FIN. ECON. 464, 464, 466 (2017). Delisting by public firms accounts for $46 \%$ of the general decrease in publicly listed firms from 1996-2012, largely because of mergers and acquisitions among publicly listed firms. Id. at 477-79. This study finds that the remaining 54\% decrease in listed firms is accounted for by the low rate of listings by new firms. Id. For other explanations of the listing gap, see Jeff Schwartz, The Twilight of Equity Liquidity, 34 CARDOZO L. REV. 531, 543-50 (2012).

280. See Gustavo Grullon et al., Are U.S. Industries Becoming More Concentrated? 1 (Aug. 31, 2017) (unpublished manuscript), https://papers.ssrn.com/sol3/papers.cfm? abstract_id=2612047 [https://perma.cc/3G5R-PA2M]; Business in America, supra note 278 (noting that two-thirds of industry sectors became more concentrated between 19972012 , business lobbying doubled over this period, and since 2008, U.S. firms have engaged in mergers worth \$10 trillion); Neil Howe, Why Markets Keep Concentrating-And How That Hurts Our Economy, FoRBES (Dec. 30, 2015, 11:16 AM), http://www.forbes.com/sites/ neilhowe/2015/12/30/why-markets-keep-concentrating-and-how-that-hurts-our-economy/2/ \#42beeda777a6 [https://perma.cc/5TDF-TK4X]. Lax antitrust enforcement has contributed to this development. See David Dayen, Bring Back Antitrust, AM. Рrospect (Nov. 9, 2015), http://prospect.org/article/bring-back-antitrust-0 [https://perma.cc/BKS5-84M6]. 
prices for consumers. ${ }^{281}$ Overall, in a wide range of U.S. business sectors firms earn abnormal profits, shareholders experience abnormal stock returns, and these profits do not benefit consumers in the form of lower prices. ${ }^{282}$ Large firms with considerable market power, when combined with their treatment as persons with constitutional rights, pose considerable societal challenges requiring rethinking of antitrust regulations and conceptions of good corporate governance. ${ }^{283}$

In a 2007 retrospective of the 1980 article, Managing Our Way to Economic Decline, Professor Hayes viewed his earlier article, with coauthor Professor Abernathy, as a call for U.S. managers to get back to basicsto improve quality, responsiveness and technological innovation. ${ }^{284}$ But in this 2007 retrospective he saw U.S. firms, since the late 1990s, as having a "get-rich-quick, bubble mentality," resulting in managers turning away from the "pursuit of operating excellence." 285

281. John E, Kwoka, Jr., Does Merger Control Work? A Retrospective on U.S. Enforcement Actions and Merger Outcomes, 78 ANTITRUST L.J. 619, 621, 634 (2013); Dayen, supra note 280.

282. See Kwoka, Jr., supra note 281 , at 621,634 . A recent study found abnormal profits in industries with decreasing numbers of competitors. Grullon et al., supra note 280, at 2. It also finds abnormal stock returns for shareholders. Id. at 3. Although the source of these abnormal profits is unclear, the profits suggest an increase in market power of large firms. Id. at 2, 4. The study found that the decline in the number of publiclylisted firms has not been offset by competition from private and foreign firms. Id.; see also Business in America, supra note 278 (providing evidence on the increased domination of industries by the top four firms from 1997 to 2012 and abnormal profits); Dayen, note 280 (explaining that economic consolidation harms consumers, workers and innovators). Horizontal mergers among public firms are the major cause of the delisting of public firms on national stock exchanges. See Ashley Lutz, These 6 Corporations Control $90 \%$ of the Media in America, Bus. INSIDER (June 14, 2012, 9:49 AM), http://www.businessinsider.com/ these-6-corporations-control-90-of-the-media-in-america-2012-6 [https://perma.cc/G5XDXPZM] (noting that 6 firms, consolidated from 50 firms in 1983, control $90 \%$ of "what we read, watch, or listen to"); Asher Schechter, Economists: "Totality of Evidence" Underscores Concentration Problem in the U.S., Pro-MARKeT (Mar. 31, 2017), https:// promarket.org/economists-totality-evidence-underscores-concentration-problem-u-s/ [https://perma.cc/87P5-DAYJ] (discussing views at an academic conference on concentration evidence, implications of concentration, and advisability of more aggressive antitrust enforcement).

283. See, e.g., Citizens United v. Fed. Election Comm'n, 558 U.S. 310 (2010) (finding that corporations' political spending was protected by the First Amendment).

284. See Robert H. Hayes, “Managing Our Way. ..” A Retrospective, in Robert H. Hayes \& William J. Abernathy, Managing Our Way to Economic Decline, HaRV. Bus. REV., July-Aug 2007, at 141 (included in reprint of Hayes \& Abernathy, supra note 216, at 67$)$.

285. Id. 


\section{CONSEQUENCES OF THE SHAREHOLDER VALUE MAXIMIZATION CONCEPTION AND THE EMERGENCE OF THE SUSTAINABILITY CONCEPTION}

I provide below in Part IV.A a comprehensive examination of the major consequences of the shareholder value maximization conception of "good" corporate governance that sets the stage for a new conception. In the course of this analysis, I highlight the significance of the corporate scandals of the early 2000s and the financial crisis of 2007-2009. In Part IV.B I offer the sustainability conception as an emerging conception of corporate governance and propose reforms that would further support its evolution.

\section{A. The Shareholder Value Maximization Conception of "Good" Corporate Governance}

\section{Firm Purpose}

As previously discussed, the shareholder value maximization conception began to influence business thinking, structures, and strategies in the late 1970s and is currently the dominant conception, at least in scholarly debates. Pronouncements of corporate purpose by the Business Roundtable, a prestigious association of CEOs of leading U.S. firms, show how the shareholder value maximization conception changed corporate purpose and the thinking of managers. ${ }^{286}$ In 1981 the Business Roundtable stated "[c]orporations have a responsibility, first of all, to make available to the public quality goods and services at a fair prices, thereby earning a profit that attracts investment to continue and enhance the enterprise, provide jobs, and build the economy." 287 In contrast, in 1997 the Business Roundtable stated that " $[t]$ he principal objective of a business enterprise is to generate economic returns to its owners. If the CEO and the directors are not focused on shareholder value, it may be less likely the corporation will realize that value."288 Therefore, rather than managers concentrating on providing quality goods at fair prices, a reasonable return to shareholders, employment, and building the economy, the managers' purpose became to maximize shareholder returns. Many progressive corporate law scholars were critical of this approach but were unable to prevent it from becoming generally accepted. ${ }^{289}$

286. See Gomory \& Sylla, supra note 115 , at 107, 109-10.

287. Id. at 107 (quoting Bus. ROUNDTABLE, STATEMENT ON CORPORATE RESPONSIBILITY 12 (Oct. 1981)).

288. Id. at 109-10 (quoting Bus. RoundTABLE, STATEMENT ON CORPORATE GOVERNANCE 1-2 (Sept. 1997)).

289. These scholars included Douglas M. Branson, William W. Bratton, Lynne L. Dallas, Claire Moore Dickerson, Kent Greenfield, Daniel J.H. Greenwood, Lyman P.Q. Johnson, David Millon, Lawrence E. Mitchell, Marleen A. O'Connor, Eric W. Orts, Terry O’Neill, 


\section{Meeting or Beating Quarterly Earnings Expectations}

The shareholder value maximization conception contributed to negative unintended consequences, particularly in encouraging unethical behavior. Executive officers and corporate boards came to believe that it was of utmost importance that their firms meet the quarterly earnings expectations of security analysts who influenced the stock prices of their firms. ${ }^{290}$ They sought to avoid adverse short-term effects on their businesses and on them personally, which would occur if they did not meet these expectations. ${ }^{291}$ From a business perspective, satisfying stock market expectations signaled to customers, suppliers, and shareholders that the firm was successful and assisted in the firms' ability to succeed, including obtaining financing on favorable terms. ${ }^{292}$ Unsuccessful managers faced the likelihood of being replaced or having their firms taken over. ${ }^{293}$ Thus, managers sought to maximize shareholder value by increasing their firm's stock price. The focus on stock price became paramount. Enron even had a stock ticker tape in its Houston headquarters' elevator. ${ }^{294}$

Because of the likely adverse consequences to their firms and themselves, many managers did whatever it took to meet the numbers. ${ }^{295}$ Firms engaged in numerous transactions, such as mergers and acquisitions, stock repurchases, and divestitures, to impress the stock market. ${ }^{296}$ They also engaged in what is called "earnings management." 297 They cut discretionary spending, such as R\&D expenses, and downsized by firing employees in

Faith Stevelman, Kellye Testy, Lynn Stout, Cheryl L. Wade, and Cynthia Williams. See generally Progressive Corporate Law: New Perspectives on Law, Culture, and Society (Lawrence E. Mitchell ed., 1995) (including articles from some of these scholars).

290. Dobbin \& Jung, supra note 155, at 39; David Millon, Shareholder Social Responsibility, 36 SEATTLE U. L. REV. 911, 916-17 (2013) [hereinafter Millon, Shareholder Social Responsibility].

291. See Lynne L. Dallas, Short-Termism, the Financial Crisis, and Corporate Governance, 37 J. CORP. L. 265, 271-72 (2012) [hereinafter Dallas, Short-Termism].

292. See id. at 271; Millon, Shareholder Social Responsibility, supra note 290, at 915.

293. Dallas, Short-Termism, supra note 291, at 272.

294. Sverre Rørvik Nilsen, The Enron Code of Ethics Handbook from July 2000 Is a Fascinating Read, CFA INST. BLOG (Oct. 14, 2013), https://blogs.cfainstitute.org/investor/2013/ 10/14/the-enron-code-of-ethics-handbook-from-july-2000-is-a-fascinating-read/ [https:// perma.cc/QQB2-BWYQ].

295. See Millon, Shareholder Social Responsibility, supra note 290, at 918-19.

296. See id. at 915 .

297. Dallas, Short-Termism, supra note 291, at 278-81; Dallas, The New Managerialism, supra note 237 , at 1380 . 
order to meet the numbers. ${ }^{298}$ They also manipulated their financial results and used off-sheet balance sheet transactions to obscure their true liabilities. ${ }^{299}$ One study found that myopic behavior by firms seeking to meet quarterly earnings expectations had deleterious long-term effects on firm performance. ${ }^{300}$ This study suggests, contrary to agency theory, that managers "caring too much" about stock prices harms shareholders in the long run. ${ }^{301}$

Exemplifying these concerns was the famous "Numbers Game" Speech given in 1998 by Arthur Levitt, then Chairman of the Securities and Exchange Commission (SEC). ${ }^{302}$ In this speech Levitt criticized the sophisticated methods managers were using to create false perceptions of their firms' earnings that were contained in financial statements provided to their shareholders. ${ }^{303}$ Other SEC spokespersons lamented the need for a "cultural change" due to the willingness of firms to make misstatements in their financial statements. ${ }^{304}$ A 1998 poll of CFOs found that $45 \%$ of CFOs reported that their superiors had asked them to misstate their firm's financial numbers and $38 \%$ of them complied. ${ }^{305}$ Moreover, $78 \%$ of CFOs in the study reported they had been asked to utilize accounting rules to create a more favorable impression of their firm's financial information and 50\% of them did so. ${ }^{306}$ A more recent survey found that a "majority of CFOs admit to sacrificing long-term [firm] economic value to hit a target or to smooth short-term earnings." 307

298. See Dallas, Short-Termism, supra note 291, at 279 (noting that this approach is referred to as "real earnings management").

299. Id. at 278 (noting that this approach is referred to as "accounting earnings management").

300. See Natalie Mizik, The Theory and Practice of Myopic Management, $47 \mathrm{~J}$. MARKETING RES. 594, 595-96 (2010). Contrary to the predictions of the efficient market hypothesis, firms benefit from myopic behavior in the short term because stock prices do not reflect such behavior at the time it occurs. See Dallas, Short-Termism, supra note 291, at 599 .

301. Dallas, Short-Termism, supra note 291, at 273.

302. Arthur Levitt, former SEC Chairman, The "Numbers Game" at the New York University Center for Law and Business (Sept. 28, 1998), https://www.sec.gov/news/speech/ speecharchive/1998/spch220.txt [https://perma.cc/TZ34-Q6UL].

303. Id.

304. Stephen Barr, Misreporting Accounting Results, CFO MAG. (Dec. 1, 1998), http:// ww2.cfo.com/accounting-tax/1998/12/misreporting-results/ [https://perma.cc/U84Y-7EJD].

305. Id. (noting that a Business Week survey produced similar results).

306. Id.

307. John R. Graham et al., The Economic Implications of Corporate Financial Reporting, 40 J. ACCT. \& ECON. 3, 67 (2005); see also Ilia D. Dichev et al., Earnings Quality: Evidence from the Field, 56 J. ACCT. \& ECON 1, 1 (2013) (finding in survey of CFOs of public companies that "in any given period, about $20 \%$ of firms manage earnings to misrepresent economic performance, and for such firms $10 \%$ of [earnings per share] is typically managed"). 


\section{Executive Compensation}

As previously noted, managers have both business and personal reasons to enhance their firm's stock prices. Agency theory focuses on personal reasons to encourage them to do so. ${ }^{308}$ As previously discussed, this theory essentially views managers as primarily motivated by their self-interest. ${ }^{309}$ Therefore, it promotes managerial compensation that aligned their compensation with the interests of the shareholders. ${ }^{310}$ Compensation arrangements that apparently rewarded managers for growth under managerialism - with the profit motive as a constraint - were viewed as inferior to the shareholder value maximization conception that favored pay-for-performance arrangements based on stock price improvements. ${ }^{311}$

Stock options have become a favored form of compensation. ${ }^{312}$ While stock options had been an important part of long-term equity compensation since the 1950s, firms' use of stock options increased dramatically in the 1990s and provided substantial compensation to executives in the rising stock market of the $1990 \mathrm{~s}^{313} \mathrm{~S} \& \mathrm{P}$ data shows that almost $80 \%$ of median CEO compensation from 1992 to 2000 was due to the growth in long-term equity incentives that consisted mainly of stock options. ${ }^{314}$ Stock-based compensation was supported by the IRS's exemption of performance-based pay from the $\$ 1$ million deductibility limit on executive compensation, added to the tax code in $1993 .^{315}$ In addition, accounting rules at the time favored stock options because firms were not required to recognize the stock

308. See supra text accompanying note 155.

309. See supra text accompanying notes 153,155 . The impact of agency theory in the education of students in U.S. business schools was to change the objectives of managers from that of stewards or industrial statesmen to individuals seeking to maximize returns on discreet transactions. See KHURANA, supra note 148, at 323, 325.

310. See supra note 155.

311. See Batt \& Appelbaum, supra note 111, at 13-14 (discussing agency theory as encouraging pay-for-performance compensation arrangements and stock options); supra text accompanying notes 151,155 .

312. See Millon, Shareholder Social Responsibility, supra note 290, at 916.

313. JoHn C. COFFEe, GATEKEEPERS: The Professions AND CoRPORATE GOVERNANCE 62 (2006).

314. CONFERENCE BD., COMMISSION ON PuBlic TRUST AND PRIVATE ENTERPRISE: FindingS AND RECOMMENDATIONS 6 n.3 (2003) (reporting that options rose as a proportion of median CEO compensation from $27 \%$ in 1992 to $60 \%$ in 2000$)$.

315. 26 U.S.C. $\S 162(\mathrm{~m})(2012)$. 
options as expenses on their financial statements when they were granted. ${ }^{316}$ Firm earnings were inflated on financial statements for this reason and thus misled shareholders as to the true value of their shares. ${ }^{317}$ Stock options also gave managers the incentive to manipulate financial information due to legal rules that exempted options from short swing profit rules when exercised. ${ }^{318}$ Also, structurally, stock options did not align the interests of managers and shareholders, as ultimately acknowledged by agency theorists. ${ }^{319}$ Because managers who held options won when the firm did well but they did not lose when the firm did poorly, they were motivated to make more risky decisions than preferred by diversified shareholders. ${ }^{320}$

\section{The Cognitive and Motivational Context for Managerial Decision Making}

The shareholder value maximization conception has contributed to the cognitive and motivational context for managerial decision making in encouraging unethical behavior. While managers had always cared about the stock price of their firms, they are now primarily evaluated on the basis of their firm's stock price. ${ }^{321}$ It is well known that unethical behavior increases when compensation is based on outcome rather than the process - that is, the behavior undertaken in reaching an outcome. ${ }^{322}$ Firms are expected to

316. Nicholas G. Apostolou \& D. Larry Crumbley, Accounting for Stock Options: Update on the Continuing Conflict, CPA J. (2005), http://archives.cpajournal.com/2005/ 805/essentials/p30.htm [https://perma.cc/4SDG-P5XF].

317. Dallas, The New Managerialism, supra note 237, at 1379-80.

318. The SEC changed it rules in 1991 to exempt trades of securities underlying options from Section 16(b) of the Securities Exchange Act of 1934 if they were made six months after the options were granted, rather than six months after they were exercised. Ownership Reports and Trading by Officers, Directors and Principal Security Holders, Exchange Act Release No. 34-28869, 56 Fed. Reg. 7242, 7242, 7250, 7256, 7271 (Feb. 21, 1991); see also Dobbin \& Jung, supra note 155, at 40 ("Options created an incentive for executives to 'manage' earnings statements, inflating earnings when they were depressed and deflating when they were above expectations ...."').

319. See Claudia H. Deutsch, An Early Advocate of Stock Options Debunks Himself, N.Y. Times (Apr. 3, 2005), http://www.nytimes.com/2005/04/03/business/yourmoney/anearly-advocate-of-stock-options-debunks-himself.html?_r=0.

320. An executive who exercises an option when the stock price goes above the option's exercise price obtains a benefit measured by the difference between the stock price and the option's exercise price. If the stock price falls below the option's exercise price, the executive will not exercise the option and thus, he will not suffer a loss. In contrast, the shareholder who owns shares will benefit when the stock price goes up and will suffer a loss when the stock price goes down. See Dallas, The New Managerialism, supra note 237, at 1379; Dobbin \& Jung, supra note 155 , at 37-38.

321. See supra Section IV.A.3 \& note 293; see also infra note 386.

322. See Lynne L. Dallas, A Preliminary Inquiry into the Responsibility of Corporations and Their Officers and Directors for Corporate Climate: The Psychology of Enron's 
take actions necessary to boost their stock price when it appears that they would not meet quarterly expectations. ${ }^{323}$ There are a number of actions in the managers' playbook to accomplish this purpose but they are often short-term oriented and would not be undertaken in other circumstances. ${ }^{324}$

Managers are also encouraged to look outward to the shareholders as their constituency. Their high compensation is justified by comparing it with often high stock prices. ${ }^{325}$ Consequently, internal disparities in compensation have increased dramatically. From 1978 to 2012, CEO compensation increased $875 \%$, compared to $5.4 \%$ for the typical worker. ${ }^{326}$ The CEO-employee pay ratio grew from $29.1 \%$ to $272.9 \%$ during this same period. ${ }^{327}$ The high compensation of CEOs and the disparities in compensation have a number of consequences.

First, they have an impact on employee perceptions of the set of values considered as legitimate and moral within their firm. ${ }^{328}$ They send a message that the primary purpose of the firm is to serve individual selfinterest. ${ }^{329}$ This is an egoism culture that is associated with unethical behavior. ${ }^{330}$ It encourages actions that serve the self-interest of individual employees but do not serve the long-term interest of firms. Moreover, even unethical cultures perpetuate themselves by determining the kinds of individuals that the firm attracts, selects, retains, and promotes. ${ }^{331}$

Second, high compensation and large disparities in compensation activates a manager's economic self-concept, making economics much more salient to

Demise, 35 RutGers L.J. 1, 34-35 (2003) [hereinafter Dallas, The Psychology of Enron's Demise].

323. See supra Section IV.A.2.

324. E.g., Levitt, supra note 302 (discussing the taking of "“big bath' restructuring charges, creative acquisition accounting, 'cookie jar reserves,' 'immaterial' misapplications of accounting principles, and the premature recognition of reserves").

325. See Dallas, The New Managerialism, supra note 237, at 1365.

326. Natalie Sabadish \& Lawrence Mishel, CEO Pay in 2012 Was Extraordinarily High Relative to Typical Workers and Other High Earners, ECON. POL'Y INST. (June 26, 2013), http://www.epi.org/publication/ceo-pay-2012-extraordinarily-high/ [https://perma.cc/ 26QE-SN9T].

327. Id.

328. See Dallas, The Psychology of Enron's Demise, supra note 322, at 36; Sreedhari D. Desai et al., When Executives Rake In Millions: The Callous Treatment of Lower Level Employees 6-7 (July 21, 2011) (unpublished manuscript) (on file with author).

329. Dallas, The Psychology of Enron's Demise, supra note 322, at 36.

330. See id. at 28-32, 36.

331. Id. at 29 (quoting Benjamin Schneider, Work Climates: An Interactionist Perspective, in Environmental Psychology: Directors and Perspectives 109, 119 (Nickolaus R. Feimer \& E. Scott Geller eds., 1983)). 
him. ${ }^{332}$ This increases the likelihood that a manager will view employees as merely short-term means to an end. ${ }^{333}$ One study found that downsizing of a firm's workforce was more frequent when a significant portion of a CEO's compensation consisted of stock options that encourage a focus on stock prices. ${ }^{334}$ High compensation fueled by stock options and large disparities in compensation by symbolizing managerial status and power create greater psychological distance between managers and lower-level employees and less sensitivity to social disapproval supporting unethical behavior. ${ }^{335}$ One study found an association between high CEO compensation and the callous treatment of lower-level employees. ${ }^{336}$ The definition of callous treatment in this study included significant workforce reductions, poor union relations, substantial penalties or controversies regarding employee health and safety standards, underfunded or inadequate retirement plans, and other employee relation controversies. ${ }^{337}$

Third, high compensation and large disparities in compensation increases the likelihood of overconfidence on the part of CEOs. ${ }^{338}$ Overconfidence results in inappropriate assessments of risk. Moreover, it can lead to less managerial accountability when disparities in compensation lead employees to curry favor with the CEO, or other higher level managers, in hopes of increasing their compensation. ${ }^{339}$ Managers receive less critical feedback from employees and therefore become less accountable in this politicized

332. Id. at 36-37; see Black \& Carbone, supra note 111, at 394-95 (noting that rather than serving as stewards of their firms and being concerned with its wellbeing, the measure of success to CEOs became their bank accounts); Desai et al., supra note 328, at 6-7.

333. Desai et al., supra note 328 , at 9.

334. Jung, supra note 187 , at 1360.

335. Desai et al., supra note 328, at 7-8. Increased power of the CEO is associated with more political behavior at firms, including "behind-the-scenes coalition formation, office lobbying, cooptative attempts, withholding information, and the controlling of agendas." Lynne L. Dallas, The Multiple Roles of Corporate Boards of Directors, 40 SAN DIEGO L. REV. 781, 817 (2003) (citing Kathleen M Eisenhardt \& L.J. Bourgeois III, Politics of Strategic Decision Making in High-Velocity Environments: Toward a Midrange Theory, 31 ACAD. MgMT. J. 737, 749-53, 763-65 (1988)).

336. Desai et al., supra note 328 , at 3-4.

337. Id. at 11-12.

338. Dallas, The Psychology of Enron's Demise, supra note 322, at 37; see Mathew L.A. Hayward \& Donald C. Hambrick, Explaining the Premiums Paid for Large Acquisitions: Evidence of CEO Hubris, 42 ADMIN. SCI. Q. 103, 114 (1997) (using the difference in pay between the CEO and the second highest paid executive officer as a measurement of hubris); Troy A. Paredes, Too Much Pay, Too Much Deference: Behavioral Corporate Finance, CEOs and Corporate Governance, 32 FLA. ST. U. L. REV. 673, 717-19 (2005) (noting that large compensation packages and lavish perks give CEOs a sense of self-importance and contribute to their status and the deference given to them by others in the firm).

339. Dallas, The Psychology of Enron's Demise, supra note 322, at 36-37. See also supra note 335 . 
environment, which in turn feeds their overconfidence. ${ }^{340}$ This dynamic was at work at Enron prior to its downfall. ${ }^{341}$

Fourth, egoism cultures experience difficulties creating covenantal relationships as distinct from transactional relationships within firms. ${ }^{342}$ Transactional relationships are instrumental relationships, often shortterm, in which parties engage in the economic exchange of skills and other resources. ${ }^{343}$ Covenantal relationships have a deeper connection, involving mutual commitment, shared value, and produce citizenship behaviors that promote the long-term interests of firms. ${ }^{344}$

Finally, the strategies encouraged by the changing conceptions-from those of managerialism to shareholder value maximization-influenced managers' strategies and their perceptions of firm employees. ${ }^{345}$ Scholars have explained that under managerial capitalism the business model was to seek "returns on investments derive[d] from the value created by productive business enterprises," whereas under finance capitalism "companies are viewed as assets to be bought and sold and as vehicles for maximizing profits through financial strategies." ${ }^{.346}$ Under finance capitalism, workers are human assets and viewed the same way as any other asset.

In sum, a reason why the shareholder maximization conception is problematic is its contribution to the cognitive and motivational context it creates for firm decision making. As practically implemented, it results in firms that are prone to unethical and short-term behaviors. ${ }^{347}$

340. Id. at 37 .

341. See generally id. at 35-55 (discussing the impact of employee compensation disparities and overconfidence at Enron). Jeffrey Skilling, Enron CEO, reportedly developed during his tenure a "God syndrome." Id. at 48-49 (citing Evan Thomas et al., Every Man for Himself, NEWSWEEK, Feb. 18, 2002, at 27-28).

342. Tim Barnett \& Elizabeth Schubert, Perceptions of the Ethical Work Climate and Covenantal Relationships, 36 J. BUS. ETHICs 279, 288 (2002).

343. Id. at 280 .

344. Id. at 288 (citing Jill W. Graham \& Dennis W. Organ, Commitment and the Covenantal Organization, 5 J. MANAGERIAL Issues 483, 485 (1993); Linn Van Dyne et al., Organizational Citizenship Behavior: Construct Redefinition, Measurement, and Validation, 37 ACAD. MgMt. J. 765, 768 (1994)).

345. See supra Parts II-IV.

346. Paul Kennedy, VAmpire Capitalism: Fractured Societies and Alternative FUTURES 79 (2017).

347. See KHURANA, supra note 148, at 324-26 (discussing changes in the education of managers at business schools away from a notion of professionalism under managerialism to the legitimization of self-interested behaviors). 


\section{Short-Term Equity Traders}

An additional problem with the shareholder value maximization conception is that while putting the shareholders first, it did not properly differentiate among long-term and short-term shareholders and the increasing influence of short-term shareholders. ${ }^{348}$ There is evidence that firms with a predominance of short-term shareholders are more likely to engage in unethical and short-term behaviors. The predominance of short-term shareholders has been associated with the overvaluation of near-term earnings ${ }^{349}$ and earnings management. ${ }^{350}$ For example, it has been associated with abnormal accruals and the cutting of R\&D expenses to meet quarterly earnings expectations. ${ }^{351}$ It has also been associated with financial misstatements and weak internal controls ${ }^{352}$ as well as value-reducing acquisitions. ${ }^{353}$ These associations have not been found for firms with a predominance of

348. Institutional investors have been categorized as long-term and short-term shareholders. Dallas, Short-Termism, supra note 291, at 303-04. Long-term shareholders include two groups of investors: dedicated institutional investors - which invest in few firms and have a high percentage of shares held for two years, often over $75 \%$ - and quasi-indexer institutions which have diversified portfolios but trade infrequently. Id. at 304. These are both stable shareholders. Id. Short-term shareholders - often referred to as transient institutional investorshave highly-diversified portfolios with often more than $70 \%$ of their stock turned over within a quarter. Id. at 303-04.

349. Id. at 304 (citing Brian J. Bushee, Do Institutional Investors Prefer Near-Term Earnings Over Long-Run Values?, 18 CONTEMP. ACCT. RES. 207, 213 (2001)).

350. Id. (citing Brian Bushee, The Influence of Institutional Investors on Myopic R\&D Investment Behavior, 73 ACCT. REV. 305, 307 (1998); Ping Sheng Koh, Institutional Investor Type, Earnings Management and Benchmark Beaters, 26 J. AcCT \& PUB. POL'Y 267, 269-70, 294-95 (2007); Dawn A. Matsumoto, Management's Incentives To Avoid Negative Earnings Surprises, 77 ACCT. REV. 483, 487, 507, 511 (2002)). One study finds that although short-termism may be fueled by pressure from transient shareholders, it is equally true that transient shareholders are attracted to companies that have executives with short-term orientations and short-term cultures. Francois Brochet et al., Short-Termism: Don't Blame Investors, HARV. BUS. REV., June 2012, at 28, 28. Evidence is mixed on whether short-term shareholders, variously defined, contribute to market efficiency. See Lynne L. Dallas \& Jordan M. Barry, Long-Term Shareholders and Time-Phased Voting, 40 DEL. J. CORP. L. 541, 561 n.68 (2016).

351. Dallas, Short-Termism, supra note 291, at 304.

352. Id. at 305 (citing Natasha Burns et al., Institutional Ownership and Monitoring: Evidence from Financial Misreporting, 16 J. CORP. FIN. 443, 450, 453-54 (2010); Alex P. Tang \& Li Xu, Institutional Ownership and Internal Control Material Weakness, 49 Q.J. FIN. \& ACCT. 93, 95 (2010)).

353. Id. at 305 (finding that the predominance of short-term shareholders in firms has been correlated with an increased likelihood of takeovers but also overbidding transactions and value-reducing acquisitions (citing José-Miguel Gaspar et al., Shareholder Investment Horizons and the Market for Corporate Control, 76 J. FIN. ECON. 135, 138 (2005))). High stock turnover in firms has also been associated with poorer firm investment decisions. Dallas, Short-termism, supra note 291, at 306 (citing Christopher Polk \& Paola Sapienza, The Stock Market and Corporate Investment: A Test of Catering Theory, 22 REV. FIN. STUD. 187, 188, 205 (2009)). 
long-term investors. ${ }^{354}$ Therefore, the shareholder maximization conception falters in the context of financial markets that have increasingly come to be dominated by the trading of short-term shareholders.

\section{Financial Scandals of the Early 2000s}

The negative consequences of the shareholder value maximization conception became very public with the corporate scandals in the early 2000s at Enron, WorldCom, Tyco, Adelphi and other firms. ${ }^{355}$ Enron and the other firms were large multi-layered subsidiary firms utilizing their vast networks to obscure their actual financial conditions. ${ }^{356}$ In fact, Enron was once a very highly regarded U.S. firm. Fortune Magazine declared it to be the most innovative firm in the United States for six consecutive years, but it was in reality a house of cards. ${ }^{357}$ Its culture was fixated on financial numbers and meeting or beating security analysts' expectations. ${ }^{358}$ The egoism culture within Enron led to unethical and short-term behavior on the part of its managers and resulted in the ultimate demise of the firm. ${ }^{359}$ Outrage over these high-profile scandals that destroyed large firms caused Congress to pass the Sarbanes-Oxley Act of 2002 to address pervasive accounting irregularities and fraudulent practices in U.S. firms. ${ }^{360}$ Many firms therefore began to restate their previously filed financial statements.

354. See Dallas, Short-Termism, supra note 291, at 305 (citing Burns et al., supra note 352, at 444).

355. See generally Franklin R. Edwards, U.S. Corporate Governance: What Went Wrong and Can It Be Fixed (2003) (unpublished manuscript), https:/www0.gsb.columbia.edu/mygsb/ faculty/research/pubfiles/1661/U.S.\%20Corporate\%20Governance\%2010-05.pdf [https:// perma.cc/NG56-6R2F] (discussing the failure of corporate governance mechanism to protect shareholders from the financial scandals of the early 2000 s that involved massive financial misreporting and managerial self dealing). A discussion of the savings and loan crisis and the dot-com bubble is beyond the scope of this Article.

356. See John Boies \& Harland Prechel, Capital Dependence, Business Political Behavior, and Change to the Multilayered Subsidiary Form, 49 Soc. ProBs. 301, 309-10 (2002).

357. Howard Kurtz, The Enron Story That Waited To Be Told, WASH. Post (Jan. 18, 2002), http://www.washingtonpost.com/wp-dyn/articles/A64769-2002Jan17.html [https:// perma.cc/89HN-G4ZL].

358. See Dallas, The Psychology of Enron's Demise, supra note 322, at 45, 49-50. Andrew Fastow, the CFO of Enron, is a notorious example of a CFO who engaged in the manipulation of financial numbers to enable his firm to meet earnings expectations. See Dobbin \& Zorn, supra note 151, at 194 (citing Daniel Altman, The Taming of the Finance Officers, N.Y. TIMES (Apr. 14, 2002), http://www.nytimes.com/2002/04/14/business/thetaming-of-the-finance-officers.html).

359. See Dallas, The Psychology of Enron's Demise, supra note 322, at 45-51.

360. Sarbanes-Oxley Act of 2002, Pub. L. No. 107-204, 116 Stat. 745. 
For example, 83 NYSE listed firms restated their financial statements in 1997, compared to 220 in the first six months of 2002. ${ }^{361}$

Some scholars view the adoption of the Sarbanes-Oxley Act as signaling the beginning of the end of an era of the imperial, charismatic CEOs during the 1990 s and early $2000 \mathrm{~s}^{362}$ to be replaced by the "embattled CEOs" of the twenty-first century who are more subject to regulation and oversight. ${ }^{363}$ However, the embattled CEOs face even greater short-term pressures with short-term shareholders benefiting from changes that have enhanced shareholder power. ${ }^{364}$ Moreover, adherence to the shareholder value maximization conception has not changed nor has pressure from short-term equity traders. While most scholars would favor enhanced monitoring of firms by shareholders as a counterweight to managerial power, underlying this view was the implicit assumption that long-term shareholders-not short-term shareholderswould do the monitoring. ${ }^{365}$

361. Harland Prechel \& Theresa Morris, The Effects of Organizational and Political Embeddedness on Financial Malfeasance in the Largest U.S. Corporations: Dependence, Incentives, and Opportunities, 75 AM. Soc. REv. 331, 346 (2010) (noting additionally that "between 2002 and $200516[\%]$ of the companies listed on the three major stock exchanges announced restatements" (citing Robert Tillman \& Michael Indergaard, Control Overrides in Financial Statement Fraud: A Report to the Institute for Fraud Prevention 1-2 (Jan. 16, 2007) (unpublished manuscript), https://www.researchgate.net/publication/241868976_ Control_Overrides_in_Financial_Statement_Fraud)).

362. See Cheffins, Corporate Governance, supra note 16, at 738 (quoting Joshua Chaffin, Exit the Emperor-Bosses, Leaving a Legacy of Prudence, FIN. TIMES (London), Mar. 19, 2005, at 11). See also supra text accompanying note 235 .

363. See Cheffins, Corporate Governance, supra note 16, at 742; Coffee, Jr. \& Palia, supra note 147, at 559-61 (noting that legal changes enabled shareholders to play a more active role in corporate governance); Kahan \& Rock, supra note 147, at 998-1005, 100722, 1030-32, 1034-36 (2010) (discussing the loss of CEO power to boards of directors, evidenced by increased CEO turnover rates, and the loss of CEO power to shareholders as a result of regulatory and other changes that support shareholder activism). This period represents an evolution of shareholder activism with shareholders playing a more handson role in corporate governance. Cheffins, Corporate Governance, supra note 16, at 73334 (stating that in contrast, "the 1990s institutional investors generally shied away from taking on a substantial hands-on corporate governance role" in favor of pressuring boards of directors to exercise managerial oversight and adopt pay-for-performance arrangements for managers).

364. See Kahan \& Rock, supra note 147, at 1007-36 (2010) (detailing changes in governance rules, regulatory changes, board composition, and executive compensation).

365. Note that the SEC has clearly stated that its primary focus as well is on the interests of long-term investors rather than professional traders. Concept Release on Equity Market Structure, Exchange Act Release No. 34-61358, 75 Fed. Reg. 3594, 3603 (proposed Jan. 21, 2010). 


\section{Hedge Fund Activism}

Firm monitoring by hedge funds - who are short-term shareholdershas increasingly dominated the corporate landscape. ${ }^{366}$ Facilitated by the shareholder value maximization conception, activist hedge funds seek to influence firm decisions by threatening to engage, or engaging, in proxy contests if their agendas are not followed. ${ }^{367}$ CEOs are indeed embattled by this activism. Twenty percent of S\&P 500 firms were the targets of hedge fund activism between 2009 and $2014 .{ }^{368}$ There were 1115 such campaigns from 2010 to $2014{ }^{369}$ Hedge funds invest in few firms but have holding periods of a year or less from their time of filing their Schedule 13Ds. ${ }^{370}$ Managers of hedge funds are compensated based on $2 \%$ of the assets under their management and $20 \%$ of the return on their fund's investments. ${ }^{371}$ They and their clients are willing to accept high risk for the potential of high returns. ${ }^{372}$ They target specific firms to achieve their goals. ${ }^{373}$ Their activism seeks firm changes that would cause a sharp rise in stock prices within a short period of time. In essence, hedge funds seek short-term arbitrage opportunities through their activism. ${ }^{374}$ They usually focus on liquidity events, such as large one-time dividend payouts, stock repurchases, or the sale of some of the firm's assets or the firm in its entirety. ${ }^{375}$

366. See Coffee, Jr. \& Palia, supra note 147, at 548.

367. See id. at 553-56.

368. Cheffins, Corporate Governance, supra note 16, at 742.

369. Coffee, Jr. \& Palia, supra note 147, at 554 (citing Liz Hoffman \& David Benoit, Activist Funds Dust Off Greenmail Playbook, WALL ST. J. (June 11, 2014), at C1, https:// www.wsj.com/articles/activist-funds-dust-off-greenmail-playbook-1402527339 [https:// perma.cc/Q7JS-CWQG]).

370. Id. at 567.

371. Id. at 573

372. Id.

373. See id.

374. See Dallas, Short-Termism, supra note 291, at 307.

375. Coffee, Jr. \& Palia, supra note 147, at 572; Dallas, Short-Termism, supra note 291 , at 307 . To facilitate policy changes in target firms, lead hedge funds typically acquire up to $10 \%$ of a target firm's shares by the time they disclose their ownership of shares by filing their Schedule 13D - required to be filed within the ten-day window after acquiring $5 \%$ of the target firm's shares. Coffee, Jr. \& Palia, supra note 147, at 562-63. They are aided in their efforts to influence target management by other hedge funds - the "wolf pack" - that also acquire target firm shares before the lead hedge fund files its Schedule 13D. Id. at $550-51$. Assuming the hedge funds acquire $33 \frac{1}{3} \%$ of the target firm's shares and $15 \%$ to $20 \%$ of the shares are not voted at the meeting, which is typical, the hedge funds only need to persuade the holders of $7 \%$ to $10 \%$ of the target firm's shares to vote 
Hedge funds benefit from their activism. ${ }^{376}$ Studies' findings on the consequences of this activism on target firms' stock prices are mixed, ${ }^{377}$ although it is clear that a significant number of target firms suffer longterm negative consequences from it. ${ }^{378}$ Even if successful in opposing hedge funds' insurgencies, targets of activism often feel pressure to adopt the strategies proposed by the hedge funds. For example, Pershing Square Capital Management (Pershing), a hedge fund, aligned with Valeant Pharmaceutical International (Valeant) in 2014 to control Allergan, Inc. (Allergan) ${ }^{379}$ Valeant's business model was to acquire pharmaceutical firms with established products, reduce their R\&D programs, and maximize its profits by selling and developing already established products. ${ }^{380}$ Valeant announced that if it was successful in taking over Allergan, it would decrease Allergan's R\&D by $69 \%$, focus its R\&D on expanding the uses of Allergan's Botox products, and fire $20 \%$ of Allergan's employees. ${ }^{381}$ When it became apparent that the proxy contest for control of Allergan was likely to succeed, Allergan's managers reacted by adopting the hedge funds' objectives, although on a smaller scale. ${ }^{382}$ This response by target firms is not atypical. Over the 2009 to 2013 period hedge fund targets that were not taken over nevertheless decreased their R\&D — as a percentage of sales — by more than $50 \%{ }^{383}$

Firms not targeted by hedge fund activism are also affected by it because they wish to avoid becoming a target. ${ }^{384}$ For example, after Allergan's experience, other pharmaceutical firms, in what has been referred to as a trend, began to spin off non-core divisions and reexamined their R\&D

for their board nominees. Id. at 568. Thus, short-term shareholders are able to obtain de facto control of major corporations "only to exit on average within a year after their appearance." Id. at 604. Hedge fund activist campaigns have increased dramatically. See id. at 554-56.

376. Wolf pack hedge funds actually incur very little risk by purchasing shares during the ten-day window and selling shortly thereafter, making millions in the process. Id. at 547, 56566.

377. See id. at 581-93 (providing an objective, comprehensive, and current analysis of hedge fund studies); see also YVAN AlLAIRE \& FrAN OIS DAUPHIN, “ACTIVIST" HEDGE

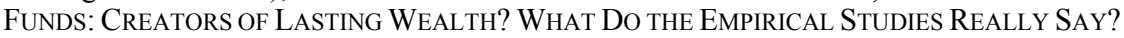
14 (July 2014), http://www.wlrk.com/docs/IGOPP Article Template2014 Activism EN v6.pdf [https://perma.cc/8G8Y-5ELW] (providing a comprehensive discussion of hedge fund studies, concluding that these studies "have not demonstrated that activist hedge funds, per se, create lasting, long-term value").

378. See Coffee, Jr. \& Palia, supra note 147, at 584, 586.

379. Id. at 577 .

380. Id. at 577-58.

381. Id. at 578 .

382. See id. (reporting that Valeant decreased its R\&D by $13 \%$ from its historical rate of $16 \%$ to $17 \%$ and cut its workforce by $13 \%$ ).

383. Id. at 574

384. See id. at 579 . 
programs. ${ }^{385}$ The threat of hedge fund activism is ever-present and effective. In 2014 hedge funds won $73 \%$ of their campaigns to acquire board seats, and $44 \%$ of targeted firms' CEOs were replaced within eighteen months. ${ }^{386}$

Also, hedge funds do not just target "laggards," as agency theorists would have predicted. ${ }^{387}$ For example, DuPont was the target of hedge fund activism in $2015 .{ }^{388}$ It was highly successful and had been a profitable, innovative firm for many years. ${ }^{389}$ Fortunately, long-term shareholders in this instance pushed back. ${ }^{390}$ Nevertheless, DuPont sold off a major division, reorganized its $R \& D$ programs, and distributed $\$ 9$ billion to its shareholders. ${ }^{391}$

\section{Large Payouts to Shareholders: A Change in Orientation from "Retain and Reinvest" to "Downsize and Distribute"?}

Large payouts to shareholders in the form of dividends and stock repurchases are often sought by hedge funds and also used by managers as a means to boost stock prices to impress the stock market. ${ }^{392}$ As previously mentioned, agency theorists promoted payouts as a positive managerial disciplining tool and in furtherance of the shareholder value maximization conception. ${ }^{393}$ Payouts are viewed as an investment-limiting strategy designed to discourage managers from engaging in self-interested empire building. ${ }^{394}$ By returning internally generated funds to shareholders, managers must persuade external capital markets of the value of the investments they wish to make. However, payouts have some negative consequences. A firm that must return to capital markets to fund investments involves transaction costs and introduces a level

\footnotetext{
385. Id.

386. Id. at 556 .

387. See id. at 582 .

388. See id. at 579 .

389. See id.

390. Id. at 581 (naming BlackRock Inc., State Street Global Advisors, and the Vanguard Group as the supportive shareholders).

391. Id. at 579.

392. See William Lazonick, Profits Without Prosperity, HARV. Bus. ReV. (Sept. 2014), https://hbr.org/2014/09/profits-without-prosperity [https://perma.cc/Z648-FDL7].

393. See supra text accompanying note 155 .

394. See Coffee, Jr. \& Palia, supra note 147, at 550. Compensation based on a firm's size was believed to encourage managerial empire building. However, managers are no longer compensated on that basis. Dobbin \& Zorn, supra note 151, at 183.
} 
of uncertainty that may shorten the time horizon of firm investments. ${ }^{395}$ Moreover, financing investments through debt, although requiring a serious assessment by managers of whether the firm is likely to be able to pay off the debt, introduces risk during economic downturns. ${ }^{396}$ This risk may discourage firm investments, particularly long-term investments, and also deprives firms of the ability to take advantages of business opportunities that may arise in periods of economic down cycles. In addition, some scholars claim that rather than disciplining managers, payouts to shareholders through stock buybacks have allowed managers to manipulate market prices to enhance the value of their stock options that remain a significant portion of managerial compensation. ${ }^{397}$

Some scholars have argued that increasing payout to financial markets through dividends, interest payments, and stock buyouts - in essence what they refer to as a change in policy from "retain and invest" to "downsize and distribute" - are crowding out real investments by firms. ${ }^{398}$ While an in-depth review of this subject is outside the scope of this Article, there are some dramatic facts that raise serious concerns. For example, one study shows that from mid-2009 through 2013, firms borrowed nearly $\$ 900$ billion, invested only $\$ 400$ billion, and paid out $\$ 740$ billion to shareholders. ${ }^{399}$ Another study shows that from 2003 to 2013 S\&P 500 Index firms increased their spending on stock repurchases and dividends from $18 \%$ of operating cash flow to $36 \%$ of operating cash flow and decreased their investments on plant and equipment during this same period. ${ }^{400}$ The cuts in investments were found to be more dramatic for targets of hedge fund activism. ${ }^{401}$

395. Orhangazi, supra note 125 , at 870,881 . It is also problematic when managers are not able to convey effectively to markets their private information about firm prospects.

396. Dobbin \& Jung, supra note 155, at 47.

397. See, e.g., Paul Hribar et al., Stock Repurchases as an Earnings Management Device, 41 J. ACCT. ECON. 3, 25 (2006); Lazonick \& O'Sullivan, supra note 142, at 16.

398. See, e.g., Orhangazi, supra note 125 , at 866-68, 882-83.

399. J.W. MASON, Disgorge THE CASH: THE Disconnect BETWEEN BorRowing AND INVESTMENT 3 (Feb. 25, 2015), http://rooseveltinstitute.org/wp-content/uploads/2015/09/ Disgorge-the-Cash.pdf[https://perma.cc/64XB-R5KR]. "In the 1960s and 1970s, an additional dollar of earnings or borrowing was associated with about a [forty]-cent increase in investment. Since the 1980 s, less than [ten] cents of each borrowed dollar is invested." Id.

400. Vipal Monga et al., Firms Send More Cash Back to Shareholders, Wall St. J., May 27, 2015, at A1; see also Lazonick \& O'Sullivan, supra note 142, at 22-25 (noting the use of "retain and reinvest" strategies by firms in the $1950 \mathrm{~s}, 60 \mathrm{~s}$, and $70 \mathrm{~s}$ and increasing payouts by firms in subsequent decades); Maxwell Murphy, Bond-Funded Dividends, Buybacks Draw Skeptics, WALl ST. J. (June 16, 2015, 3:24 AM), http://blogs.wsj.com/cfo/ 2015/06/16/bond-funded-dividends-buybacks-draw-skeptics/ (discussing the practice of firms in using debt proceeds on stock buybacks and dividends). Total financial payments by firms as a percentage of profits before tax increased from the 1980 s to 2003 . Orhangazi, supra note 125 , at 867 fig. 3 .

401. Monga et al., supra note 400. It is possible that firms are simply making high profits due to technological advances, cost cutting strategies, and/or market power resulting 


\section{Financial Firms}

Managers of financial firms were responsible for the financial crisis by failing to follow prudent financial practices as they sought short-term profits, legitimated by the shareholder value maximization conception. ${ }^{402}$ They did not adequately manage risk or consider the impact of their actions on their clients or the long-term viability of their firms. ${ }^{403}$ Their actions reverberated throughout the economy affecting firms, individuals, governmental bodies, and others. ${ }^{404}$

A number of practices that contributed to the financial crisis continue today and create an unstable, uncertain business environment. ${ }^{405}$ For instance, financial firms engage in "naked" derivative transactions. ${ }^{406}$ These transactions are not bona-fide hedging - insurance-like - transactions but are simply bets or gambles. ${ }^{407}$ The Dodd-Frank Wall Street Reform and Consumer Protection Act of 2010 - the "Dodd-Frank Act"-passed in the wake of the financial crisis, arguably has not dealt adequately with this kind of derivative transaction. ${ }^{408}$ Naked derivatives are a source of profits for financial firms

from industry-concentration levels and have sufficient funds to cover their capital investments and R\&D needs before returning large sums to shareholders. It is also possible that short-term financial players are squeezing every last penny out of firms, leaving them at risk in the long run. Another change in the corporate landscape is that firms are not only more closely tied to financial markets because of their payouts to financial markets, but they may be more closely tied to financial markets because of their reliance on financial markets for sources of income. There is evidence of this during the 1980s and 90s. Greta R. Krippner, The Financialization of the American Economy, 3 Socio-Econ. REv. 173, 199 (2005). To the extent that firms increase their reliance on financial markets for sources of income, financial markets become a matter of preoccupation at board meeting and nonfinancial firms come to resemble financial firms as they become less dependent on productive activities and place greater importance on financial markets. See Engelbert Stockhammer, Financialisation and the Slowdown of Accumulation, 28 CAMBRIDGE J. ECON. 719, 71920, 724, 738-39 (2004).

402. See Dallas, Short-Termism, supra note 291, at 310-20.

403. See id. at 278-81, 294-95.

404. See id. at 290-93.

405. See id. at 286-87, 338 .

406. These transactions are sometimes referred to as "speculative" derivatives. Id. at 338 .

407. Id. at 286, 338; E. Glen Weyl \& Eric A. Posner, A Proposal for Limiting Speculation on Derivatives: An FDA for Financial Innovation 1 (Coase-Sandor Inst. for Law \& Econ., Working Paper No. 594, 2012), http://chicagounbound.uchicago.edu/cgi/viewcontent.cgi? article $=1012 \&$ context $=$ law_and_economics.

408. Dodd-Frank Wall Street Reform and Consumer Protection Act of 2010, Pub. L. No. 111-203, 124 Stat. 1376 (codified as amended in scattered sections of the U.S.C.); see Dallas, Short-Termism, supra note 291, at 338-40. 
but create risks for non-financial firms and the financial system as a whole. ${ }^{409}$ Ironically, these risks also provide profitable opportunities for financial firms to sell financial products to non-financial firms to manage the risks the financial firms themselves have created.

Financial firms continue to engage in unethical and illegal behavior. An example includes the actions of banks in rigging the LIBOR rate that determines the cost of trillions of dollars of credit card debt, mortgages, and other loans. This behavior resulted in fines for banks and criminal convictions for bank traders in 2015 and 2016. ${ }^{410}$ Additionally, Citibank, JPMorgan Chase, Barclay, and the Royal Bank of Scotland, major financial institutions, were convicted of federal crimes in a scheme to manipulate the value of the world's currencies in 2015. ${ }^{411}$ These criminal actions increase risks facing non-financial firms that may affect their willingness to take risks by innovating and planning for the long term. This behavior by financial firms suggests they have not given sufficient attention to changing their culture focused on shareholder value maximization that contributed to the financial crisis. ${ }^{412}$

Also, potentially troubling is that financial firms have become major players in commerce, thus not limiting their activities to finance. Deregulation since the 1980s that culminated in the Gramm-Leach-Bliley Act of 1999 gradually allowed banks to enter global commodities markets. ${ }^{413}$ Moreover,

409. Dallas, Short-Termism, supra note 291, at 286 (noting that by 2007, CDS contracts were worth twice as much as the nonprime mortgages outstanding).

410. See James McBride, Understanding the Libor Scandal, COUNCIL ON FOREIGN REL. (Oct. 12, 2016), http://www.cfr.org/united-kingdom/understanding-libor-scandal/p28729 [https://perma.cc/Z9EH-9SGM]; Margot Patrick \& Josie Cox, Three Former Barclays Traders Convicted in Libor-Rigging Case, WALL ST. J. (July 4, 2016, 9:57 AM), http://www.wsj.com/ articles/three-former-barclays-traders-convicted-in-libor-rigging-case-1467640635; Randall Smith, Two Former Traders Found Guilty in Libor Manipulation Case, N.Y. TIMEs (Nov. 5, 2015), https://www.nytimes.com/2015/11/06/business/dealbook/two-former-traders-foundguilty-in-libor-manipulation-case.html.

411. Michael Corkery \& Ben Protess, Rigging of Foreign Exchange Market Makes Felons of Top Banks, N.Y. TimES (May 20, 2015), http://www.nytimes.com/2015/05/21/ business/dealbook/5-big-banks-to-pay-billions-and-plead-guilty-in-currency-and-interestrate-cases.html? r=0; Karen Freifeld et al., Global Banks Admit Guilt in Forex Probe, Fined Nearly \$6 Billion, REUTERS (May 20, 2015, 10:35 PM), http://www.reuters.com/article/ us-banks-forex-settlement-idUSKBN0O50CQ20150520 [https://perma.cc/TV5D-3DYJ].

412. See Dallas, Short-Termism, supra note 291, at 316-20.

413. Financial Services Modernization Act of 1999 (Gramm-Leach-Bliley Act), Pub. L. No. 106-102, 113 Stat. 1338 (codified as amended in scattered sections of 12 and 15 U.S.C.); see Saule T. Omarova, The Merchants of Wall Street: Banking, Commerce, and Commodities, 98 MinN. L. REv. 265, 279-80, 285-88 (2013); Marcus Stanley, The Goldman Sachs Guide to Manipulating Commodities: How Big Wall Street Banks Are Gaming Commodities Markets, U.S. News (July 24, 2013, 4:50 PM), https://www.usnews.com/ opinion/blogs/economic-intelligence/2013/07/24/how-goldman-sachs-and-wall-streetmanipulate-alumnimum-and-other-commodities; Reid B. Stevens \& Jeffery Y. Zhang, Slipping Through the Cracks: Detecting Manipulation in Regional Commodity Markets 3 (Dec. 21, 2016) (unpublished manuscript), https://www.federalreserve.gov/SECRS/2016/ 
between 2002 and 2012, the Federal Reserve weakened the regulations of bank holding companies by interpreting their ownership and trading of physical commodities as "complementary" to their financial activities as commodity derivative traders. ${ }^{414}$ Morgan Stanley and Goldman Sachs, bank holding companies, have become "key players in the production, processing, transportation, storage, and trading of a wide range of physical commodities." 415 This creates risks for non-financial firms in terms of access to vital products and the possibility of speculative trading that could raise the price of products they need. ${ }^{416}$ It also creates unfair advantages to financial firms over producers and other operators because of informational and financial advantages they enjoy. ${ }^{417}$ Among other potential consequences, financial firms' exposures in both financial and physical commodities markets may also contribute to systemic risk of the financial system. ${ }^{418}$

A situation that received a great deal of publicity involved non-financial firms' access to raw materials. It was claimed that Coca-Cola Company's ability to obtain aluminum cans for its soft drinks was affected by Goldman Sachs' practices in limiting the supply of aluminum from its subsidiary's warehouses. ${ }^{419}$ By way of background, since 1999 there has been an increase in the trading of aluminum on financial markets and the amounts held by financial firms. ${ }^{420}$ From 2010 to 2014, financial firms substantially increased their aluminum inventories, with one firm, Goldman Sachs, at one point holding over one-half of the total U.S. aluminum supply. ${ }^{421}$ The regional

December/20161223/R-1547/R-1547_122216_131636_398498405419_1.pdf [https://perma.cc/ LZH8-4VTA].

414. Omarova, supra note 413, at 288-89.

415. Id. at 312-18, 318-24.

416. See id. at 347-49.

417. U.S. Senate, Permanent Subcomm. on Investigations, 113 Th Cong., Wall Street Bank Involvement with Physical Commodities 34-36 (2014) [hereinafter SENATE REPORT]; see Omarova, supra note 413, at 303, 341-46 (discussing, among other issues, the informational advantages of financial firms and the substantial resources they possess, including the implicit governmental subsidy to bail them out, which allows them to obtain credit more cheaply from third parties than other firms); Stanley, supra note 413.

418. SENATE REPORT, supra note 417, at 40-41; Omarova, supra note 413, at 271, $344,354-55$.

419. Stevens \& Zhang, supra note 413, at 3; David Kocieniewski, A Shuffle of Aluminum, But to Banks, Pure Gold, N.Y. TIMES (July 20, 2013), http://www.nytimes.com/2013/07/21/ business/a-shuffle-of-aluminum-but-to-banks-pure-gold.html?pagewanted=all; Stanley, supra note 413.

420. Stevens \& Zhang, supra note 413 , at $4-5 \&$ fig. 2 .

421. Id. at 3 . 
aluminum price rose during this period. ${ }^{422}$ A study of this period found the price increase was likely due to manipulation by Goldman Sachs in the aluminum storage market, which was also the conclusion of a Senate report. ${ }^{423}$ The study concluded that, "despite the regulatory framework introduced by the [Dodd-Frank Act], regional physical commodity markets remain vulnerable to manipulation. Financial institutions like bank holding companies and hedge funds can manipulate regional markets and cause a large, sustained impact on regional prices." 424 In 2016, the Board of Governors of the Federal Reserve System proposed stricter rules regarding bank holding companies' holdings of physical commodities. ${ }^{425}$

\section{Inequality}

Lastly, the disparity of wealth in the United States has increased dramatically since the emergence of the shareholder value maximization conception of corporate governance. Increases in stock prices disproportionately benefit the wealthy. ${ }^{426}$ This is not surprising. In terms of stock ownership, the top $10 \%$ of the population owns $81 \%$ of the stock while the bottom $90 \%$ own only $19 \% .427$ Thus, adopting the shareholder value goal means that firms and their boards, executives, and employees should take all actions, within the bounds of the law, to benefit mainly $10 \%$ of the population. The economic fallout on the remaining $90 \%$ is of less importance to firms

422. Id. at 3, 4 fig. 1

423. SENATE REPORT, supra note 417 , at 226; Stevens \& Zhang, supra note 413 , at $7-9$.

424. Stevens \& Zhang, supra note 413 , at 42.

425. See Risk-Based Capital and Other Regulatory Requirements for Activities of Financial Holding Companies Related to Physical Commodities and Risk-Based Capital Requirements for Merchant Banking Investments, Regulations Q and Y, 81 Fed. Reg. 67220,67220 (proposed Sept. 30, 2016) (to be codified at 12 C.F.R. pts. 217 225). The comment period on the proposed rules was extended to February 20, 2017. Risk-Based Capital and Other Regulatory Requirements for Activities of Financial Holding Companies Related to Physical Commodities and Risk-Based Capital Requirements for Merchant Banking Investments, Regulations Q and Y, 81 Fed. Reg. 94276, 94276 (Dec. 23, 2016).

426. Michael T. Owyang \& Hannah Shell, Talking Stock: Income Inequality and the Stock Market, ECON. SYNOPSES (Fed. Reserve Bank of St. Louis, St. Louis, Mo.), Apr. 29, 2016, at 1, https://files.stlouisfed.org/files/htdocs/publications/economic-synopses/201604-29/taking-stock-income-inequality-and-the-stock-market.pdf [https://perma.cc/3BU2C9YM]; cf. Gomory \& Sylla, supra note 115, at 113 ("[W]e have seen only small returns to most Americans over the last thirty years, the period in which the shareholder view overtook the stakeholder view. Almost all the gains from increased productivity ... have gone to the top economic tier.").

427. Robert Frank, The Stock Gap: American Stock Holdings at 18-Year Low, CNBC (Sept. 8, 2014, 11:12 AM), https://www.cnbc.com/2014/09/08/the-stock-gap-americanstock-holdings-at-18-year-low.html [https://perma.cc/GX7D-UV8E]. 
following the shareholder value maximization conception of corporate governance.

Some scholars believe the shareholder value maximization conception has shifted the strategic orientation of firms in such a way that they are more likely to downsize by cutting the size of their workforces. ${ }^{428}$ They seek to cut their costs, increase their profit margins, and meet the quarterly earnings expectations of security analysts. ${ }^{429}$ This is facilitated, among other means, by a decline in the power of unions and technological changes that permit tasks to be performed with fewer workers. ${ }^{430}$ Moreover, the shorttermism of financial firms seeking to satisfy their investors contributed to the financial crisis that had an adverse impact on workers. Significantly, one study found that the major cause of manufacturing job loss during the 2007 to 2014 period was the financial crisis. ${ }^{431}$ A short-term focus is believed by some to hinder the adoption of long-term business strategies by firms that would connect economic value creation with social value. ${ }^{432}$

428. Batt \& Appelbaum, supra note 111, at 18-20; Jung, supra note 187, at 1335-36; see Lazonick \& O'Sullivan, supra note 142, at 18-20; see also Davis, The Rise and Fall of Finance, supra note 251 , at 28 ("The orientation toward share price led corporations to restructure toward a flexible original equipment manufacturer (OEM) or network model of corporate organization ....").

429. See supra Sections III.C, IV.A.2.

430. Batt \& Appelbaum, supra note 111, at 1, 20.

431. Robert E. Scott, Manufacturing Job Loss: Trade, Not Productivity, Is the Culprit, IsSUE BRIEF (Econ. Pol'y Inst., Wash., D.C.) Aug. 11, 2015, at 2 \& fig.A, 6, http://www.epi.org/ files/2015/ib402-manufacturing-job-loss.pdf [https://perma.cc/D9MV-ZN8W]. This study also found that from 2000 to 2006 the major causes of the U.S. trade deficit were currency manipulation and subsidies by foreign nations that contributed to the national trade deficit. Id. at 7. Currency manipulation enables foreign nations to suppress the value of their currencies to make their industries' products cheaper than U.S. products. Subsidies also make their products cheaper and thus increase foreign nations' exports. The U.S. steel industry is currently under siege with having to compete with cheaper foreign products supported by currency manipulation and foreign subsidies. Thomas J. Gibson \& Chuck Schmitt, The Crisis Facing the U.S. Steel Industry, CNN (Mar. 23, 2016, 11:31 PM), http://www.cnn.com/ 2016/03/23/opinions/american-steel-industry-gibson-schmitt/ [https://perma.cc/YU5E-8SEE]. China has pursued mercantilist policies. Gomory \& Sylla, supra note 115, at 110-11. There is "no economic theory [that] says that persisting in free trade is the best response to mercantilism." Id. at 114 .

432. See Michael E. Porter \& Mark R. Kramer, Creating Shared Value: How To Reinvent Capitalism-And Unleash a Wave of Innovation and Growth, HARV. BuS. REV., Jan.-Feb. 2011, at 1, 4, 8, https://ncg.org/sites/default/files/resources/HarvardBusinessReview_Creating Shared_Value.pdf [https://perma.cc/4NER-8CSF]. 
The U.S. worker is faced today with a difficult job environment. The proportion of jobs that have low wages has increased because of outsourcing. ${ }^{43}$ Outsourcing is designed to decrease the costs of the outsourcing firm, placing pressure on subcontractors to decrease their prices. As a result, the subcontractors' employees may suffer decreased wages and benefits. ${ }^{434}$ Vertical disintegration through global supply chains, that is, "offshoring," also reduces the availability of jobs in the United States as primary firms vertically disintegrate, sending U.S. jobs to low-wage countries. ${ }^{435}$

Additionally, the service sector has emerged as the largest source of U.S. jobs. ${ }^{436}$ The largest employers have changed from companies such as General Motors to companies like Wal-Mart. ${ }^{437}$ Lower wages and benefits often accompany this change. ${ }^{438}$ Notably, many service jobs are eligible for offshoring to low-wage countries. ${ }^{439}$ Since the 1990 s, this is true for high-skill jobs as well as low-skilled jobs. ${ }^{440}$ Thus, the acquisition of a college degree or greater skills does not necessarily guarantee a good job in the United States. While downsizing of employees was counter to developed norms in the managerial era, it has become in the shareholder value maximization era "business-as-usual.".441

Although cost cutting is ubiquitous in U.S. business decision making, decisions involving executive compensation have been the exception. ${ }^{442}$ Executive compensation has increased dramatically. ${ }^{443}$ Firms' practices have changed with CEOs receiving high equity-based compensation to encourage them to maximize shareholder value. ${ }^{444}$ One study found that high CEO

433. Batt \& Appelbaum, supra note 111, at 21.

434. Id.

435. Id.

436. DeP'T For Prof'L EMPS., The Service Sector: Projections And Current Stats

1 (2011), http://dpeaflcio.org/wp-content/uploads/Service-Sector-2011.pdf [https://perma.cc/

WT55-P75G]; see Davis, The Rise and Fall of Finance, supra note 251, at 28.

437. Davis, The Rise and Fall of Finance, supra note 251, at 28, 29 tbl.1.

438. Id. at 30-31. Today's largest employers also often provide limited opportunities for career advancement. See id. at 30,35.

439. See id. at 39.

440. See Alan Tonelson, The Race to the Bottom: Why a Worldwide Worker Surplus and Uncontrolled Free Trade Are Sinking American Living Standards 99-100, 112-13, 115-16 (2000) (providing examples of high-end jobs being offshored); see Davis, The Rise and Fall of Finance, supra note 251, at 39 (stating that "any task that can be sent over the Internet" is vulnerable to offshoring).

441. Jung, supra note 187, at 1345.

442. See Lawrence Mishel \& Alyssa Davis, Top CEOs Make 300 Times More Than Typical Workers: Pay Growth Surpasses Stock Gains and Wage Growth of Top 0.1 Percent, ISSUE BRIEF (Econ. Pol'y Inst., Wash., D.C.) June 21, 2015, at 1-2, http://www.epi.org/files/ 2015/top-ceos-make-300-times-more-than-typical-workers.pdf [https://perma.cc/9W4FMNK7].

443. Id.

444. See supra Section IV.A.3. 
compensation contributed to inequality. ${ }^{445}$ Moreover, as previously discussed, high CEO compensation has been associated with the callous treatment of employees. ${ }^{46}$ Also, downsizing is more frequent when a significant portion of CEO compensation consists of stock options, that is, when CEOs are more focused on stock prices. ${ }^{447}$

Firm downsizing may have long-term negative consequences for the firms in U.S. markets. For example, it may eventually have an impact on U.S. consumer demand for products. ${ }^{448}$ While the decreasing share of firm profits going to workers in past years has been offset to some degree by consumer debt and workers, and their family members, working longer hours, there are limits to these strategies for creating consumer demand. ${ }^{449}$ Also, as previously noted, consumer demand is not shored up by broad-based substantial capital ownership by U.S. consumers. ${ }^{450}$

Additionally, the weakened connections of firms with the wellbeing of the communities in which they sell and produce their products will most likely have negative long-term firm consequences. ${ }^{451}$ Societal problems as well as firm externalities pose internal costs for firms. ${ }^{452}$ Firms rely on "public assets and supportive environments." ${ }^{453}$ For example, important to firms are healthy, educated workers; transportation facilities, such as ports, roads and bridges; energy sources; raw materials that have not been depleted; and a broader business environment providing ancillary services to support their activities. ${ }^{454}$ They also rely on political systems to provide security for their workers and assets and provide them flexibility to operate. Firms that do not consider as central to their business strategies the societal value they create, and instead seek short-term profits, undermine their businesses in the long run and also their legitimacy. ${ }^{455}$ Distrust of business is high in the United States and it has generated considerable dissatisfaction. ${ }^{456}$ The plight

445. See Jonathan L. Willis \& Julie Wroblewski, What Happened to the Gains from Strong Productivity Growth?, 2007 FED. RES. BANK KAN. ECON. REV. 5, 20.

446. See supra text accompanying note 336.

447. See supra text accompanying note 334 .

448. See Business in America, supra note 278.

449. It also increases the power of the U.S. financial sector, on which many people have become dependent.

450. See supra text accompanying note 427 .

451. See Porter \& Kramer, supra note 432, at 6.

452. Id. at 5,8

453. Id. at 6 .

454. Id. at 5,12 .

455. Id. at $15-17$.

456. See id. at 4,17 . 
of U.S. workers may trigger political instability. It has recently caused polarization among U.S. citizens, and the anger and dissatisfaction of U.S. workers, as exhibited in the popularity of Bernie Sanders and Donald Trump. ${ }^{457}$

\section{B. The Sustainability Conception of "Good" Corporate Governance}

There is considerable support for the emergence of a new conception of corporate governance. ${ }^{458}$ The current conception has metamorphosed into a system that is increasingly under fire. ${ }^{459}$ It has been heavily criticized and, some have argued, inconsistent with what agency theorists sought to achieve. ${ }^{460}$ It has resulted in managers adopting short-term strategies to meet the quarterly earnings expectation of security analysts and hedge fund activists. ${ }^{461}$ Strategies such as excessive downsizing and cost cutting and large payouts to shareholders appear to pose threats to the long-term ability of firms to contribute to human wellbeing. ${ }^{462}$ In addition, unethical and illegal practices have become pervasive. ${ }^{463}$ The economy generally has been

457. See James Surowiecki, Economic Populism at the Primaries, New Yorker (Feb. 22, 2016), http://www.newyorker.com/magazine/2016/02/22/trump-sanders-and-the-americanworker [https://perma.cc/S7U4-5HSJ].

458. See, e.g., Lynn Stout, The Shareholder Value Myth: How Putting Shareholders First HARMS InVESTORS, CORPORATIONS, AND THE Public passim (2012) (rejecting the firm goal of shareholder value maximization); Gomory \& Sylla, supra note 115 , at 114-16 (discussing how the shareholder value maximization conception has misaligned the interests of global corporations and the United States and proposing that profit maximization be replaced with U.S. value-added maximization); Steve Denning, The Dumbest Ideas in the World: Maximizing Shareholder Value, ForBES (Nov. 28, 2011, 1:19 PM), https:// www.forbes.com/sites/stevedenning/2011/11/28/maximizing-shareholder-value-the-dumbestidea-in-the-world/2/\#71a76601e387 (arguing for a focus on consumers and an abandonment of the shareholder expectation model that rewards gaming the financial system rather than creating real value); see also Dallas \& Barry, supra note 350, at 544-45 nn.3-5 (referencing numerous research reports, policy statements, recommendations, and scholarly articles expressing concern about short-termism and the fixation of managers on meeting analysts' earnings projections).

459. See generally Gomory \& Sylla, supra note 115 (questioning whether the shift to shareholder value maximization has been beneficial to the United States); Michael Magill et al., A Critique of Shareholder Value Maximization 37 (Swiss Fin. Inst., Research Paper No. 13-16, Mar. 26, 2013), http://ssrn.com/abstract=2246797 (providing a model showing that large firms that engage in profit maximization underinvest and that they must take into account the "external effects" of their decisions "on consumers and workers ... to achieve a Pareto optimal outcome"); Denning, supra note 458 (criticizing managerial incentives to focus on stock market prices).

460. See Dobbin \& Jung, supra note 155, at 30-31; Denning, supra note 458; Michael C. Jensen, Value Maximization and Stakeholder Theory, HARV. Bus. SCH. WORKING KNOWLEDGE (July 24, 2000), http://hbswk.hbs.edu/item/value-maximization-and-stakeholder-theory [https://perma.cc/US47-724L] (arguing in favor of enlightened stakeholder theory, which rejects prioritizing shareholder interests in favor of maximizing total long-term firm value).

461. See supra Sections IV.A.2.7.

462. See supra Sections IV.A.8-9.

463. See supra Section IV.A.2.4.6.9. 
harmed by the increased risks of such behaviors that were realized in such disasters as the corporate scandals of the early 2000s and the financial crisis of 2007 to $2009 .{ }^{464}$ Additionally, financial firms have increased the risks of nonfinancial firms by engaging in opportunistic behaviors and speculative trading in derivatives, currency markets, and physical commodities, all legitimated by maximizing profits for their shareholders. ${ }^{465}$ These behaviors have arguably severed the relationship between profits and social value.

In this connection a sustainability conception of corporate governance has gained considerable traction in recent years among scholars, investors, and business leaders. ${ }^{466}$ This sustainability conception encourages firms to pursue long-term value and focus on the interests of their stakeholders. ${ }^{467}$ It is more consistent with effective corporate governance from a societal perspective than the shareholder value maximization conception. It is based on the recognition that firms affect many people, not just shareholders. ${ }^{468}$ While this view is critical of the shareholder value maximization conception, long-term shareholders are expected in most cases to benefit from the

\footnotetext{
464. See supra Sections IV.A.6.9.

465. See supra Section IV.A.7.9.

466. See, e.g., Dominic Barton et al., Re-Imagining Capitalism for the Long Term:
} Situating the Volume, in RE-Imagining CAPITALism 1, 11 (Dominic Barton et al. eds., 2016) (reimaging capitalism "as evolving from a narrowly defined shareholder capitalism to a focus on long-term value creation and prioritization of a broader set of stakeholders"); Robert G. Eccles et al., The Impact of Corporate Sustainability on Organizational Processes and Performance, 60 MGMT. SCI. 2835, 2853 (2014) (finding "during the 18-year period [studied], high sustainability companies outperform the low sustainability ones in terms of both stock market and accounting measures while the market did not actually expect the outperformance"); David Millon, Two Models of Corporate Social Responsibility, 46 WAKE Forest L. REV. 523, 530-33 (2011) [hereinafter Millon, Two Models of Corporate Social Responsibility] (noting that his sustainability model views stakeholder concerns as "essential to the viability and success of the firm" and shareholder value); Judd F. Sneirson, The Sustainable Corporation and Shareholder Profits, 46 WAKE FOREST L. REV. 541, 543 (2011) ("A sustainable business should ... pursue financial goals while at the same time treading as lightly as possible on the earth and its natural resources, supporting the business's employees and local communities, and developing products, services, and technologies that contribute to larger societal efforts to live more sustainability."); see infra text accompanying note 513.

467. See Eccles et al., supra note 466, at 2843-45. This Article conflates the constituency and sustainability models discussed by Millon, Two Models of Corporate Social Responsibility, supra note 466, at 524-25. Thus, this Article does not adopt the sustainability model as proposed by Millon. See infra text accompanying notes 490-504 (discussing the importance of stakeholder rights and engagement); see also note 479 (discussing the importance of business environment to conceptions of corporate governance).

468. Millon, Shareholder Social Responsibility, supra note 290, at 919-20. 
sustainability conception. ${ }^{469}$ That is, the wellbeing of firms in the long term depends to a large degree on the wellbeing of all stakeholders. ${ }^{470}$ While study findings are mixed, one recent study - distinguished by measuring the financial performance of firms over a long period of time- - found that high-sustainability companies outperformed their low-sustainability counterparts in both stock and accounting returns. ${ }^{471}$ High sustainability firms have a "culture of sustainability" and adopt policies and practices attending to the needs of the environment, employees, customers, suppliers, and other stakeholders. ${ }^{472}$ Other studies have also demonstrated the profitability of sustainable businesses. ${ }^{473}$ The shared value perspective endorses the sustainability view and encourages firms to "creat[e] [economic] value in a way that also creates value for society by addressing its needs and challenges. ${ }^{\circ 74}$ This requires firms to integrate into the core of their strategic decision making the interests of stakeholders. ${ }^{475}$

Contrary to the views of some, there are no corporate law impediments to firms adopting the sustainability conception of corporate governance. ${ }^{476}$ Courts grant corporate boards of directors substantial discretion under the business judgment rule in making business decisions on behalf of their firms. ${ }^{477}$ Moreover, corporate law regarding corporate purpose has not materially changed over the years. ${ }^{478}$ Note that in the past under managerialism U.S. firms did not operate in accordance with the shareholder value maximization conception. ${ }^{479}$

469. Millon, Two Models of Corporate Social Responsibility, supra note 466, at 530-33. While the sustainability conception proposed in this Article often coincides with seeking long-term shareholder value, it is measured by a positive long-term relationship between firm behavior and social value.

470. Id.

471. Eccles et al., supra note 466, at 2850-51.

472. See id. at 2843-45.

473. Sneirson, supra note 466, at 543 n. 10.

474. Porter \& Kramer, supra note 432, at 4.

475. Id. (criticizing the "social responsibility' mind-set" of some firms that view "societal issues [as] at the periphery, not the core" of strategic decision making).

476. See, e.g., STOUT, supra note 458, at 10; Lyman Johnson \& David Millon, Corporate Law After Hobby Lobby, 70 Bus. Law. 1, 10-15 (2014). The Revlon Doctrine is an arguable exception in the context of sale of control transactions, although recent case law has weakened this exception. See Lyman Johnson \& Robert Ricca, The Dwindling of Revlon, 71 WASH. \& LEE L. REV. 167, 193-95 (2014) [hereinafter Johnson \& Ricca, The Dwindling of Revlon].

477. See 1 Am. Law Inst., Principles of CoRporate Governance: ANAlysis AND RECOMMENDATIONS $§ 4.01 \mathrm{cmt}$. d (1994).

478. The only significant change has been the Revlon Doctrine that has been substantially weakened. See Johnson \& Ricca, The Dwindling of Revlon, supra note 476, passim.

479. See supra text accompanying notes 110-18. The sustainability conception has some features in common with managerial capitalism, where profit was one firm goal among others. See supra text accompanying note 13 . However, the "countervailing" forces that operated under managerialism do not operate today. Gomory \& Sylla, supra note 115, at 108. During 
There is reason for optimism because businesses can be seen to adopt the sustainability conception of good corporate governance through some of their policies. Firms, for example, have acknowledged the importance of corporate social responsibility (CSR) by adopting internal codes of conduct. ${ }^{480}$ Moreover, many firms voluntarily provide sustainability reports that disclose their CSR practices, with a majority of these reports being certified by third parties. ${ }^{481}$ GM provided the first public CSR report in 1972. ${ }^{482}$ By 2013, 93\% of Fortune Global 250 firms provided CSR reports, of which $59 \%$ were independently verified. ${ }^{483}$ Also, a number of companies have become B Corporations. ${ }^{484}$ These corporations are required to meet certain performance standards relating to governance, workers, community, and the environment. ${ }^{485}$ New corporate forms have also emerged,

the earlier period, shareholders were mainly passive, and many employees had unions to represent them. Id. at 116. Today, shareholders have a great deal of power, and unions have very little power. $I d$. at 108 . Without the creation of countervailing power favoring employees and other stakeholders, it is unlikely that the sustainability conception will operate as intended in practice. This is why various methods to give more weight to employee interests are discussed in this Part. See infra text accompanying notes 490-504. Moreover, it is important to point out that there has been a learning process in response to a changing business and technological environment that will influence firms - that pursue profit among other goals - to adopt different business structures and strategies than in the past.

480. JAMES K. JACKSON, CONG. RESEARCH SERV., RS20803, CODES OF CONDUCT FOR MulTinATIONAL CORPORATIONS: AN OVERVIEW 6-7 (2013), http://digitalcommons.ilr.cornell.edu/ cgi/viewcontent.cgi?article $=2115 \&$ context $=$ key_workplace.

481. KPMG INT'L, KPMG INTERNATIONAL SURVEY OF CORPORATE RESPONSIBILITY REPORTING 2013, at 22, 33 (2013), https://assets.kpmg.com/content/dam/kpmg/pdf/2015/ 08/kpmg-survey-of-corporate-responsibility-reporting-2013.pdf [https://perma.cc/4MZLPRKC] (referring to third-party certification as "external assurance"); Davis et al., Political Agency, supra note 246, at 104, 112-13; Sneirson, supra note 466, at 558 n.81. "Triple-bottom line" reporting focuses on people, planet, and profit consistent with the Global Reporting Initiative Sustainability Reporting Guidelines. Suntae Kim et al., Why Companies Are Becoming B Corporations, HARV. Bus. REV. (June 17, 2016), https://hbr.org/2016/06/why-companiesare-becoming-b-corporations [https://perma.cc/T4CG-MJCW]; see GLOB. REPORTING INITIATIVE, G4 SUSTAINABILITY REPORTING GUIDELINES 3 (2016), https://www.globalreporting.org/ resourcelibrary/GRIG4-Part1-Reporting-Principles-and-Standard-Disclosures.pdf [https:// perma.cc/5RVW-XE9U]. See generally GLOB. REPORTING INITIATIVE, THE EXTERNAL ASSURANCE OF SUSTAINABILITY REPORTING (2013), https://www.globalreporting.org/resourcelibrary/ GRI-Assurance.pdf [https://perma.cc/NU2U-QCKJ].

482. David Malone \& Robin W. Roberts, Public Interest Reports as a Medium for Corporate Disclosure: The Case of General Motors, 15 J. Bus. ETHICs 759, 760 (1996); Davis et al., Political Agency, supra note 246, at 112.

483. KPMG INT'L, supra note 481, at 12, 22.

484. Kim et al., supra note 481 .

485. Id. 
such as benefit corporations and flexible purpose corporations that require firms to serve general or special public benefits. ${ }^{486}$ A trend in the direction of corporate social responsibility is also seen with young entrepreneurs, such as the founders of Kickstarter who decided to forego selling out their firm for large sums in favor of operating their business in a hybrid form that takes into account public benefits. ${ }^{487}$ Reflecting the importance of sustainability is the Dow Jones Sustainability Index that assesses firm policies and practices that contribute to sustainability. ${ }^{488}$

There are a number of steps that can be taken to further the sustainability conception. Coordinating the steps and determining priorities requires focused efforts by business leaders, scholars, politicians, and others, exemplified by such groups as the Aspen Institute and FCLT Global. ${ }^{489}$ One step is to

486. See William H. Clark, JR. et Al., Benefit CorP., White Paper: The NeED

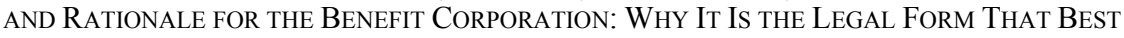
AdDRESSES the NeEdS OF SOCIAL ENTREPRENEURS, INVESTORS, AND, Ultimately, the Public 1, 16, App. C 5-6 (Jan. 18, 2013), http://benefitcorp.net/sites/default/files/Benefit Corporation_White_Paper.pdf [https://perma.cc/FPM8-QMQP]; Ian Kanig, Note, Sustainable Capitalism Through the Benefit Corporation: Enforcing the Procedural Duty of Consideration to Protect Non-Shareholder Interests, 64 Hastings L.J. 863, 890-92 (2013); Ellen Berrey, How Many Benefit Corporations Are There? 1 (May 5, 2015) (unpublished manuscript), https://papers.ssrn.com/sol3/papers.cfm?abstract_id=2602781. See generally Lyman Johnson, Pluralism in Corporate Form: Corporate Law and Benefit Corps., 25 REGENT U. L. REV. 269 (2013) (providing a thoughtful analysis of benefit corporations in the context of corporate law doctrine and theory). Professor Davis has suggested other forms of businesses, such as cooperatives and mutuals. Davis, supra note 191, at 136-37.

487. Mike Isaac \& David Gelles, Kickstarter Focuses Its Mission on Altruism over Profit, N.Y. TIMES (Sept. 20, 2015), http://www.nytimes.com/2015/09/21/technology/kick starters-altruistic-vision-profits-as-the-means-not-the-mission.html?_r=0.

488. ROBECOSAM, MEASURING INTANGIBLES: ROBECOSAM's CORPORATE SUSTAINABILITY ASSESSMENT METHODOLOGY 13 (2017), http://www.robecosam.com/images/Measuring Intangibles_CSA_methodology.pdf [https://perma.cc/F9E7-BBFF].

489. See ASPEN INST., AMERICAN ProsPerity ProJeCt: A NONPARTISAN FramewOrK FOR LONG-TERM INVESTMENT 2, 4 (2016), https://assets.aspeninstitute.org/content/uploads/ 2017/01/American-Prosperity-Project_Policy-Framework_FINAL-1.3.17.pdf [https://perma.cc/ VT26-5R8Z]; Dominic BARTON ET AL., FCLT Glö., Rising to the Challenge of SHORT-TERMISM 1, 11-12 (2016), http://www.fcltglobal.org/docs/default-source/defaultdocument-library/fclt-global-rising-to-the-challenge.pdf?sfvrsn=0 [https://perma.cc/MXE97GMD]; Rebecca Darr \& Tim Koller, How To Build an Alliance Against Corporate ShortTermism, MCKINSEY \& Co. (Jan. 2017), http://www.mckinsey.com/Business-Functions/ Strategy-and-Corporate-Finance/Our-Insights/How-to-build-an-alliance-against-corporateshort-termism [https://perma.cc/BFL2-2NN3]; see also JOHN KAY, U.K. DEP'T FOR BUS. INNOVATION \& SKILLS, THE KAY REVIEW OF UK EQUITY MARKETS AND LONG-TERM DECISION MAKING: FINAL REPORT 9, 87-88 (2012), https://www.gov.uk/government/uploads/system/ uploads/attachment_data/file/253454/bis-12-917-kay-review-of-equity-markets-final-report.pdf [https://perma.cc/9H6T-WXME]. 
mandate social disclosures and require independent certification of them. ${ }^{490}$ Requiring these disclosures is a powerful tool. For example, one study found that firms that did not voluntarily disclose the number of workers they employed by geographical segment were firms that were offshoring jobs and therefore anticipated worker and public backlash if they disclosed that information. ${ }^{491}$ Moreover, having firms disclose information of relevance to employees, such as the percentage of employees covered by their pension plans and the amounts firms contribute to them on their employees' behalf, would enhance the likelihood that firms would take employee interests more into account. ${ }^{492}$ Professor Norman Bowie some years ago set out instructions for ethical decision making by firms: (1) "consider the interests of all stakeholders in making decisions," (2) get actual "input from all affected stakeholders," (3) do not give one stakeholder absolute priority for all decisions, as is the case for shareholder value maximization, and (4) establish just procedures for accomplishing these requirements. ${ }^{493}$ Firms are encouraged to take into account the interests of all stakeholders in making decisions when social disclosures are mandated. ${ }^{494}$

Rarely do corporate scholars argue that shareholders are owners of firms, although this term is often used in the popular press and in court decisions. For example, in analyzing eleven tests of ownership, only two tests were unequivocally met by shareholders of firms. ${ }^{495}$ Moreover, while it has been argued under the residual rights theory that only shareholders

490. See supra text accompanying note 483. See generally Dallas, Short-Termism, supra note 291, at 324-35 (reexamining disclosures to take into account the long-term value of firms).

491. Anne Beatty \& Scott Liao, What Do Multinationals' Disclosure of the Number of U.S. Versus Foreign Employees Tell Us? 3-5, 10 (Mar. 19, 2012) (unpublished manuscript), http://www8.gsb.columbia.edu/rtfiles/accounting/ANNE.BEATTY.pdf [https://perma.cc/ 2PBE-6YCQ].

492. See Jacoby, supra note 115 , at $485-86$.

493. Norman E. Bowie, The Firm as a Moral Community, in Morality, Rationality, AND EfFiciency: New Perspectives on Socio-Economics 169, 176 (Richard M. Coughlin ed., 1991).

494. The federal securities laws were based on the philosophy of Justice D. Brandeis, who stated, "Publicity is justly commended as a remedy for social and industrial diseases. Sunlight is said to be the best of disinfectants; electric light the most efficient policeman." Justice Louis D. Brandeis, BRANDEIS UNIV., http://www.brandeis.edu/legacyfund/bio.html [https://perma.cc/8FH4-GYEB].

495. John Kay \& Aubrey Silberston, Corporate Governance, in 2 PeRSPECTIVES ON Company Law 49, 53-55 (Fiona Macmillan Patfield ed., 1997) (discussing A.M. Honoré, Ownership, in OXFORD ESSAYS IN JURISPRUDENCE 107, 113, 116-21, 123, 126 (A.G. Guest ed., 1961)). 
have residual interests in firms, employees also have residual rights and are more concerned with the survival of their firms than diversified shareholders. $^{496}$ There is therefore theoretical support for Professor Bowie's requirements for ethical decision making that involve getting input from affected stakeholders and establishing just procedures for doing so.

Some strategies proposed or adopted in other developed nations potentially go further than Professor Bowie's prescriptions by providing for participation by stakeholders in firm decision making, although some strategies are limited to allowing stakeholders to provide input. Some scholars and politicians have proposed having employees on corporate boards, employee committees, or some other method for employee engagement. ${ }^{497}$ This is commonplace in Germany, which has a system of employee co-determination that includes employee representatives on the supervisory board and internal firm works councils. ${ }^{498}$ Moreover, many European nations have works councils that institutionalize communications among managers and employee representatives. ${ }^{499}$ These ethical firm decision making mechanisms provide some countervailing balance to the unrestrained influence of shareholders within firms present in the current era and therefore make more likely the realization of the objectives of the sustainability conception. ${ }^{500}$

However, a sustainability approach does not require changes in governance structures or new forms of businesses. Firms may adopt stakeholder engagement practices that facilitate managers' understanding of the interests of stakeholders. ${ }^{501}$ They may make investments in managing stakeholder relationships and integrate sustainability concerns into managerial and

496. See Kent Greenfield, The Place of Workers in Corporate Law, 39 B.C. L. REV. 283, 305, 308-09 (1998).

497. UK DEPT. FOR BUS., ENERGY \& INDUSTRIAL StRATEGy, CORPORATE GOVERNANCE REFORM -GREEN PAPER 38-42, Nov. 2016 (exploring options for reform to strengthen the voice of stakeholders in large UK firms); Jacoby, supra note 115, at 486; Marleen A. O'Connor, The Human Capital Era: Reconceptualizing Corporate Law To Facilitate Labor-Management Cooperation, 78 CoRNELl L. REV. 899, 962-63 (1993); see Dallas, Two Models of Corporate Governance, supra note 12, at 109-13.

498. Bennet Berger \& Elena Vaccarino, Codetermination in Germany - A Role Model for the UK and the US?, BRUEGEL BLOG (Oct. 12, 2016), http://bruegel.org/2016/10/ codetermination-in-germany-a-role-model-for-the-uk-and-the-us/; see also Lynne L. Dallas, Proposals for Reform of Corporate Boards of Directors: The Dual Board and Board Ombudsperson, 54 WASH. \& LEE L. REV. 91, 96 n.8 (1997) [hereinafter Dallas, The Dual Board] (proposing a dual board structure in the United States different from the dual board structure in Germany).

499. See Employee Involvement - European Works Councils, EUROPEAN COMMISSION, http://ec.europa.eu/social/main.jsp?catId=707\&langId=en\&intPageId=211 [https://perma.cc/ 6G29-2XZL] (providing information on works councils in the European Union).

500. See Millon, Shareholder Social Responsibility, supra note 290, at 919-20. See generally RoBERT ReICH, SAVING CAPITALISM: FOR THE MANY, NOT THE FEW 167-92 (2015) (discussing the decline of countervailing power and measures to restore it).

501. Eccles et al., supra note 466, at 2840. 
lower-level decision-making, including making sustainability concerns relevant to compensation determinations. ${ }^{502}$ Firms become more successful in achieving sustainability objectives when the board and top executives value and take responsibility for the implementation of their firm's sustainability policies and practices. ${ }^{503}$ Feedback from stakeholders and an interested public are encouraged by firm disclosures of their sustainability policies and practices. ${ }^{504}$

The main criticism of a sustainability approach is that it is believed to give managers too much flexibility in making business decisions. ${ }^{505}$ They may pursue their own self-interest under the guise of serving selected stakeholder interests. Without the single goal of shareholder wealth maximization, they are believed to become unaccountable. However, directors already have broad discretion under the business judgment rule, and the goal of shareholder value is sufficiently ambiguous to encompass most business decisions. ${ }^{506}$ Moreover, persons often become more accountable by pursuing multiple objectives, depending on our normative premises of what we would like them to achieve. For example, professors have goals of excellence in teaching, scholarship, and service. There are conflicts among these goals and they must make tradeoffs among them. However, professors are no less accountable because of them. ${ }^{507}$ Also, consider the importance of multiple goals in the following situation. A mother has three children. Would we say she should maximize the welfare of one of her three children? In fact, we would say that she would be irresponsible and acting unfairly to pursue one goal in these circumstances in which her children, who possess conflicting interests, rely on her decision making. The issue is not feasibility or accountability, but our normative premises. Thus, the main issue of corporate governance is whether the firm is effective, that is, the degree to which it is successful in reaching desired results.

As this Article has shown, the shareholder value maximization conception has contributed to short-term behaviors by managers. ${ }^{508}$ This behavior is inconsistent with the sustainability conception of corporate governance.

502. Id. at $2836,2839,2841$.

503. Id. at 2839 .

504. Id. at 2841

505. LynNe L. Dallas, LaW And Public Policy: A Socioeconomic ApProach 518

(2005) [hereinafter Dallas, LaW AND Public Policy]; Khurana, supra note 148, at 321.

506. DALLAS, LAW AND PUBLIC POLICY, supra note 505, at 519.

507. Id. at 518 .

508. See Millon, Shareholder Social Responsibility, supra note 290, at 911-12. 
It is detrimental to workers, long-term shareholders, and society in general. Destroying the environment, excessive firing of employees, and producing defective products may increase firm profits in the short term, but they do not enhance human wellbeing in the long-term. ${ }^{509}$ A recent study utilizing financial measures of short-termism found that short-termism negatively impacted long-term shareholders. ${ }^{510}$ It found U.S. firms that manage more for the long-term than their peers substantially outperformed them and provided more jobs. ${ }^{511}$ Estimations from this data suggest that if all U.S. public firms performed similarly, five million additional jobs would have been created from 2001 to 2015, and the U.S. GDP would have increased by $\$ 1$ trillion. ${ }^{512}$ Numerous business and financial leaders, business commentators, academics, and politicians are in agreement on the problematic nature of short-term firm decision making. ${ }^{513}$ They have expressed their concern that firms are not operating to enhance long-term performance and that this is detrimental to society. ${ }^{514}$ These include such luminaries as Hillary Clinton, Joe Biden, and Larry Fink, the CEO of BlackRock, the world's largest institutional investment firm. ${ }^{515}$

In addition to the steps mentioned above concerning social disclosures and employee engagement, a number of other steps can be taken to support

509. See id. at 911-12, 915, 924-25.

510. Dominic Barton et al., Finally, Evidence That Managing for the Long Term Pays Off, HARV. Bus. ReV. (Feb. 9, 2017), https://hbr.org/2017/02/finally-proof-thatmanaging-for-the-long-term-pays-off [https://perma.cc/4Q58-YRZ3].

511. Id. A long-term perspective also facilitates a stakeholder approach because in the short term, tradeoffs are made among the interests of stakeholders. Eccles et al., supra note 466, at 2841-42; see also Millon, Shareholder Social Responsibility, supra note 290, at 911-12, 927 (discussing how short-termism is an "impediment" to corporate social responsibility).

512. Barton et al., supra note 510.

513. Dallas \& Barry, supra note 350, at 544-45. "Short-termism is the subject of important research reports, policy statements, and recommendations from the business community." Dallas, Short-Termism, supra note 291, at 269. See also House OF COMMONS, Bus. INNOvaTiON \& Skills Comm., The Kay Review of UK Equity Markets and Long-Term Decision MAKING: THIRD REPORT OF SESSION 2013-14 (2013), https://publications.parliament.uk/ $\mathrm{pa} / \mathrm{cm} 201314 / \mathrm{cmselect} / \mathrm{cmbis} / 603 / 603 . \mathrm{pdf}$ [https://perma.cc/3QA4-XSRF] (reporting on short-termism in UK equity markets and making proposals for reform).

514. Id.

515. Joe Biden, How Short-Termism Saps the Economy: Paying CEOs So Much in Stocks Puts Their Focus on the Share Price Instead of Building for the Long Run, WALL ST. J. (Sept. 27, 2016, 7:14 PM), http://www.wsj.com/articles/how-short-termism-sapsthe-economy-1475018087; William A. Galston, Clinton Gets It Right on Short-Termism: Too Many CEOs Ignore Long-Term Performance, to the Economy's Harm, WALL ST. J. (July 29, 2015, 8:41 AM), http://www.wsj.com/articles/hillary-gets-it-right-on-shorttermism-1438124913; Matt Turner, Here Is the Letter the World's Largest Investor, BlackRock CEO Larry Fink, Just Sent to CEOs Everywhere, Bus. InSIDER (Feb. 2, 2016, 8:03 AM), http://www.businessinsider.com/blackrock-ceo-larry-fink-letter-to-sp-500-ceos-2016-2. 
the sustainability conception. ${ }^{516}$ There is evidence that managers can attract long-term shareholders to their firms by adopting sustainability policies. ${ }^{517}$ Long-term investments by shareholders can also be encouraged by such methods as imposing a securities transaction tax and increasing capital gains taxes for short-term stock turnovers. ${ }^{518}$ Additionally, mutual funds may be required to include trading costs in the expense ratio disclosed to their clients. ${ }^{519}$ In one fund, for example, the reported expense ratio was $1.94 \%$, but had trading costs been included, it would have been $5.55 \% .{ }^{520}$ The compensation of fund managers can also be based on long-term results rather than on quarterly earnings, referred to as the "quarter sprint." 521 This may occur as mutual fund investors become less inclined to redeem their funds on the basis of short-term results because they become aware of the trading costs associated with their redemptions. Additionally, efforts can be made to encourage the Securities and Exchange Commission to support the development of the long-term stock exchange proposed to benefit Silicon Valley firms. ${ }^{522}$

To diminish hedge fund activism, a number of measures have been recommended to limit the ability of hedge fund groups - "wolf packs"to engage in short-term activism. ${ }^{523} \mathrm{~A}$ more aggressive suggestion than

516. Some concerted efforts have been made to evaluate and propose steps that should be taken. See, e.g., ASPEN INST., supra note 489.

517. Eccles et al., supra note 466, at 2842 (finding that high sustainability companies are significantly more likely to attract long-term shareholders). One study finds that although short-termism may be fueled by pressure from transient shareholders, it is equally true that they are attracted to companies that have executives with short-term orientations and shortterm cultures. Brochet et al., supra note 350, at 28 (finding that short-term shareholders are attracted to firms with short-term orientations and short-term cultures).

518. Dallas, Short-Termism, supra note 291, at 348-50; Jacoby, supra note 115, at 484.

519. Dallas, Short-Termism, supra note 291, at 329-30; see Jeff Schwartz, Reconceptualizing Investment Management Regulation, 16 GEO. MASON L. REV. 521, 546-47 (2009).

520. Henry T.C. Hu, The New Portfolio Society, SEC Mutual Fund Disclosure, and the Public Corporation Model, 60 Bus. LAw. 1303, 1326 (2005).

521. Dallas, Short-Termism, supra note 291, at 319.

522. See Ellen Huet \& Brad Stone, Silicon Valley's Audacious Plan To Create a New Stock Exchange, BLOOMBERG (June 12, 2016, 4:00 PM), https:/www.bloomberg.com/news/articles/ 2016-06-12/silicon-valley-s-audacious-plan-to-create-a-new-stock-exchange [https://perma.cc/ 26SG-KRCY].

523. See Coffee, Jr. \& Palia, supra note 147, at 595-601 (making recommendations such as to decrease the ten-day window that delays the disclosure of target share acquisitions by hedge funds, to modify insider-trading regulations to cover tips by the lead hedge fund to wolf pack members, and to provide an expanded definition of "group" to include wolf pack members). 
these measures is to prohibit short-term shareholders from engaging in proxy contests. ${ }^{524}$ Another is to require that activists own a 3\% interest in the target for two years after substantially successful activist interventions. A less aggressive suggestion would apply certain provisions of firm proxy access bylaws to all campaigns for board seats. For example, typically, bylaw proxy access is limited to shareholders who have held $3 \%$ of the firm's shares for three years prior to their proposing director nominees. ${ }^{525}$ High penalties and serious enforcement would aid in assuring compliance with these measures.

Other suggestions involve the use of time-phased voting stock, stock that receives greater amounts of dividends the longer it is owned, and warrants granted to shareholders that would become exercisable when their shares have been held for a specified duration. ${ }^{526}$ Changing managerial compensation is another avenue for consideration. ${ }^{527}$ Firms are urged to utilize deferred compensation arrangements for their top executives to counter the pressures for short-termism. ${ }^{528}$ However, without other steps being taken, changing managerial compensation will not be very effective if boards of directors rely on input from short-term shareholders in deciding whether to retain them. There is also the need for long-term metrics for evaluating firm performance and their disclosure to investors and efforts to create long-term firm cultures. ${ }^{529}$ I refer the reader to my article on short-termism and the vast literature on short-termism for additional suggestions. ${ }^{530}$

Finally, nonfinancial firms will benefit from the regulation of financial firms. Uncertainties created by market manipulations and excesses of financial firms make long-term investments by non-financial firms less likely to occur. ${ }^{531}$ The financial crisis has shown the dangers of unregulated financial products and the potential for systemic risk. Additionally, our markets

524. See supra note 348 (discussing short-term shareholder classifications).

525. Memorandum from Sullivan \& Cromwell LLP on Proxy Access: Developments in Market Practices 1, 3 (Apr. 8, 2016), https://www.sullcrom.com/siteFiles/Publications/ SC Publication_Proxy_Access_Developments_in_Market_Practice.pdf [https://perma.cc/D48C$\mathrm{BE} 5 \mathrm{X}]$.

526. See generally Patrick Bolton \& Frederic Samama, Loyalty-Shares: Rewarding Long-Term Investors, 25 J. APPLIED CORP. FIN. 86, 88, 95 (2013) (discussing the use of dividends and warrants to encourage long-term time horizons); Dallas \& Barry, supra note 350 (exploring the pros and cons of time-phased voting).

527. See Dallas, Short-Termism, supra note 291, at 358-61.

528. See id. at $277,358,361$.

529. BARTON ET AL., supra note 489, at 13; Dallas, Short-Termism, supra note 291, at 324-28. Firm cultures have an impact on whether managers will "delay a new project and sacrifice some value" to meet quarterly earnings expectations. BARTON ET AL., supra note 489 , at 8 .

530. See generally Dallas, Short-Termism, supra note 291.

531. See discussion supra Section IV.A.9. 
are made more vulnerable with massive gambles in naked derivatives, and the control of commodities markets by financial firms. ${ }^{532}$

Society in general will benefit from the sustainability conception. It will support a focus on the wellbeing of workers, consumers, and other stakeholders, including long-term shareholders. Rather than non-financial firms serving financial firms, the positions of these firms would become reversed. The sustainability conception would also require a broader understanding of corporate governance that would encompass the operation and regulation of financial markets, ${ }^{533}$ global trade, ${ }^{534}$ and industrial concentration as these factors impact firms, workers, consumers, and society in general. ${ }^{535}$

\section{CONCLUSION}

What I have learned from looking back over the course of history is there is always hope for change when an existing, seemingly immutable conception has taken hold. As people observe and experience the negative implications of a conception, they seek changes. These changes are influenced by the writings of academics, forward-looking business leaders, investors, and politicians responding to public outrage through regulatory changes. In the process, we see the emergence of new conceptions of corporate governance. These changes influence corporate cultures and the strategies pursued by businesses. To those operating in the business environment, what currently exists often seems right and inevitable - the only way to do business - but that is not the case. The current conception is the result of a confluence of a number of different factors that are interpreted by people trying to make sense of their environment and prosper. Unfortunately, the conception ultimately adopted may have unintended consequences, negatively impacting the economy and people's lives, and call for further evolution.

I observe that the writings of economists, judges, and scholars have had a large impact on conceptions of corporate governance over the years. Therefore, I have reason for optimism as I read progressive corporate law scholarship. However, the current situation calls for even greater engagement of these scholars in public discourse than in the past in a political environment of rapid regulatory changes. I encourage them to distill their ideas into

532. See discussion supra Section IV.A.9.

533. See supra Section IV.A.9 and text accompanying note 431 .

534. See supra note 431.

535. See supra text accompanying notes $280-82$. 
formats accessible to public officials and the interested public. I also believe that it is necessary for scholars to broaden their areas of expertise to encompass an expanded notion of corporate governance and thus effectively contribute to the resolution of the complex problems facing society. 